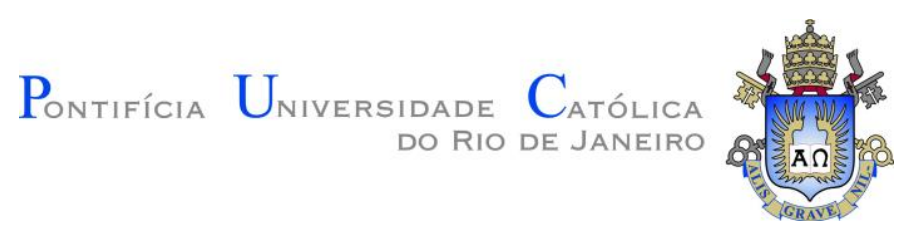

Roberta Calcado Vinhaes

\title{
O manejo de estados regressivos em análise: uma experiência intersubjetiva
}

Dissertação de Mestrado Dissertação apresentada como requisito parcial para obtenção do grau de Mestre pelo Programa de PósGraduação em Psicologia (Psicologia Clínica) do Departamento de Psicologia da PUC-Rio.

Orientador: Carlos Augusto Peixoto Junior

Rio de Janeiro,

Março de 2021 


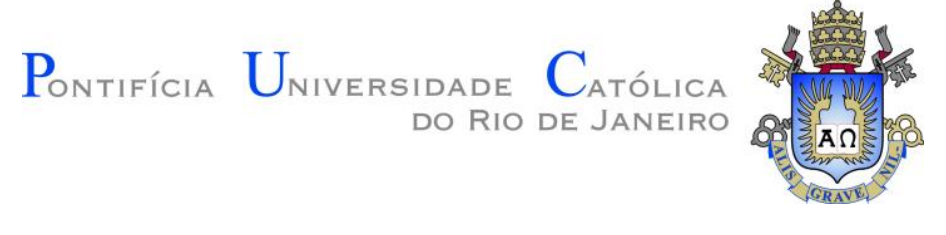

Roberta Calcado Vinhaes

\section{O manejo de estados regressivos em análise: uma experiência intersubjetiva}

Dissertação apresentada como requisito parcial para obtenção do grau de Mestre pelo Programa de Pós-Graduação em Psicologia (Psicologia Clínica) da PUC-Rio. Aprovada pela Comissão Examinadora abaixo.

Prof. Carlos Augusto Peixoto Junior Orientador

Departamento de Psicologia - PUC-Rio

Profa. Daniela Romão Barbuto Dias Departamento de Psicologia - PUC-Rio

Profa. Josaida de Oliveira Gondar UFRJ

Rio de Janeiro, 05 de março de 2021. 
Todos os direitos reservados. É proibida a reprodução total ou parcial do trabalho sem autorização da universidade, do autor e do orientador.

\section{Roberta Calcado Vinhaes}

Graduou-se em Psicologia em 2018 pela PUC-Rio. Bolsista CAPES durante o mestrado (2019 e 2020). Membro do NEPECC/UFRJ. Atua como psicóloga clínica desde 2019.

Ficha Catalográfica

Vinhaes, Roberta Calcado

O manejo de estados regressivos em análise : uma experiência intersubjetiva / Roberta Calcado Vinhaes ; orientador: Carlos Augusto Peixoto Junior. - 2021. 173 f. ; $30 \mathrm{~cm}$

Dissertação (mestrado)-Pontifícia Universidade Católica do Rio de Janeiro, Departamento de Psicologia, 2021.

Inclui bibliografia

1. Psicologia - Teses. 2. Regressão. 3. Manejo. 4. Contratransferência. 5. Clínica psicanalítica. I. Peixoto Junior, Carlos Augusto. II. Pontifícia Universidade Católica do Rio de Janeiro. Departamento de Psicologia. III. Título.

CDD: 150 


\section{Agradecimentos}

Ao meu orientador, Carlos Augusto Peixoto Junior, pelo respeito ao meu ritmo de trabalho e pelas contribuições sempre precisas e instigantes que alimentam minha curiosidade.

Ao Departamento do Programa de Pós-graduação em Psicologia da PUC-Rio, pelos auxílios concedidos, sem os quais este trabalho não seria possível.

A CAPES, o presente trabalho foi realizado com apoio da Coordenação de Aperfeiçoamento de Pessoal de Nível Superior - Brasil (CAPES) - Código de Financiamento 001.

Ao grupo do NEPECC pela riqueza da troca constante.

A Daniela, por ser mestre, professora, amiga. Por ser mãe em todas essas funções.

A Jô Gondar, por carinhosamente aceitar o convite de participar desta comissão examinadora.

A Ana Thereza, por tudo que já me emprestou de si para que eu possa ser.

Caminho porque criamos pernas.

A Teresa Pinheiro, pelas apostas nesses primeiros passos clínicos.

A Joana Camelier, por já me receber com tanto estímulo e acolhimento.

A Júlia, pelo tanto que dividimos. Dividir lar com alguém, dividir lar com alguém em uma pandemia. Dividir alimento. Dividir ar. Dividir ar contagioso. Se contagiar conjuntamente, continuamente. Dividir vida. 
Ao Filipe, por explicar a diferença entre "ir de encontro a" e "ir ao encontro de", mas sobretudo pela força e sinceridade do nosso encontro. Vou ao seu encontro.

A minha mãe, por estar perto mesmo longe. Tão perto que já sabe que suficiente é o melhor que pode ser. Obrigada por me dar tudo que tem para dar. Ao meu pai, pela gentileza infinita naquilo que acredita. Por acreditar em mim e incansavelmente incentivar cada etapa. Ao meu irmão pelo exemplo constante de dedicação e seriedade.

Aos meus avós Vera e Cacau, colegas da área da sáude, a quem tenho tanto como exemplo.

Aos meus avós Carlos e Zoraide, cuja bondade sinto sempre perto.

As minhas amigas Carol, Tatá, Laura, Malu, Mavi, por serem pouso seguro nos momentos difíceis.

Aos meus colegas da psicologia, de estudos, de encontros, já que por sorte são também amigos.

Aos amigos companheiros de consultório, que mantém a poltrona quentinha.

Aos meus alunos-colegas-amigos, pela confiança que depositam em mim que tanto me faz crescer.

Aos meus pacientes, por tantas criações. 


\section{Resumo}

Vinhaes, Roberta Calcado; Peixoto Junior, Carlos Augusto. O manejo de estados regressivos em análise: uma experiência intersubjetiva. Rio de Janeiro, 2021. 173p. Dissertação de Mestrado - Departamento de Psicologia, Pontifícia Universidade Católica do Rio de Janeiro.

O presente trabalho tem como objetivo investigar as contradições e possibilidades clínicas inauguradas pelo conceito de regressão. Partiremos das postulações freudianas, nas quais abordaremos a regressão em seu aspecto intrapsíquico, sendo associada aos processos oníricos e de formação sintomática, para depois seguirmos com autores que consideramos relacionais. Dentre eles, o primeiro a ser abordado é o húngaro Sándor Ferenczi, quem primeiro apresenta a regressão enquanto fenômeno clínico e destaca a importância dos processos internos do analista na relação terapêutica. Em sua esteira, seguiremos com Donald Winnicott e Michael Balint. Veremos nas contribuições dos dois autores uma descrição mais detalhada e assertiva sobre os estados regressivos. Em todos os três autores, na medida em que tratamos do fenômeno da regressão, estaremos cotejando também as ideias de contratransferência e as teorias acerca da constituição subjetiva. Em uma última parte do trabalho faremos uma aproximação da clínica contemporânea em uma tentativa de descrever como o conceito da regressão é um que exprime inovações importantes para se pensar a clínica hoje. Veremos como as discussões acerca do conceito ao longo da história da psicanálise contemplam aspectos essenciais para a clínica como o campo transferencial, o corpo e o manejo.

\section{Palavras-chaves}

Regressão; manejo, clínica psicanalítica; contratransferência 


\section{Abstract}

Vinhaes, Roberta Calcado; Peixoto Junior, Carlos Augusto (Advisor). The Handling of Regressive Phenomena in Analysis: an Intersubjective Experience. Rio de Janeiro, 2021. 173p. Dissertação de Mestrado Departamento de Psicologia, Pontifícia Universidade Católica do Rio de Janeiro.

The present work has as main objective investigate the contradictions as well as clinical possibilities initiated by the notion of regression. We'll start off from the freudian postulations, through which we'll approach the idea of regression in its intrapsychic aspect associating it with the process of dream and symptom formation. We'll then proceed with authors by us considered relational. Among them, the first to be addressed will be the Hungarian Sándor Ferenczi, who is the first to introduce the idea of regression as a clinical phenomena and to highlight the importance of the analyst's internal world in the therapeutic relationship. Following Ferenczi, we'll regard the works of Donald Winnicott e Michael Balint. Through their contributions we'll bring to light a more detailed and assertive description of the regressive states. However, in all threes authors, as we approach the phenomena of regression, we'll be also examining the idea of countertransference and the theories regarding the constitution of subjectivity. In the last part of the work we'll propose an approximation to contemporary psychoanalysis in an attempt to describe how the concept of regression contains important innovations for clinical references today. We'll progress by presenting how the discussions about such phenomena through history of psychoanalysis contemplate pivotal clinical aspects such as transference, body and clinical handling.

\section{Keywords}

Regression; clinical handling, psychoanalytic clinic; countertransference 


\section{Sumário}

1. Introdução

2. A regressão como movimento intrapsíquico em Freud

2.1 Regressão na primeira tópica: sintomas presentes e suas origens passadas

2.2 Regressão na segunda tópica: um retorno ao inanimado

2.3 Técnica psicanalítica clássica: uma transferência unilateral

3. Regressão na obra de Sándor Ferenczi: a possibilidade de uma dimensão terapêutica

3.1 A regressão "bioanalítica" 49

3.2 O desenvolvimento do ego na teoria ferencziana 53

3.3 A técnica ativa: uma ampliação da técnica clássica 63

3.4 A elasticidade como princípio técnico 72

3.5 Clivagem enquanto defesa, regressão enquanto manejo 79

4. Balint e Winnicott: criação do novo a partir da experiência regressiva

4.1 Uma reformulação da ideia de narcisismo 87

4.2 As três áreas da mente e as diferentes relações de objeto 95

4.3 O manejo das regressões 103

4.4 Desenvolvimento emocional primitivo 113

$\begin{array}{ll}4.5 \mathrm{O} \text { ego e o self } & 120\end{array}$

4.6 Regressões em análise: a função materna do analista 124

5. Clínica contemporânea: o que se vive além da palavra 132

5.1 O lugar do analista, do paciente e da psicanálise 133 
5.2 A contratransferência como eixo técnico

$5.3 \mathrm{O}$ que sabe um corpo? 146

5.4 Busca por contorno através do manejo 149

5.5 Estados regredidos: uma experiência sensorial 153

6. Considerações finais 161

7. Referências bibliográficas 
A maior parte dos acontecimentos ocorrem num espaço que nenhuma palavra nunca pisou.

Rainer Maria Rilke 


\section{Introdução}

A noção de regressão é uma bastante controversa no meio psicanalítico. Não apenas abre para diferentes compreensões como marca olhares decididamente distintos. Embora não seja um conceito amplamente estudado, ou mesmo mencionado em sua condição de conceito, o mesmo carrega definições conflitantes, se tornando tema delicado. Talvez, por isso, pouco abordado enquanto objeto de discussão.

Como de costume no vocabulário científico a palavra usada para designar um fenômeno específico traz como herança seu significado da linguagem corriqueira. Quando pensamos no ato de regredir somos levados a uma noção espaço-temporal linear que descreve o movimento que vai de um ponto B a um ponto A, ou seja, que retorna a uma origem. Veremos como esta definição servirá para alguns autores mas não para outros na medida em que entramos em formas não-lineares de concepção da experiência subjetiva. Entretanto, a ideia de retorno será sempre, de uma ou outra maneira, preservada. Mudará o que retorna e, sobretudo, as consequências ou o potencial desse movimento. Balint já discutia, em 1968, a amplitude deste conceito:

Clinicamente isso significa que fenômenos sugerindo uma regressão serão observados de tempos em tempos durante um tratamento analítico. Existem, entretanto, percepções amplamente divergentes dentre os analistas no que diz respeito a frequência, o significado e a importância desse fenômeno. As percepções variam também no que diz respeito até onde o fenômeno é causado pelo paciente, isto é, pela sua personalidade, pela natureza de seu sofrimento, ou pela técnica particular do analista. Em minha opinião, ambos analista e paciente participam mas não é simples distinguir quanto é de cada um. Qualquer descrição que isole exclusivamente um dos participantes provavelmente será falha em sua essência. (Balint, 1968/1992, p.81)

O que esse trecho parece evidenciar é que o conceito, além de exigir uma exploração detalhada na medida em que sua concepção varia segundo diversos aspectos, necessariamente envolve o par analítico, ou seja, não pode ser acessado por um viés exclusivamente intrapsíquico. Isso, é claro, já é um posicionamento. 
Veremos, porém, como na teoria freudiana somos introduzidos também a um aspecto intrapsíquico da regressão. Entretanto, no decorrer da psicanálise o conceito foi sendo ampliado ao ser percebido enquanto vivência clínica de potencial terapêutico. Trata-se de um conceito inicialmente teórico que vai sendo destrinchado em um acontecimento clínico e, ao sê-lo, convoca um olhar especial para a relação analítica e o campo transferencial.

Tendo em vista essas primeira considerações iremos abordar a problemática da regressão e, como consequência, o debate sobre o campo transferencial a partir dos seguintes quatro autores: Freud, Ferenczi, Balint e Winnicott. Após uma apresentação cuidadosa da teoria de cada um deles, apresentaremos também uma elaboração acerca da importância dos conceitos tratados para a clínica contemporânea. É nesse último capítulo, quando tentamos ilustrar clinicamente o porquê da regressão ser um conceito de relevância para a psicanálise hoje, que se torna mais evidente o objetivo central deste trabalho.

Entretanto, é verdade que nosso entendimento vai no sentido de afirmar que a importância do conceito se explicita também através de suas contradições e, por isso, precisaremos percorrer e comparar os quatro autores elencados de maneira atenciosa. A intenção não é, no entanto, a de elencar uma melhor ou pior teoria. Embora seja inevitável que certas predileções apareçam ao longo do trabalho estas não pretendem orientar um espectro de certo ou errado, mas apenas apresentar pontos de vista, formas de conceber a experiência subjetiva e, portanto, a experiência clínica. O objetivo central do trabalho é explorar o conceito da regressão ao longo da história da psicanálise entendendo que este permite acesso especial a um entendimento da clínica e da subjetividade na contemporaneidade.

Para dar conta do objetivo pretendido dividimos o presente trabalho de dissertação em quatro capítulos que, de alguma forma, se orientam por uma cronologia. No primeiro capítulo abordamos a teoria freudiana desde seus primórdios. Iniciamos a discussão apresentando a primeira concepção da ideia de regressão em psicanálise, que postula o conceito relacionando-o ao funcionamento onírico. Neste primeiro momento da teoria freudiana somos confrontados com a 
ideia de que existe no aparelho psíquico um movimento regressivo que atua na formação dos sonhos e também na formação dos sintomas neuróticos.

Em seguida, abordaremos ainda um segundo momento da teoria freudiana, no qual, a partir da formulação do segundo dualismo pulsional, temos a regressão associada à ideia de repetição e de retorno ao inanimado. Com o advento da noção de pulsão de morte passa a se considerar uma outra esfera da subjetividade na qual o retorno não estaria mais orientado apenas pelo prazer, passando a funcionar também além dele.

Essa novidade revoluciona a técnica. Antes norteada pelo objetivo de tornar consciente as representações inconscientes, entendendo ser esse o meio para dissolução do sintoma neurótico, ao se deparar com vivências não representadas, passa a se considerar também a importância das construções em análise. Acompanharemos as importâncias dessas mudanças clínicas abordando sobretudo as concepções da função do terapeuta no par analista-analisando.

Em um segundo capítulo seguiremos com as contribuições do psicanalista húngaro Sándor Ferenczi. Apesar de discípulo e amigo de Freud, veremos como o autor é responsável por inovações importantes, sobretudo no que diz respeito a clínica. Iniciaremos a discussão abordando a originalidade de seu trabalho de 1924, Thalassa. Nele Ferenczi apresenta a regressão, em seus aspectos filo e ontogenético, como força atraída pela onipotência da união com o meio. Ao longo de sua teoria sobre o desenvolvimento do sujeito e, sobretudo, do eu, trabalharemos com a ideia de um desejo de regressão ao útero materno.

Ainda no mesmo capítulo iremos introduzir as experimentações clínicas do húngaro que, ao atender "pacientes difíceis", inovou no que diz respeito a técnica. Embora algumas de suas explorações tenham tido como consequência uma recusa de seu nome dentre o meio psicanalítico, foram também elas que possibilitaram uma ampliação da clínica. A partir de seu olhar sensível nasce uma técnica que inclui o analista como sujeito ativo e percebe, em suas ações, efeitos diretos na subjetividade do paciente. Nesse sentido, apresentaremos sua concepção do trauma - compreendido pelo autor como fenômeno exógeno - e o nascimento da percepção da regressão enquanto vivência terapêutica. É sua atenção voltada para 
os primórdios do desenvolvimento e para a importância do ambiente que permite o surgimento de uma clínica pautada no manejo.

No terceiro capítulo abordaremos dois autores que, na esteira do trabalho de Ferenczi, deram destaque em sua obra à relação paciente-analista e incluíram, cada vez mais, a regressão enquanto fenômeno clínico e intersubjetivo. O primeiro deles é o húngaro Michael Balint, com o qual exploraremos dois tipos de regressão, a "maligna" e a "benigna". E o segundo é o britânico Donald Winnicott, que postula a ideia de "regressão à dependência". Ambos autores, entretanto, compartilham da compreensão de que a regressão em análise pode ser meio para criação de novas formas de existência, estas, mais orientadas pela saúde.

Veremos com Balint uma nova concepção do período da constituição subjetiva, que questiona a pertinência da ideia de narcisismo primário e opta por propor um experiência de "amor primário". Orientados por este conceito e o da "falha básica", trabalharemos as ferramentas oferecidas para descrever os estados regressivos. Apresentaremos também suas cuidadosas contribuições sobre a função do analista que, associado à função materna no período do "amor primário", deve viabilizar uma atmosfera harmoniosa.

Com Winnicott, exploraremos em especial sua teoria do desenvolvimento, que pensa a todo momento o indivíduo em relação com o meio. Completamente afastado de uma concepção pulsional, trabalharemos outra noção de saúde e outros tipos de defesa psíquica. A partir desse olhar diferenciado, exploraremos a regressão como possibilidade clínica essencial para lidar com certos tipos de pacientes, como exemplo, aqueles que ele chamou de "falso self". Para tanto, acompanharemos de maneira mais cuidadosa suas recomendações sobre o manejo do analista.

Por fim, no último capítulo do trabalho, iremos abordar a clínica contemporânea à luz de um recorte feito a partir dos pontos elencados como fundamentais nos capítulos anteriores: contratransferência, corpo e manejo. Após uma exploração do conceito de regressão nos quatro autores anteriores, entendemos esses pontos como essenciais para afirmar o lugar de tal experiência 
clínica na contemporaneidade. Para tanto, faremos uso sobretudo de autores mais atuais, dentre eles: Ogden, Bollas, Borges, Minerbo, Birman, Rozenthal, entre outros.

Em uma tentativa de dar corpo ao trabalho, nesse quarto capítulo contaremos também com vinhetas clínicas. Essas serão tanto retiradas de casos publicados quanto relatadas a partir de experiências pessoais. Acreditamos ser esta uma maneira sincera e fiel de manejar um conceito tão delicado e clínico. 


\section{2. \\ A regressão como movimento intrapsíquico em Freud}

No intuito de pontuar historicamente o nascimento da psicanálise, é comum a solução de atribuí-lo à obra "A Interpretação dos sonhos" (1900/2017), publicada por Freud na virada do século XIX para o XX. Nesse trabalho, o neurologista reúne as conclusões de seus estudos sobre a histeria (iniciados com Breuer e publicados em "Estudos sobre a histeria" (1895)) somando-os aos dos processos oníricos - como indicado pelo título - em uma tentativa de descrever o funcionamento psíquico neurótico. Logo, temos uma primeira esquematização do que virá a ser entendido como objeto central do estudo psicanalítico clássico: o inconsciente. $\mathrm{O}$ nascimento da psicanálise coincide, portanto, com o da primeira tópica, na qual o aparelho psíquico é separado em três instâncias que interagem de maneira dinâmica: a consciência, o pré-consciente e o inconsciente.

Nesse primeiro tempo da obra freudiana já se anuncia uma tendência que será continuada ao longo de sua teoria, esta é, a de uma compreensão econômica dos processos "anímicos". Seja falando dos sintomas, dos sonhos ou dos atos falhos - ou seja, sempre que tratando das manifestações do inconsciente -, Freud os justifica a partir da necessidade de descarga para que haja uma manutenção do equilíbrio energético. Embora esses processos citados ganhem destaque em sua teoria, o funcionamento psíquico como um todo é descrito a partir desse princípio que aponta para um incessante funcionamento em busca de prazer. O sujeito é constante receptáculo de estímulos externos que serão, ou não, retidos, manipulados e recalcados em função desse mesmo objetivo. É a partir dessa tentativa, de definir a relação entre as instâncias psíquicas descritas pela primeira tópica entre si com o mundo externo, que Freud desenvolve o esquema pente. Este nos interessa em particular por ser a primeira ocasião na qual o psicanalista aborda a questão da regressão.

É no capítulo 7 de "A Interpretação dos sonhos" (1900/2017) que Freud expõe, a partir do diagrama que veio a ser chamado de "esquema pente", o funcionamento onírico. Enquanto os processos psíquicos que ocorrem durante o período de vigília deslocam-se da via sensível para a via motora, ou seja, recebem 
estímulos e respondem aos mesmos através de ações, durante o sono o processo se dá de maneira inversa. Freud dirá que ocorre uma regressão tópica, formal e temporal. Portanto, desde os primórdios da teoria freudiana, a regressão é um processo intrapsíquico.

Em um primeiro momento o conceito serve para descrever o funcionamento do aparelho psíquico durante a produção onírica; já em um segundo momento ele fará uso da mesma lógica para expor o trabalho da formação do sintoma. No texto "Três ensaios da teoria da sexualidade" (1905b/2016), por exemplo, ele emprega o desenvolvimento sexual infantil para explicitar como os sintomas estarão sempre referidos a uma fixação pulsional ocorrida em uma das fases sexuais descritas.

Ainda neste capítulo veremos também o lugar ocupado pela ideia de regressão no segundo dualismo pulsional, no qual pulsões de vida são opostas às de morte. Estas tendo como aspecto importante uma força conservadora, ou seja, regressiva na medida em que aponta para um retorno ao inorgânico. Nesse segundo tempo da teoria nos deparamos, portanto, com uma regressão que se apresenta metapsicologicamente via uma força que busca retornar e, clinicamente, através do que Freud chamou de "compulsão à repetição".

Por fim, apresentaremos aspectos técnicos importantes com o intuito de mapear a função do analista para Freud. Veremos como em suas recomendações o analista ocupa um lugar pouco implicado enquanto sujeito, se atendo a uma função mais observadora. Essa delimitação nos será essencial na medida em que avançarmos com os autores considerados relacionais. Veremos como a ideia de transferência apresentada por Freud será expandida e a sua técnica ampliada.

O que pretendemos demonstrar com essa breve introdução é que, na teoria freudiana e, portanto, na psicanálise clássica, a noção de regressão se vê sempre associada a processos exclusivamente intrapsíquicos, ou seja, não toma o ambiente como decisivo para as produções subjetivas. Essa característica não é, entretanto, restrita a este conceito específico, é mais uma marca do pensamento freudiano e desse primórdio da psicanálise, que se ocupa sobretudo da neurose e do pulsional. 


\section{1}

\section{Regressão na primeira tópica: sintomas presentes e suas origens passadas}

Na abertura do livro “A Interpretação dos Sonhos” (1900/2017), Freud fala sobre o lugar que o estudo dos sonhos ocupou outrora. Objeto de profecias, bruxaria e estudos místicos, o neurologista afirma ser esta a primeira vez que o mundo onírico é abordado sob um olhar científico. Sua aproximação deste estudo não foi, entretanto, intencional, se deu como consequência de seu contato com as histéricas em uma tentativa de descrever e anular seus sintomas "conversivos"1. Ao estudar casos como o de Anna $\mathrm{O}^{2}$ (atendido por J. Breuer), Freud percebeu uma semelhança entre a linguagem dos sonhos e aquela dos estados dissociados das histéricas. Em ambas situações chamava a atenção um distanciamento da consciência marcado por um esquecimento e pela presença de elementos nonsense. Teria sido esta mesma percepção que levara P. Janet ${ }^{3}$ a pensar em uma "double conscience"4.

Nessa "segunda consciência" manifestavam-se vivências passadas que, na medida em que eram revisitadas, desarmavam o sintoma. Foi a partir desses relatos que Freud traçou uma equivalência entre a linguagem do sintoma e a dos sonhos, o que permitiu a ele enumerar alguns mecanismos comuns a estes dois modos de produção psíquica: 1) deslocamento; 2) condensação e; 3) figurabilidade. Essas características aparecem explicitadas no capítulo $6^{5}$ da

1 Freud (1894) define o fenômeno histérico da conversão como um sintoma resultante da separação de representações psíquicas. A representação afeto desaparece do psiquismo e a representação palavra é deslocada para o corpo. É, portanto, um sintoma marcado por um salto do psíquico para o somático; mas difere do que será mais tarde entendido como sintoma psicossomático. O sintoma psicossomático não conta com uma representação, pelo contrário, nunca pôde ser representado psiquicamente e por isso se manifestou no corpo.

2 Anna O. foi uma paciente atendida por Josef Breuer cujo caso foi escrito por Freud e primeiramente publicado no livro "Estudos sobre a histeria" (1896). Sua contribuição enquanto paciente é valorizada principalmente pela sua descrição do método psicanalítico como uma "talking cure" - termo por ela cunhado. Mais tarde ela foi identificada como Berta Pappelheim.

3 Pierre Janet (1859-1947). Foi um neurologista francês que trabalhou com Charcot no Salpêtrière utilizando a hipnose como tratamento da histeria. Suas contribuições são frequentemente debatidas na obra freudiana.

${ }^{4}$ Double conscience ou seconde conscience foram os termos utilizados por Janet para descrever o estado psíquico observado nas dissociações histéricas e nas hipnoses. Em condições normais essa instância psíquica atuaria de forma integrada, de forma que esta "segunda consciência" se torna evidente apenas através de fenômenos dissociativos.

5 O capítulo leva o título de "O Trabalho do sonho". 
"Interpretação dos sonhos" (1900/2017), no qual Freud aborda o processo de construção do enredo ${ }^{6}$ e outros elementos oníricos.

Já a grande novidade postulada na parte B do capítulo 77, e que a nós interessa em especial, é o caminho regressivo pelo qual o sonho se constrói. Ocorre que, durante o sono, a censura que durante o dia se vê ativa no préconsciente é rebaixada e os estímulos sensoriais vindos do externo diminuem. Essas alterações permitem que a força atrativa constantemente exercida pelo inconsciente se torne maior do que aquela que mantém a consciência como instância primordialmente ativa durante a vida desperta. $\mathrm{O}$ eu vigilante descansa $\mathrm{e}$ o sistema inconsciente produz. Nas palavras de Freud:

\begin{abstract}
A única maneira pela qual podemos descrever o que acontece nos sonhos alucinatórios é dizendo que a excitação se move em direção retrocedente. Em vez de se propagar para a extremidade motora do aparelho, ela se movimenta no sentido da extremidade sensorial e, por fim, atinge o sistema perceptivo. Se descrevermos como "progressiva" a direção tomada pelos processos psíquicos que brotam do inconsciente durante a vida de vigília, poderemos dizer que os sonhos têm um caráter "regressivo". (Freud, 1900/2017, p. 572)
\end{abstract}

Assim, embora o sonho em si seja experienciado já próximo à consciência já que o que percebemos dele é sua elaboração -, a matéria bruta desse conteúdo é material psíquico inconsciente (regressão tópica) e, portanto, necessariamente mais antigo (regressão temporal) e em formas de expressão mais primitivas (regressão formal) - as chamadas imagens sensoriales. É nesse sentido que podemos entender os sonhos como uma produção alucinatória. Assim como nas alucinações características da psicose, nos sonhos também os neuróticos se julgam na presença de experiências sensoriais para as quais não há reais estímulos físicos. Há um retorno à via sensorial sem haver, entretanto, a percepção de estímulos externos, mas sim internos, pulsantes no inconsciente.

O rebaixamento da censura não é, contudo, exclusivo do dormir. Pelo o contrário, a compreensão desse processo durante o sonhar torna-se relevante na medida em que projeta luz sobre o mecanismo de formação do sintoma neurótico.

\footnotetext{
6 Podemos considerar que o enredo em si é um dos elementos oníricos, uma vez que este representa o trabalho da "elaboração secundária".

7 O trecho leva o título de "A regressão".
} 
A origem do sintoma, tão obscura mesmo para aquele que o possui, pode se tornar consciente durante a hipnose e, mais tarde, durante a associação livre. É assistindo a esse processo vivido por suas pacientes histéricas que Freud "descobre", no sujeito, um conteúdo a ele mesmo incapaz de acesso voluntário.

Assim como nos sonhos, também no sintoma há uma origem inconsciente que precisa ser transformada para se apresentar à consciência. Através dos mecanismos já citados - de deslocamento, condensação e figurabilidade podemos matar nossas mães em nossos sonhos, colocando-a no corpo de outrem, e viver, em uma perna paralisada, a representação de um conteúdo rejeitado pelo nosso eu. É apenas com o rebaixamento da censura - durante o sono, a hipnose ou a associação livre - que materiais recalcados podem se apresentar para a consciência e, mesmo nessas condições, exigem disfarces. Disfarces estes que são também evidentes em outras produções do inconsciente, como os atos falhos, os chistes, os lapsos...

Pontalis fala sobre essa correspondência entre o sintoma e o sonho em seu livro "Força de Atração" (1991). Em sua escrita vemos como a diferença reside mais no uso que se fará disso do que no seu processo de formação: “A diferença reside apenas nisso: o sintoma não é interpretável, o sonho sim. É que há um acesso possível aos 'pensamentos do sonho', enquanto que para desvelar os 'pensamentos do sintoma' é preciso fazer nada menos que uma análise.” (Pontalis, 1991, p.31)

Essa descoberta do material inconsciente - queira, do "pensamento do sonho" e do "pensamento do sintoma" - é o que Freud (1919/2010) considerará a terceira ferida narcísica na humanidade: o eu não é mais senhor em sua própria morada. Nela contemos a descrição dos fenômenos oníricos, dos sintomas neuróticos e do método da psicanálise, que trabalhará no sentido de desbravar essa parte do eu que, embora inacessível por definição, não cessa de trabalhar. A interpretação dos sonhos é, portanto, interpretação de material inconsciente. E a técnica psicanalítica fundada por Freud pretende - balizada por princípios teóricos e técnicos que ainda iremos aqui definir - seguir os movimentos regressivos do 
aparelho psíquico até seus materiais originários a fim de solucionar o sintoma histérico. Novamente, recorremos a Pontalis (1991) para expressar tal ideia:

Analogia com o sonho: absurdo, imprecisão, incoerência do conteúdo manifesto, lógica do conteúdo latente. A finalidade é então substituir pela lembrança (poderíamos aqui preferir a velha palavra "remembrança") as "reminiscências" de que sofreria o histérico, isto é, de um regresso ao presente de imagens passadas, não identificadas como tais [...] (Pontalis, 1991, p.73)

A analogia proposta exalta o fato de haver, tanto no sintoma como no sonho, a presença de uma linguagem inconsciente como base. O conteúdo manifesto seria, em todo seu caos, o resultado do pensamento latente que precisou ser transformado para poder se manifestar. Essa transformação é o que torna o conteúdo incompreensível, porém, pensável. O caráter enigmático dos sonhos e dos sintomas evidencia as diferentes lógicas que regem a consciência e o inconsciente.

Há ainda outro ponto no qual devemos nos aprofundar no que diz respeito a origem da produção onírica e sintomática. Na medida em que Freud caminha em seus atendimentos com as histéricas, seja por via da hipnose ou da associação livre ou mesmo uma mistura entre as duas técnicas, ele percebe que o evento embrionário do sintoma é sempre de cunho sexual. Por trás das paralisias, cegueiras e afonias, há uma articulação entre o sintoma desenvolvido e uma cena traumática na qual o desejo sexual se viu contraposto a uma regulação. E quanto mais percorre esse caminho retrógrado em busca da causa do sintoma, mais Freud é levado a crer que não há nada em nossa subjetividade que possa ser explicado por uma casualidade. Uma mão paralisada é distinta de uma tosse histérica. Há, em cada sintoma, a denúncia de um ou mais eventos traumáticos. Como há, na numerosidade de mulheres histéricas, uma denúncia social. $\mathrm{Na}$ impossibilidade de manifestarem sua sexualidade, as mulheres paralisam membros. Reproduzem, no corpo, o enrijecimento que lhes é exigido pela ordem social.

Entretanto, não só as histéricas têm seus sintomas associados a conflitos sexuais. Freud dirá que todos os sintomas, assim como todos os sonhos, remontam a desejos sexuais infantis que tiveram de ser recalcados. Nesse sentido, a norma 
não cede privilégios. A vida sexual infantil e a limitada capacidade de rememoração da mesma é o que une os neuróticos. Nas palavras de Freud:

Na concepção popular do instinto sexual, ele está ausente na infância e desperta somente no período da vida que designamos como puberdade. Isso não é um erro qualquer, mas de grandes consequências, pois principalmente a ele devemos nosso atual desconhecimento das condições fundamentais da vida sexual. (Freud, 1905b/ 2016, p.73)

Se antes de Freud se entendia como sexualidade a experiência genital - o coito -, mais tarde na teoria isso passa a ser apenas o último destino de um longo desenvolvimento percorrido pela libido. Desenvolvimento este que era renunciado pelos estudos médicos devido a uma censura social, ou, para usar o termo psicanalítico, ao recalque. Para Freud, a amnésia infantil - o esquecimento dos primeiros anos de vida - "consiste num mero afastamento da consciência (repressão)" (Freud, 1905b/2016, p.76). Individualmente, evidenciamos o trabalho do recalque nesse apagão da vida sexual infantil e, socialmente, o endossamos na medida em que aceitamos como sexualidade apenas aquilo que se dá a partir da vida do púbere.

É em "Três ensaios da teoria da sexualidade" (Freud, 1905b/2016) que o autor problematiza o que se entende como sexualidade até então, e o faz a partir de, essencialmente, três categorias: 1) o que ele chama de aberrações, capítulo no qual descreve os desviantes da heteronormatividade sexual e as perversões; 2) a sexualidade infantil; 3) e a puberdade. Para o presente trabalho nos interessam em específico o segundo - já que, ao falar do desenvolvimento sexual infantil, Freud descreve um percurso da libido que servirá como base para sua teoria do sintoma neurótico - e o terceiro capítulo, no qual faremos uso do tópico acrescentado em 1914, "A Teoria da libido".

O trabalho de Freud de percorrer as vias paralelas entre a neurose e o desenvolvimento sexual abre espaço para pensar as diferenças entre o amadurecimento obsessivo e o histérico. Ao comparar a origem dos dois tipos de sintoma neurótico, ele atribui a diferença entre os dois funcionamentos ao ponto do desenvolvimento ao qual regridem. Notamos esse aspecto regressivo do sintoma quando ele diz, por exemplo, que "a sexualidade dos psiconeuróticos 
manteve a situação infantil ou foi conduzida de volta a ela" (Freud, 1905b/2016, p.77). Ou seja, há, em todo desenvolvimento, um momento de fixação da libido em função de um conflito entre o desejo e a realidade - conflito este que define a condição neurótica. Freud discorre mais sobre o assunto em seu texto "Formulações sobre os dois princípios do funcionamento psíquico" (1911b/2010), no qual introduz a ideia de uma dissensão entre um princípio de prazer e outro de realidade.

Freud abre o ensaio apontando para uma característica geral da neurose: um afastamento da realidade. Segundo ele, "Os neuróticos dão as costas à realidade por considerá-la - no todo ou em parte - insuportável”. (Freud, 1911b/2010, p. 109). Aqui, podemos entender o "insuportável” como aquilo que é inaceitável pelo eu. Essa instância psíquica, embora não devidamente teorizada por Freud até $1923^{8}$, ao fundar a segunda tópica, pode ser, por ora, apreendida como a parte do sujeito que é consciente sobre si. Seria, de alguma forma, o que o indivíduo concebe sobre si mesmo. Fala-se, portanto, em um aspecto da neurose que seria o afastar da consciência os desejos pelos quais não sustenta se responsabilizar. Esse mecanismo distingue-se do da psicose que, em vez de afastar, nega.

A pergunta que se coloca e que é de alguma forma fundante na psicanálise, é: como podemos desejar algo sem o saber? Como pode o sujeito do desejar ser e não ser, ao mesmo tempo, ativo nessa ação? A reposta para essas interrogações só se torna possível ao incluir a noção de inconsciente, uma vez que é este que permite uma nova compreensão do sujeito na qual não se sabe tudo sobre si. Quando falamos desta instância segundo a primeira tópica, tomando como referência os sonhos, explicamos como a ela atribuímos o registro das vivências mais antigas. Nela, residem os primeiros "traços mnêmicos". E na medida em que esses primeiros registros antecedem a linguagem verbal e, principalmente, a inserção do indivíduo na ordem social, parece natural que eles não se manifestem em forma de representação verbal, mas sim como as já descritas imagens sensoriais. Porém, ao que devemos nos ater sobre essas primeiras vivências é, o que elas visam, e ao que se opõem. Segundo Freud, sendo os processos

\footnotetext{
8 Refirimo-nos, aqui, ao texto freudiano "O Eu e o Id".
} 
inconscientes os mais antigos, logicamente houve um momento no qual o sujeito era constituído por apenas eles, de forma que podemos chamá-los de primários. E os processos primários, diz então Freud (1911b/2010), obedecem a uma tendência principal, esta é: o princípio prazer-desprazer.

Tais processos se empenham em ganhar prazer; daqueles atos que podem suscitar desprazer a atividade psíquica se retira (repressão). Nossos sonhos noturnos, nossa tendência, quando acordados, de fugir às impressões penosas, são resíduos da dominação desse princípio e provas de seu poder. (Freud, 1911b/2010, p.111)

É, entretanto, do conhecimento empírico de todos o fato de que não levamos a vida apenas segundo este princípio. Fosse assim, viveríamos todos atropelando uns aos outros com nossos desejos ainda mais explicitamente do que já fazemos. Acontece que, ainda no início da vida, nos deparamos com a realidade, isto é, com a decepção, a ausência de satisfação, a frustração. Não importa o quanto se busca, o prazer daquela primeira "chuchada" nunca será reencontrado. A fantasia de um mundo regido pelo e para o bebê vai logo sendo confrontada com uma realidade externa que a embarrera, obrigando-o a se inserir em um mundo que vai além de suas próprias experiências sensoriais. Com isso em mente, Freud introduz o princípio de realidade:

Em vez disso, o aparelho psíquico teve que se decidir a formar uma ideia das reais circunstâncias do mundo exterior e se empenhar em sua real transformação. Com isso foi introduzido um novo princípio de atividade psíquica; já não se imaginava o que era agradável, mas sim o que era real, ainda que fosse desagradável. (Freud, 1911b/2010, p.112).

Freud nos introduz, então, às diferenças, ao conflito e à transição - parcial do princípio de prazer para o princípio de realidade, projetando luz sobre a transformação subjetiva que se dá em função do encontro com o externo. Se em um momento mais primário da constituição psíquica há apenas um inconsciente desejante, na medida em que nos deparamos com vetos somos obrigados a criar limites para esses desejos. Essas barreiras serão, com o tempo, não só externas mas também internas, atuando através das forças da censura e do recalque. Deixamos de viver apenas segundo nossos desejos e, dessa nova realidade, nasce 
também um eu, uma consciência. Instância que passa a ser protegida dos indomáveis desejos que fundam a subjetividade.

Voltando para o texto "Três ensaios sobre a teoria da sexualidade" (Freud, 1905b/2016), podemos agora melhor apreender a ideia de fixação da libido em um momento do desenvolvimento sexual e o porquê de sua relação com o sintoma neurótico. O que parece é que, esse momento ao qual nos referíamos, de uma primeira maior submissão à realidade, acontece em tempos diferentes para cada indivíduo - fases diferentes de seu desenvolvimento sexual que serão determinantes para a qualidade do sintoma desenvolvido. É em função deste tempo da fixação que será escolhido o tipo de solução de compromisso possível e satisfatória. Possível para a censura que circunda a consciência, satisfatória para as pulsões inconscientes que exigem descarga.

Ao introduzir sua teoria da libido, Freud (1905b/2016) lança mão de um percurso cronológico que percorre as seguintes etapas: 1) fase oral; 2) fase analsádica; 3) fase fálica; 4) período de latência e; 5) fase genital. Para ele, todo indivíduo nasceria com "germens de impulsos sexuais" (Freud, 1905b/2016, p.78) que, primeiro se desenvolvem para, depois, sofrerem uma supressão até chegarem ao seu ápice e seu maior delineamento na vida sexual adulta. A supressão, representada pelo período de latência, se associa ao que já aqui chamamos de amnésia infantil. É neste período que vemos ascenderem afetos como o nojo e a vergonha, que apontam, sobretudo, para o início de uma apreensão da moral.

Existem, porém, fases bem definidas da sexualidade que antecedem esse contato mais explícito e definitivo com a moral e com a realidade e que nos serão essenciais para caminharmos no entendimento da via regressiva tomada pelo sintoma. Primeiro vale pontuar que essas fases, evidentemente, não são demarcadas à toa. O que elas salientam, é que é a partir de necessidades biológicas que o circuito do prazer se constitui. A partir da necessidade de autorregulação corporal essas zonas do corpo, uma vez que serviram como fonte de satisfação, são tornada erógenas. Freud dará a esse tipo de pulsão o nome de "apoio". Em suas palavras: "No começo, a satisfação da zona erógena estava provavelmente ligada à satisfação da necessidade de alimento. A atividade sexual 
se apoia primeiro numa das funções que servem à conservação da vida, e somente depois se torna independente dela." (Freud, 1905b/2016, p.85)

Isso nos importa na medida em que estamos construindo um raciocínio sobre, primeiro o desenvolvimento erótico e egóico do sujeito, para então nos aprofundarmos nos movimentos regressivos dos mesmos. Veremos logo mais em Ferenczi como essas duas vias do desenvolvimento podem ou não estar alinhadas teoricamente. De todo modo, ao falarmos dessas marcações de partes do corpo, mais uma vez já podemos traçar um ponto de encontro entre a sexualidade e o sintoma histérico. Freud dirá que essas zonas erógenas, inicialmente evidenciadas pelo prazer de atender a necessidades básicas, exibem as mesmas características que as zonas "histerógenas". Ou seja, fala-se do papel do corpo na manifestação sexual e na descarga pulsional, que é qualquer coisa, menos aleatória.

No capítulo 3 do texto "Três ensaios sobre a teoria da sexualidade" (1905b/ 2016), há um acréscimo realizado em 1914, ano de publicação de "Introdução ao narcisismo", no qual Freud discorre sobre a "teoria da libido". É nele que temos uma definição do conceito de libido que nos servirá para entender do que falamos quando alegamos que há, no sintoma, um regresso a um ponto de fixação da libido. A descrição do conceito é a seguinte:

Estabelecemos o conceito de libido $^{9}$ como uma força quantitativamente variável que poderia medir processos e transposições no âmbito da excitação sexual. Considerando a sua origem especial, diferenciamos essa libido da energia que deve subjazer aos processos psíquicos em geral, e assim the emprestamos também um caráter qualitativo. (Freud, 1905b/2016, p.135)

Ao que parece, podemos trabalhar com o conceito da seguinte maneira: ele difere de uma energia qualquer, por incluir um caráter necessariamente sexual, mas se manifesta, de uma ou outra maneira, em função de uma mudança de valência. Suas influências no aparelho psíquico se expressarão, portanto, através de concentrações dessa energia. Freud dirá ser através da "produção, aumento ou diminuição, distribuição e deslocamento" (Freud, 1905b/2016, p.135) que se torna possível explicar as manifestações psiconeuróticas. Acontece que os eventos aos quais a libido se agarra não cessam de exercer uma força magnética. Embora

\footnotetext{
${ }^{9}$ Grifo do original
} 
inconscientes, o fato de estarem carregados de investimento faz com que pulsem constantemente no aparelho psíquico À maneira do conteúdo dos sonhos, que vem à tona na ocasião do relaxamento da censura que durante o dia faz força contrária para retê-lo longe da consciência.

Mais uma vez retornamos à analogia fundante da teoria psicanalítica entre o sintoma neurótico e os processos oníricos. É nela que melhor compreendemos a ideia de que eventos carregados de energia precisam ser descarregados. Mas ora, que eventos seriam esses? Falamos dos eventos do desenvolvimento sexual infantil que, marcados pelo traumático nascimento do princípio de realidade, que inibe o desejo, são tornados foco de fixação de libido. Ao falarmos das manifestações sintomáticas tratamos, portanto, de movimentos regressivos do aparelho psíquico que, por mais avançado que esteja no processo de desenvolvimento sexual, leva o indivíduo a expressar formas anteriores desse desenvolvimento. O sintoma é, assim como os mecanismos de trabalho do sonho, uma solução de compromisso (neste caso, entre o evento gerador de fixação libidinal - que, ao sê-lo, não pode ser expresso na consciência - e a necessidade de descarga). Assim, a histérica expressa no corpo um conflito resistente do período edípico, e o obsessivo, em seus deslocamentos de representações psíquicas, exercita seu ideal de controle - herança do período anal-sádico. Estes são exemplos simplórios e talvez excessivamente didáticos para alcançarmos o que Freud percebeu da vida sexual infantil no sintoma neurótico. Usemos uma de suas passagens:

Vislumbramos assim a fórmula de que os neuróticos mantêm o estado infantil de sua sexualidade ou são remetidos de volta a ele, e desse modo o nosso interesse se voltará para a vida sexual das crianças, e acompanharemos o jogo de influências que governam a evolução da sexualidade infantil até o seu desenlace em perversões, neurose ou vida sexual normal. (Freud, 1905b/2016, p.72)

A ideia apresentada se apoia também no conceito de trauma, que nesse primeiro momento da obra freudiana explora a ideia de "trauma em dois tempos". Aqui, nasce a noção prevalente ao longo do estudo psicanalítico de que o trauma não está na vivência em si; um mesmo evento não é traumático para todos. Isso porque, para que algo ganhe essa conotação, exige-se um segundo tempo que o 
signifique enquanto tal. Recorremos à sexualidade infantil para explicar também este fenômeno. Acontece que, um abuso sexual, uma masturbação, uma vivência genital na infância, ainda não pode ser compreendida enquanto sexual uma vez que a fase do desenvolvimento sexual estaria aquém de tal significação. Dessa forma, é apenas na vida adulta, ao reviver uma situação semelhante que coloca luz sobre o caráter da primeira vivência, que o trauma, e também o sintoma, se constitui.

Assim, quando falamos que a fase à qual o enfermo regride em sua neurose coincide com o momento da substituição do domínio exclusivo do princípio do prazer sob as pulsões sexuais por uma "co-regência" do mesmo com o princípio de realidade, pressupomos que, agora na vida adulta, o sujeito mais uma vez se deparou com esse conflito entre desejo e realidade. Esse conflito pode ser pensado também como um desencontro entre o que o sujeito deseja e o que seu eu permite. Permite fazer e mesmo pensar - representar.

E a regressão será, como descrita na Conferência XXII (Freud, 1916/2016), um retorno da libido a pontos de interrupção no desenvolvimento do sujeito, ou seja, o retorno da libido - que, regida pelo princípio do prazer, visa sempre a satisfação - ao momento em que teve a satisfação impedida pelo encontro com a realidade. Esse retorno não fala da regressão apenas como força de aspecto retroativo, mas a conceitua como um dos mecanismos neuróticos de formação de sintoma. A busca por certa satisfação, ao ser deparada com a realidade, é recalcada e sujeita a um retorno posterior sob forma de sintoma. Voltando ao artigo técnico de 1911, temos uma explicação de Freud:

Se for correto que cada etapa desses dois cursos de desenvolvimento pode se tornar a sede da predisposição para uma neurose posterior, é natural supor que a decisão sobre a forma da doença posterior (a escolha da neurose) dependerá da fase do desenvolvimento do Eu e da libido em que ocorreu a inibição do desenvolvimento que predispõe à enfermidade. (Freud, 1911b/2010, p. 118.)

Assim, para que possamos unificar as ideias apresentadas neste item, tratando-se da primeira tópica cabe entender o processo de regressão em Freud da seguinte maneira: é um processo intrapsíquico que aparece sobretudo na produção onírica e sintomática e que, portanto, serve de base para esse primeiro momento 
da técnica psicanalítica. Na medida em que contextualizamos a origem dos sintomas em momentos mais primitivos do desenvolvimento, a regressão se torna, ao mesmo tempo, problema e solução. Problema por ser sua ocorrência no aparelho psíquico a forma mesma de estruturação do sintoma, e solução por ser através dos métodos que baixam a censura e permitem o retorno e descarga destes pontos de fixação da libido que o neurótico retoma seu caminho "normal" do desenvolvimento. No nascimento da psicanálise Freud entende ser apenas acompanhando essa via regressiva de volta à origem do sintoma que o neurótico pode encontrar a cura.

\section{2}

\section{Regressão na segunda tópica: um retorno ao inanimado}

No intuito de explorar amplamente o conceito de regressão em Freud, devemos agora ingressar na segunda fase do seu pensamento mas, para tanto, precisaremos antes compreender por que ela se tornou necessária. Como vimos, desde 1900 a psicanálise tomou como modelo básico do aparelho psíquico aquele que o separa em três diferentes topos: o Ics, o Pcs e a Cs; e entendeu como conflito fundante a oposição entre as pulsões sexuais e as pulsões de autoconservação - ou do eu. Ou seja, o funcionamento psíquico era substancialmente descrito como um constante embate entre os desejos sexuais e a necessidade de preservação - fosse ela da vida do organismo ou da integridade e coerência do eu diante das normas sociais. Entretanto, essa explicação só se sustenta até 1914.

No texto "Introdução ao Narcisismo" (1914a/2010) Freud traz à tona uma questão que não mais pode ser desconsiderada. A partir da observação de fenômenos como o apaixonamento, o adoecimento e a manifestação de sintomas de megalomania ou paranóia - nos quais se observa "uma oposição entre libido do Eu e libido de objeto" (Freud, 1914a/2010. p.17) -, Freud percebe que também o eu é objeto de investimento libidinal. Ou seja, as pulsões sexuais que eram até então compreendidas como forças opostas à segurança do eu, também podem 
tomá-lo como objeto erótico. $\mathrm{O}$ eu deixa de ser apenas representante do sujeito que investe e passa a ser concebido também como objeto que recebe investimento. O problema dessa nova colocação é que, na medida em que afirmamos um investimento auto-erótico do eu, a dualidade pulsional se encontra sob o risco de se tornar um monismo. Um monismo pulsional era uma ideia defendida por Jung mas repudiada por Freud. Sobre o rompimento com esse primeiro dualismo pulsional Freud diz:

Precisamente porque em geral me esforço para manter longe da psicologia tudo o que dela é diferente, inclusive o pensamento biológico, quero neste ponto admitir expressamente que a hipótese de instintos sexuais e do Eu separados, ou seja, a teoria da libido, repousa minimamente sobre base psicológica, escorando-se essencialmente na biologia. Então serei consistente o bastante para descartar essa hipótese, se a partir do trabalho psicanalítico mesmo avultar outra suposição, mais aproveitável, acerca dos instintos. (Freud, 1914a/2010, p.21)

Essa "suposição mais aproveitável” lhe ocorrerá no período que segue o fim da Primeira Guerra Mundial ${ }^{10}$. Foi principalmente a partir da observação dos processos oníricos dos soldados que voltavam para casa que Freud pôde perceber o que até então aparecera apenas dentro de certas manifestações clínicas: a compulsão à repetição. Ainda neste capítulo abordaremos esse aspecto da clínica descrito primeiramente por Freud no texto de 1914 "Recordar, repetir e elaborar", mas por ora foquemos nas implicações dessa descoberta para uma compreensão metapsicológica.

Durante as primeiras décadas do estudo psicanalítico Freud tinha como pilar a noção de que o objetivo final de toda operação psíquica seria a obtenção de prazer. Prazer aqui entendido como uma descarga energética que gerava satisfação na medida em que aliviava a tensão do aparelho. Já o excesso de tensão, ou seja, a insuficiência de descarga, geraria desprazer. Nas palavras de Freud:

Decidimos relacionar prazer e desprazer com a quantidade de excitação - não ligada de nenhuma maneira - existente na vida psíquica, de tal modo que o desprazer corresponde a um aumento, e o prazer a uma diminuição dessa quantidade. (Freud, 1920/2010, p.163).

10 Ocorrida entre 1914-1918. 
Sua metapsicologia baseava-se, portanto, em um funcionamento econômico do aparelho psíquico que aplicava sobre as relações topológicas e dinâmicas um olhar essencialmente quantitativo.

Mas vejamos, na primeira parte do ensaio "Além do princípio do prazer” (1920/2010) Freud já anuncia que, apesar do princípio do prazer, ou seja, da constante tendência ao prazer em nossas ações psíquicas, é notável que nem sempre alcançamos um estado de satisfação. Há de haver, portanto, elementos que interpelam o caminho até o prazer. O primeiro impedimento citado por Freud é o princípio de realidade do qual já falamos. Garcia-Roza (1994/2009) o descreve da seguinte forma: Além do princípio de prazer... há o princípio de realidade, aprendemos nós. O
princípio de realidade era, até então, concebido como um princípio de regulação
psíquica que impunha à procura de satisfação desvios, paradas, substituições e
sobretudo renúncias. Ao caminho mais curto do princípio de prazer, o princípio de
realidade oferecia o caminho mais longo - mas de alguma forma também
gratificante - da renúncia. (Garcia-Roza, 1994/2009, p.132)

Mas fosse essa a única exceção da perpetuação do princípio do prazer ficaríamos com o primeiro dualismo, que tem como principal tendência a busca por prazer - a realização de um desejo - e, em sua contrapartida, um constante rodeio que preza pela necessidade de conservação do eu e do organismo. Veremos agora o porquê desse raciocínio, além de não tratar de uma dualidade - como vimos pelas conclusões apresentadas no texto "Introdução ao narcisismo" (1914a/ 2010) -, não pode dar conta de toda experiência subjetiva.

Esse primado do princípio de prazer, por assim dizer, torna-se objeto de questionamento na medida em que Freud se depara com quatro situações nas quais ele parece ser posposto. Elas são: 1) a manifestação da repetição na transferência clínica; 2) os sonhos de repetição na neurose traumática; 3) a brincadeira infantil do fort-dall e; 4) o "eterno retorno" (Freud, 1920/2010, p.182) de certos destinos na neurose. Ora, se visamos sempre prazer em nossas ações, por que repetimos situações de desprazer?

\footnotetext{
11 Brincadeira percebida por Freud na qual a criança afastava o brinquedo de si proferindo a interjeição "fort" (que significa "foi embora"), e depois a trazia para perto novamente dizendo " $d a$ " (que significa "aqui está"). Freud compreendeu que a brincadeira era, portanto, um jogo de desaparecimento e reaparição.
} 
A partir da observação desses fenômenos que não incluem nem satisfação e nem a proteção do eu, Freud determina que deve haver na compulsão à repetição percebida nesses casos uma forma de superação do princípio do prazer. Ou seja, existem operações do aparelho psíquico que atuam impelidas pela compulsão à repetição e não respondem à tendência da busca pelo prazer, até então soberana. "O que ainda nos resta é bastante para justificar a hipótese da compulsão à repetição, e esta quer nos parecer mais primordial, mais elementar, mais instintual do que o princípio do prazer, por ela posto de lado." (Freud, 1920/2010, p.184).

Mesmo a teoria do sonho, que defende haver por trás de todo ato de sonhar a tentativa de realizar um desejo sexual infantil recalcado, deve ser problematizada. Mas devemos nos atentar ao fato de que o problema colocado não é referente à existência de sonhos de angústia nem tampouco de ações que geram desprazer; ambas situações já foram explicadas pela diferenciação de topos e instâncias do psiquismo - um conteúdo pode ser prazeroso para um sistema e desprazeroso para outro. O caráter enigmático dos sonhos dos neuróticos traumáticos não se deve à qualidade do enredo do sonho mas sim a sua repetição. Freud diz: "Mas o fato novo e digno de nota, é que a compulsão à repetição também traz de volta experiências do passado que não possibilitam prazer, que também naquele tempo não podem ter sido satisfações" (Freud, 1920/2010, p. 179).

A questão parece simples: para que haja um desejo a ser realizado através de uma satisfação alucinatória, deve haver antes representações. O que Freud percebe é que nos sonhos traumáticos o objetivo não pode ser o de concretizar desejos, mas antes lidar com o estímulo que, quando vivido, não pôde sequer ser ligado e representado no aparelho psíquico. A repetição destes sonhos seria então, uma tentativa de "lidar retrospectivamente com o estímulo, mediante o desenvolvimento da angústia, cuja omissão tornara-se causa da neurose traumática." (Freud, 1920/2010, p.195).

A partir desta constatação nos deparamos com aspectos distintos da vida pulsional: em uma esfera (Pcs e Cs) se atua via ligações, pela produção de sintomas, formações reativas, etc. E, em outra (Ics), a energia é preservada de 
forma independente e desintegrada, tendo como conflito não o prazer-desprazer mas antes a possibilidade de ligação. Fala-se, portanto, em um processo que seria anterior, "além", daquele que se tomava como primordial no aparelho psíquico. Existe na vida psíquica um conflito que não diz respeito à forma de escoamento, às possibilidades de associação de representações, mas antes ao ímpeto de realizar ligações ou permanecer de forma desintegrada até aniquilar-se por inteiro. Recorremos a Freud para introduzir essa nova característica do sujeito a qual chamaremos de conservadora:

Um instinto seria um impulso presente em todo organismo vivo, tendente à restauração de um estado anterior, que esse ser vivo teve de abandonar por influência de perturbadoras forças externas, uma espécie de elasticidade orgânica ou, se quiserem, a expressão da inércia da vida orgânica.

Tal concepção do instinto soa estranha, pois já nos habituamos nele o fator que impele à mudança e ao desenvolvimento, e devemos agora reconhecer ali a expressão da natureza conservadora do vivente. (Freud, 1920/2010, p.202).12

É a partir dessa descoberta, de uma indubitável força conservadora e regressiva, que temos o pronunciamento de um novo conflito basal do funcionamento psíquico neurótico: a oposição entre as pulsões de vida e as pulsões de morte. As pulsões de vida representariam a unificação das antigas pulsões sexuais e pulsões do eu enquanto as de morte falariam desse novo aspecto do psiquismo representado pela repetição e pela "indiferença ao desprazer".

No decorrer do texto Freud cita algumas características sobre as pulsões de morte que devemos aqui explorar. Comecemos pela compreensão do seu aspecto "além". Essa palavra se presta aqui a uma dupla função; representa ao mesmo tempo o fato de serem mais primitivas e independentes. Ou seja, falamos necessariamente em forças que atuam em uma frequência diferente da do prazer, uma vez que para se concretizarem não precisam responder à conhecida dinâmica do aparelho psíquico, que tende sempre a uma constância energética. Falamos antes em uma ausência completa de energia. Se tomamos como meta das pulsões de vida as ligações e descargas que viabilizam a manutenção do equilíbrio energético, podemos descrever a meta das pulsões de morte como um esvaziamento total do aparelho psíquico, ora, a aniquilação do mesmo. Vai ser a

${ }^{12}$ Grifos do original 
partir do estudo de diversas outras formas de vida - e de morte e copulação - que Freud chega a formular que "o objetivo de toda vida é a mortel3" (Freud, 1920/2010, p.204). A questão não será, portanto, o destino da morte - como vimos na compulsão à repetição, o neurótico repete eternamente seu destino -, mas sim o trajeto até ela.

Quando falamos em pulsão de vida e morte, de maneira nenhuma estamos igualando-as aos desejos de viver e morrer respectivamente. Falamos antes em um direcionamento desta pulsão, uma forma de perpetuar-se. Temos na pulsão de morte a descoberta de uma intenção inerente ao sujeito de retornar ao seu estado primevo, o inorgânico. E nas pulsões de vida não uma negação da morte mas, nas palavras de Garcia-Roza (1994/2009), o objetivo de "evitar que a morte ocorra de uma forma não natural. Ela é a reguladora do caminho para a morte.” (GarciaRoza, 1994/2009, p.137). Assim, não temos no segundo dualismo pulsional uma oposição entre vida e morte, mas entre a forma de viver e morrer. As pulsões de vida, ao mesmo tempo que conservadoras na medida em que estão sempre buscando o reestabelecimento de um estado ideal do organismo ou uma primeira satisfação já inatingível, não podem deixar de fora seu caráter sexual que pretende perpetuar sua vida pela junção com outra.

O que Freud (1920/2010) conclui - ainda que de forma especulativa - a partir da exploração de outras formas de vida bem como dos movimentos repetitivos percebidos nos neuróticos traumáticos, é que a dualidade constituinte do sujeito responde à oposição entre progresso e regresso, entre ligação e desligamento, continuidade e descontinuidade. Sobre essa aparente tendência ao regresso Freud diz: "Deve ser antes um estado antigo, um estado de partida que a matéria viva certa vez deixou e ao qual aspira retornar, passando por todos os desvios do desenvolvimento." (Freud, 1920/2010, p.203).

E não é verdade que foi apenas com grande esforço que viemos à vida e que nos mantemos nela? O caminho fácil e desejado seria retornar a este estado inanimado que antecedeu a vida, a essa satisfação plena do não desejar - na qual reinaria o princípio de nirvana ou inércia. Mas a esse desejo se opõe outro, aquele

${ }^{13}$ Grifo do original 
que Freud apresenta da seguinte maneira: "Tais rodeios rumo à morte, fielmente seguidos pelos instintos conservadores, nos ofereceriam hoje o quadro dos fenômenos da vida." (Freud, 1920/2010, p.205). A partir do encontro com as influências externas, a tentativa do organismo de preservar-se inerte, de repetir infinitamente o mesmo curso de vida, se vê sem saída senão percorrer o desenvolvimento até poder, então, retornar ao estado que teria desde início conservado de forma natural.

Tomemos então as palavras de Freud para descrever enfim, e sucintamente, o segundo dualismo pulsional. Sobre as pulsões de vida ele diz: "a libido dos nossos impulsos sexuais coincidiria com o Eros dos poetas e filósofos, que mantém coeso tudo que é vivo." (Freud, 1920/2010, p.221). E sobre as pulsão de morte: são aquelas que funcionando além do princípio do prazer expressam através da compulsão à repetição, da agressividade e da ambivalência uma "necessidade de restabelecer um estado anterior" (Freud, 1920/2010, p.217).

É também baseado neste novo dualismo pulsional que nasce uma nova concepção do traumático. Como vimos no item anterior, nos primeiros anos da psicanálise Freud concebia o traumático como um evento sexual impassível de compreensão em um primeiro momento mas significado enquanto tal em um segundo. Ou seja, um trauma em dois tempos que se dava em função de um evento externo. Primeiro um evento real, dando um caráter mais exógeno ao trauma, e mais tarde um evento fantasioso, atribuindo ao trauma, como seria na teoria de Freud, um aspecto mais endógeno.

Aqui, no nascer do segundo dualismo, esse caráter endógeno do trauma será enfatizado. Na medida em que fala sobre as experiências vividas pelos neuróticos de guerra, marcadas pelo efeito do susto e do terror, descreve uma capacidade psíquica que seria a de se proteger de eventos extremos a partir de uma barreira psíquica. Freud diz que a neurose traumática seria "a consequência de uma vasta ruptura da proteção contra estímulos.” (Freud, 1920/2010, p.192). Essa ideia será desenvolvida também a partir da diferença que fará no texto "Inibição, sintoma e angústia" (Freud, 1926/2014) entre angústia automática e angústia sinal. Não vale nos estendermos nesta questão mas basta dizer que um nível de angústia serviria 
de proteção para eventos que necessitam de uma grande energia para ligar as excitações deles derivadas. Ou seja, a angústia teria uma função fortalecedora dessa barreira protetora. Nesse sentido, a imprevisibilidade das vivências dos neuróticos traumáticos, o caráter da surpresa, é o que reforça o aspecto traumático nessas experiências.

Entretanto, o desenvolvimento de Freud vai no sentido de afirmar que, apesar dessa membrana protetora para eventos externos, pode faltar para o sujeito uma proteção eficiente para forças vindas do seu próprio aparelho psíquico. Força esta que não seria outra coisa senão a pulsão. Ou seja, também a pulsão pode ser traumática, podendo ela mesma constituir um quadro que se assemelha daqueles diagnosticados como neuroses traumáticas. Nas palavras de Freud:

A falta de uma barreira contra excitações que venham do interior, na camada cortical receptora de estímulos, terá a consequência de que tais transmissões de estímulos adquirem a maior importância econômica e frequentemente dão ensejo a distúrbios econômicos equiparáveis às neuroses traumáticas. (Freud, 1926/2014, p. 198)

Mais do que nunca, somos obrigados a associar o traumático em Freud a uma disfunção intrapsíquica mais do que a uma reação a um acontecimento externo (ao ambiente), como veremos nos próximos autores. Ao atribuir às próprias pulsões um caráter traumático na medida em que define uma parcela delas como disjuntivas, Freud afirma, mais uma vez, seu olhar mais econômico do que relacional para as condições psíquicas.

Se fosse de nosso interesse, o tema poderia ser ainda mais prolongado, perseguindo os estudos de Freud sobre a agressividade e a destrutividade como expressão da pulsão de morte tanto na esfera individual quanto social ${ }^{14}$ na última fase de sua produção. Porém, devemos ater-nos ao que interessa. Acompanhando o desenvolvimento e as conclusões de Freud sobre as pulsões de morte, devemos enfatizar, sobretudo, seu caráter regressivo. Se no primeiro período da teoria psicanalítica de Freud compreendíamos como movimento regressivo aquele

\footnotetext{
${ }^{14}$ Sobre a atuação da destrutividade do indivíduo em uma esfera mais social referimos o autor aos textos "Mal-estar na civilização" (1930/2010), "Considerações atuais sobre a guerra e a morte" (1915b/2010), “O futuro de uma ilusão" (1927/2010), "Por que a guerra?" (1933/2010), entre outros textos e conferências.
} 
tomado pela produção do sonho e do sintoma, no segundo período a ideia de regressão ganha ainda mais destaque, operando como uma das duas principais forças atuantes no aparelho psíquico. Ao colocar como dualismo fundamental a oposição entre as pulsões de vida e as pulsões de morte, Freud declara que aquilo que persegue o sujeito é, por um lado o impulso por ligação e continuidade e, por outro, um constante ímpeto pelo desligamento, pelo retorno à ausência de excitação. Ou seja, de um lado o progresso, do outro, o regresso.

\section{3}

\section{Técnica psicanalítica clássica: uma transferência unilateral}

Após esse percurso mais teórico, devemos concentrar nossos esforços para compreender como esse fenômeno da regressão se manifesta, ou não, no enquadre clínico. Essa discussão se tornará especialmente importante no decorrer deste trabalho, ao explorarmos outros autores. Isso porque, diferentemente de Freud, todos os outros teóricos abordados nesta pesquisa são considerados autores relacionais, ou seja, pensam a situação clínica a partir do encontro intersubjetivo entre paciente e analista. Nesse aspecto, temos Freud em um lugar de exclusividade neste trabalho, sendo ele o único representante de um olhar psicanalítico predominantemente intrapsíquico, econômico e pulsional.

Neste ponto acredito termos que adiantar aspectos do pensamento relacional para melhor compreendermos a importância de se abordar comparativamente a técnica freudiana e em especial sua concepção da posição do analista e do paciente. No próximo capítulo exploraremos o trabalho de Ferenczi a fim de compreender como a obra deste contemporâneo de Freud pôde, ao mesmo tempo, mantê-lo na posição de fiel discípulo da psicanálise, e dá-lo o apelido de "enfant terrible”. Ferenczi soube manter em um mesmo texto a noção de pulsão de morte, e trazer a novidade da importância do acolhimento no desenvolvimento da criança15. A nós importa mais a novidade, já que é nela que reside o nascimento de um novo olhar psicanalítico. Mas por ora basta reter a seguinte informação: não só

15 O texto referido é o “A criança mal-acolhida e sua pulsão de morte” (Ferenczi, 1929/2011) 
o pulsional mas também o entorno pode ser traumático. Adentremos os textos técnicos de Freud já com este futuro cotejo em mente.

Se tomamos a psicanálise como apresentada por Freud, como uma ciência mas também como um método terapêutico, cabe aqui explorar os princípios técnicos por ele apontados a fim de compreender como o que vimos da teoria foi aplicado na técnica. Para tal tarefa, faremos uso de seus artigos técnicos ${ }^{16}$. Neles temos as principais regras claramente enumeradas, o que permite uma organização sistemática de seu método.

Frequentemente Freud abre seus textos com uma espécie de revisitação da trajetória psicanalítica. É o caso em “Além do princípio do prazer” (1920/2010), em "Recordar, repetir e elaborar" (1914b/2010) e em alguns outros textos bem como conferências. Nessas revisões ele costuma enfatizar e demarcar os seguintes momentos da técnica: um primeiro baseado no método catártico e na técnica hipnótica, um segundo no qual surge a regra fundamental da associação livre como via de acesso às memórias recalcadas e, por fim, um trabalho que leva em conta as resistências à análise tendo como meta suas dissoluções. Mas, segundo ele, mesmo com todas as mudanças e explorações, há um objetivo que permanece absoluto: “O objetivo dessas técnicas permaneceu inalterado, sem dúvida. Em termos descritivos: preenchimento de lacunas da recordação; em termos dinâmicos: superação das resistências da repressão." (Freud, 1914b/2010, p.195). Ora, busca-se, sobretudo, uma espécie de libertação do material recalcado.

Ainda que a técnica tenha sofrido algumas revisitações ao longo da obra freudiana, parece incontestável em seus escritos que, se tivéssemos que elencar um aspecto como medular, este seria o que Freud nomeou como "regra fundamental": a "livre associação". E a ela adicionaríamos ainda a paridade da "escuta flutuante". Ambas dizem respeito ao estado no qual a dupla pacienteanalista deve se encontrar no momento da análise: de entrega ao inconsciente. $\mathrm{O}$ que isto quer dizer? Segundo Freud - a partir de suas descobertas através da

\footnotetext{
16 Artigos escritos por Freud com o intuito de delimitar a prática psicanalítica que se difundia com velocidade perigosa. Em suas palavras: “(...) expor claramente ao aprendiz o que já é conhecido e poupar tempo e esforço ao iniciante na prática psicanalítica, oferecendo-lhe instruções adequadas (...)" (Freud, 1911c/2010, p.123). Dentre eles temos "Formulações sobre os dois princípios do funcionamento psíquico" (1911b/2010), "Dinâmica da transferência" (1912a/2010), "Recordar, repetir e elaborar" (1914b/2010), "Construções em análise" (1937b/2018), entre outros.
} 
hipnose -, o paciente seria capaz de rebaixar suas censuras mesmo em um estado de vigília caso se deixasse falar livremente, sem seguir nenhuma lógica específica ou ceder a nenhuma censura. $\mathrm{O}$ analista deve convocar o paciente a este lugar. Fale mesmo aquilo que não parece importante, aquilo que há de irrelevante, de vergonhoso, de imoral - ele diria. Freud nos presenteia com uma imagem do que seria este estado psíquico do analisando no texto "O início do tratamento" (Freud, 1913/2010). Ele diz: “comporte-se, por exemplo, como um viajante que está sentado à janela do trem e descreve para seu vizinho, alojado no interior, como se transforma a vista ante seus olhos" (Freud, 1913/2010, p.181). Evidente que neste cenário o paciente corresponde ao "viajante" e o analista ao "vizinho".

O analista não é, entretanto, um "vizinho" qualquer. Ele complementaria esse estado proposto ao paciente fazendo o mesmo com sua escuta; permitindo a sua atenção um relaxamento de forma que o conteúdo a sobressair em sua escuta se dê, não por um processo racional, mas inconsciente. Freud formula esse estado da seguinte maneira: "manter toda influência consciente longe de sua capacidade de observação e entregar-se totalmente a sua 'memória inconsciente', ou, expresso de maneira técnica: escutar e não se preocupar em notar alguma coisa." (Freud, 1912a/2010, p.150). Assim, de seu estado de rebaixamento, o analista poderia "melhor escutar" o conteúdo vindo do paciente que livre associa. A experiência em jogo seria sempre, porém, a do paciente. Ao analista caberia se ater a uma função de receptáculo. Do texto "Recomendações ao médico que pratica psicanálise" (Freud, 1912b/2010) podemos extrair duas passagens nas quais esse ideal é explicitado: "Expresso numa fórmula: ele deve voltar seu inconsciente, como órgão receptor, para o inconsciente emissor do doente, colocar-se ante o analisando como o receptor do telefone em relação ao microfone." (Freud, 1912b/ 2010, p.156); e "O médico deve ser opaco para o analisando, e, tal como um espelho, não mostrar senão o que lhe é mostrado." (Freud, 1912b/2010, p.159).

Esse par associação livre e escuta flutuante é suficiente para descrever um primeiro momento da técnica, mas logo temos que somar a ele a noção de resistência e transferência. Para inaugurar esses conceitos podemos recorrer ao 
Caso Dora ${ }^{17}$, o primeiro dos cinco grandes $\operatorname{casos}^{18}$ de Freud. O caso publicado em 1905 relata, apoiando-se principalmente na interpretação de dois sonhos, um quadro de histeria. Tendo esse caso sido atendido após aqueles descritos nos "Estudos sobre histeria" (Freud; Breuer, 1895/2010), a hipnose não mais era uma ferramenta utilizada. Em seu lugar já entrava em vigor a regra fundamental, herança do atendimento de Anna O. (paciente que teria primeiramente falado sobre o potencial de uma talking cure). Embora em termos teóricos Freud descrevesse um analista silencioso, que deixasse a paciente falar livremente, em seu texto sobre Dora vemos como - talvez em função de um enorme esforço para afirmar certos aspectos do aparelho psíquico e da arte de interpretação dos sonhos - ele por vezes adotava um lugar de notória atividade. Mas foi devido a esse processo de intervenções e afirmativas por parte de Freud, e rejeições e questionamentos por parte de Dora, que o pai da psicanálise pôde notar o elemento da transferência na relação analítica.

Como se sabe, o caso de Dora não foi considerado um bem sucedido Freud inclusive expressa em seu texto enorme frustração ao saber que a paciente iria deixá-lo. Mas foi devido a esse insucesso que ele teve a oportunidade de repensar o caso a ponto de entender que, a força que deixara de ver por estar excessivamente preocupado com a interpretação de cada elemento e com a busca pela sexualidade recalcada, era a transferência. No posfácio do caso ele afirma:

De modo que fui surpreendido pela transferência, e, em virtude desse algo desconhecido em que eu lhe lembrava o sr. K., ela se vingou de mim como quis se vingar dele e me abandonou, tal como acreditou haver sido enganada e abandonada por ele. Assim ela atuou $^{19}$ uma parte essencial de suas lembranças e fantasias, em vez de reproduzi-la no tratamento. (Freud, 1905a/2016, p.316)

Ou seja, a descontinuidade do tratamento talvez pudesse ser evitada caso ele tivesse percebido o lugar que ocupara naquela relação. O analista nunca é só o analista e ali "caíra" também nas imagens do pai e do Sr. K. A esses aspectos da transferência - não reconhecidos e, portanto, tampouco apontados - fora atribuída a causa para a resistência de Dora ao tratamento.

${ }^{17}$ Caso publicado em 1905 com o título de "Análise fragmentária de um caso de histeria".

${ }^{18}$ Eles são, "O caso Dora" (1905), "O Pequeno Hans" (1909), "Homem dos Ratos" (1909), "Homem dos Lobos" (1918) e "Schreber" (1911a).

${ }^{19}$ Grifo do original 
É a partir desse caso que Freud se ocupa a pensar este elemento da relação paciente-analista, o qual ele irá conceituar propriamente no texto "A dinâmica da transferência” (Freud, 1912a/2010). Se antes a base da psicanálise, de deixar o paciente falar e saber escutar, era suficiente, devem agora ser acrescentados alguns questionamentos: A quem o paciente fala? Que relações repete? O que deixa de falar? Por que interrompe suas falas quando o faz? Veremos como esses aspectos clínicos serão fundamentais para o desenrolar do método psicanalítico.

Em "A dinâmica da transferência" (Freud, 1912a/2010) temos enfim uma definição mais oficial do termo que já vinha sendo usado desde o início da obra freudiana. $\mathrm{O}$ autor falará da transferência como padrões de formas de se relacionar que se repetem ao longo da vida e que se tornarão evidentes também na relação com o analista. Para usar suas próprias palavras: "num clichê (ou vários), que no curso da vida é regularmente repetido, novamente impresso" (Freud, 1912a/2010, p.135). No decorrer do texto destrinchará o conceito segundo alguns aspectos, como suas facetas consciente e inconsciente e suas manifestações de forma positiva ou negativa, mas a nós importa especialmente o manejo que se fará desse fenômeno clínico.

Se falamos da transferência como padrões relacionais que não podem ser eximidos de nenhuma relação, é claro que também na relação com o "médico" ela se apresentará. Freud diz que o "doente" "incluirá o médico numa das “séries"” (Freud, 1912a/2010, p.136), ou seja, o associará a algum destes padrões já existentes em sua vida subjetiva. Na verdade é ali, na relação paciente-analista, que ganhará destaque ao tornar-se ferramenta importante para o tratamento. É isso que Freud responde ao questionamento hipotético de se, e por que, a transferência se daria apenas na psicanálise. Na relação psicanalítica ela é notada como necessária mas também como maior resistência, de forma que não pode passar despercebida. A proposta de Freud vai no sentido de explicitar esse processo, mais uma vez, pelo viés econômico do aparelho. Assim como os sonhos e as outras manifestações do inconsciente, a transferência pode ser entendida como uma solução de compromisso entre as diferentes instâncias psíquicas, como uma "distorção" que satisfaz a resistência. 
A lógica apresentada propõe que a transferência é uma manifestação substituta à tão buscada recordação. Em vez de rememorar a situação "esquecida" e preencher as lacunas de memória que necessariamente se associam às origens dos sintomas, o paciente atua essas experiências passadas na relação com o analista. Disso extraímos esse seu caráter duplo: resistência por impedir a recordação, mas necessária por fazer vínculo e dar acesso a um material precioso para a análise. Freud coloca da seguinte maneira:

Os impulsos inconscientes não querem ser lembrados como a terapia o deseja, procurando, isto sim, reproduzir-se, de acordo com a atemporalidade e a capacidade de alucinação do inconsciente. Tal como nos sonhos, o doente atribui realidade e atualidade aos produtos do despertar de seus impulsos inconscientes; ele quer dar corpo a suas paixões, sem considerar a situação real. (Freud, 1912a/ 2010, p.146)

$\mathrm{Na}$ medida em que Freud se depara com a indiscutível presença desse fenômeno clínico, a busca por um passado perdido não se dá mais apenas pela recordação. Passa a ser papel do analista atentar-se também ao que aparece na relação ali presente e atual. Em "Recordar, repetir e elaborar" (1914b/2010), Freud fala um pouco sobre como isso apareceria na clínica. Ele diz: "Por exemplo: o analisando não diz que se lembra de haver sido teimoso e rebelde ante a autoridade dos pais, mas se comporta de tal maneira diante do médico." (Freud, 1914b/2010, p.200). Se tomamos novamente Dora como exemplo, podemos dizer então que suas idas e vindas do tratamento, bem como sua revelia, não eram outra coisa se não sua forma de recordar relações anteriores.

A transferência é, então, algo que se manifesta continuamente na clínica, podendo aparecer na expressão de afetos do paciente para com o analista, nas interrupções em sua associação livre e na repetição como alternativa possível a recordação. Freud (1912a/2010) afirma que todo silêncio ou pausa repentina seriam consequências dessa distorção da pessoa do médico. É que o analista, por mais neutro que se pretenda, acaba por inevitavelmente ocupar um - ou melhor, alguns - lugar na psique do paciente. Ainda que isso se apresente como resistência, se apreciada em seu caráter de repetição de relações passadas passa a ser um instrumento indispensável. Evidente que a transferência, a repetição, é efeito da resistência, mas não uma que impossibilita o trabalho, apenas uma que 
exige um olhar diferente - que trata a doença "não como assunto histórico, mas como um poder atual" (Freud, 1914b/2010, p.202).

Na medida em que os sintomas aparecem na esfera do tratamento, ou seja, se deslocam das vivências passadas para aquelas com o próprio médico, o processo analítico se transforma como que em uma arena na qual a doença pode se manifestar livremente. Freud (1914b) dirá que a neurose ordinária é então substituída por uma neurose de transferência, esta sim, passível de trabalho terapêutico. Tomemos a seguinte passagem para mérito de esclarecimento:

Assim a transferência cria uma zona intermediária entra a doença e a vida, através da qual se efetua a transição de uma para a outra. O novo estado assumiu todas as características da doença, mas representa uma enfermidade artificial, em toda parte acessível a nossa interferência. (Freud, 1914b/2010, p.206)

Antes de avançarmos para ainda um último momento do desenvolvimento da técnica na obra de Freud, devemos fazer um apontamento que nos será necessário nos próximos capítulos. Como vimos, Freud em nenhum momento fala dos sentimentos do analista ante o paciente, de forma que esta transferência é percebida como uma competência unilateral. O mesmo não será verdade para os autores por vir. Em suas obras iremos nos deparar com a noção de contratransferência, que explana o campo afetivo também por parte do analista. Como já havíamos adiantado, Ferenczi, Winnicott e Balint são teóricos que colocam não o funcionamento econômico do aparelho psíquico em destaque, mas a importância do entorno, do ambiente. Na situação analítica esse entorno inclui, necessariamente, a figura do analista. Este não está ali em uma função de objeto intermediário de descarga nem tampouco como espelho, mas como sujeito em relação. Assim, para esses autores a transferência nunca será compreendida de maneira isolada, mas como campo que permeia os dois sujeitos da relação terapêutica.

Tendo sido feita essa diferenciação devemos agora recorrer aos últimos artigos técnicos escritos por Freud nos anos que antecedem sua morte. São estes: “Análise terminável e interminável” (1937a/2018) e “Construções na análise" (1937b/2018). Assim como sua teoria referente ao funcionamento psíquico sofreu mudanças perante as novas sintomatologias expressas pelos 
neuróticos de guerra, evidente que também a técnica não pôde passar isenta. Diante dos fenômenos que funcionam além do princípio do prazer, há de se incluir na clínica as manifestações que não podem ser recordadas ou descarregadas sem antes serem ligadas. Estes elementos psíquicos que levam Freud a uma possível reinvenção da postura e das técnicas do analista, agregando a elas um caráter que podemos chamar de mais ativo.

Nos artigos citados, Freud debate sobre as dificuldades que percebe na clínica psicanalítica após todos esses anos de seu desenvolvimento. Qual seria, afinal, o trabalho do médico praticante de psicanálise? Seria ele atingível? Se sim, como? Ele fala em uma tarefa de "amansamento" (Freud, 1937a/2018, p.286) das pulsões, salientando as diferentes atuações no trabalho por parte do Eu e por parte do Id do paciente. Mas, sobretudo, fica a já conhecida tese de que o trabalho analítico depende da recordação de vivências antigas, sendo elas, ou melhor, o recalque das mesmas, as causas dos sintomas atuais. Resta saber de que forma estas são buscadas e como as resistências são enfrentadas.

A viabilização desse retorno é o que podemos designar como o trabalho do analista. Citando Freud, o trabalho do analisando é o de "ser levado a se recordar de uma coisa vivida e reprimida por ele" (Freud, 1937b/2018, p.329); enquanto sobre o analista diz: "Ele tem que adivinhar, ou melhor, construir20 o que foi esquecido, com base nos índices deixados" (Freud, 1937b/2018, p.329). Ou seja, para que o paciente possa trazer para a atualidade do tratamento estes valiosos pedaços de sua história, cabe ao analista lançar mão de ferramentas técnicas que preparem o campo para o retorno do recalcado. Até aí, falamos das antigas descobertas: da associação livre, da atenção flutuante, da transferência, da interpretação, etc. A novidade aqui parece circundar o que Freud chamou de “construção". Ele diz: "O efeito terapêutico está ligado à ação de tornar consciente o que no Id é reprimido no sentido mais amplo. Preparamos o caminho para esse tornar consciente com interpretações e construções" (Freud, 1937a/2018, p.306). $\mathrm{Ou}$ seja, as interpretações e as construções seriam as duas principais possibilidades de trabalho ativo por parte do analista.

${ }^{20}$ Grifo do original 
Mas o que seriam as construções e no que elas diferem das interpretações? Embora desde sempre presentes no método psicanalítico, talvez tenha sido só mais tarde em sua obra, após a elaboração do segundo dualismo pulsional, que Freud pôde atentar-se a esse instrumento. Pois se por um lado (das pulsões de vida) o ideal seria um equilíbrio energético, por outro (pulsões de morte) buscavase sobretudo o desligamento completo. Assim, a terapia psicanalítica ganha ainda outra tarefa, anterior àquela que, por assim dizer, despia o material psíquico consciente de seus disfarces. Frente às repetições não significadas, às manifestações de energias aparentemente desligadas, não seria suficiente a interpretação; antes da mesma, seria necessário transformar o material em uma narrativa passível de trabalho, queira, seria necessário uma construção. Comparando o trabalho do analista ao do arqueólogo, Freud nos presenteia com uma ilustração desta complexa tarefa: "E nossa comparação dos dois trabalhos chega ao fim, pois a principal diferença entre eles consiste em que, para a arqueologia, a reconstrução é a meta e o fỉm dos esforços, e, para a análise, a construção é apenas um trabalho prévio.” (Freud, 1937b/2018, p.332)

A partir da elaboração de Freud podemos concluir que a construção não resolve o trabalho, ela mesma não é capaz de tornar consciente as memórias esquecidas e dissolver o sintoma. Até porque, já concluímos, esse trabalho é do paciente. A construção é, porém, uma possibilidade de preparar o campo para a rememoração; ela propõe conteúdos e relembra pedaços da pré-história de forma a tornar a tarefa do paciente menos árdua. Afinal, diferentemente do arqueólogo, que reconstrói a partir de cinzas e fragmentos, o material psíquico a partir do qual o analista trabalha não está destruído, apenas profundamente escondido e tornado indisponível. Sendo essa a matéria bruta do trabalho analítico, o médico lança mão de diferentes instrumentos para torná-la atual. Apenas assim ela se torna passível de trabalho. Tomemos um exemplo de Freud:

Falamos ao paciente sobre a possibilidade de outros conflitos instituais e despertamos nele a expectativa de que tais coisas também possam lhe ocorrer. Esperamos que essa comunicação e advertência terão a consequência de ativar nele um dos conflitos insinuados, em grau modesto mas suficiente para o tratamento. (Freud, 1937a/2018, p.298) 
Por fim, devemos salientar dois últimos aspectos da introdução de uma construção no processo analítico. O primeiro é o debate com o qual Freud inicia o texto "Construções na análise" (Freud, 1937b/2018): o papel do "sim" e do "não" do paciente diante de um material apresentado pelo analista. Ora, não se trata da veracidade nem de um nem de outro, mas do que prossegue. O que confirma uma proposição por parte do analista não é um sim do paciente, mas uma evidente transformação do mesmo ou, ao menos, o despertar de um novo material. A segunda questão - e esta não é necessariamente proposta por Freud mas nos será necessária - diz respeito o papel da transferência, ou melhor, da contra transferência, nessas construções. Evidente que, segundo a regra da associação livre, o que será destacado ou interpretado pelo analista será consequência do estado adotado de uma atenção flutuante. Porém, na medida em que falamos dessas proposições mais ativas por parte do analista, será que não temos de levar em conta o lugar do qual ele fala? Será que, ainda assim, ele cabe na posição descrita como especular? Não poderemos resolver isso aqui mas veremos como este questionamento se torna caro no desenvolvimento do saber psicanalítico.

Finalizando a trajetória técnica de Freud podemos concluir que mesmo quando fala, nesses últimos textos, de uma função mais ativa e ampla do analista, ele se atém a um olhar da psicanálise que coloca como sua tarefa principal a rememoração, o tornar consciente, e os instrumentos utilizados só se justificam na medida em que facilitam a realização desse trabalho específico. Entretanto, muitos dos aspectos que nos serão importantes para compreender a visão clínica de Ferenczi, Winnicott e Balint já podem ser observados na obra freudiana, ainda que de forma embrionária. Destaquemos em específico a importância atribuída à atuação de vivências passadas na transferência, por parte do analisando, e às construções em seu aspecto anterior às interpretações por parte do analista.

Um último ponto deve ser lembrado como forma de despedida da leitura de Freud: a dimensão exclusivamente intrapsíquica da regressão. Embora tenhamos falado das repetições na relação analítica, ora, do retorno ao passado via transferência, o caráter intrapsíquico desse funcionamento nunca foi desconstruído. A regressão permaneceu compreendida, sobretudo, como sentido 
tomado pelas energias psíquicas seja na formação do sintoma, nas produções oníricas ou no aspecto conservador e disjuntivo das pulsões. Entrando no pensamento ferencziano devemos nos preparar para grandes mudanças. $\mathrm{O}$ analista é convocado a sair do espelho. 


\section{3.}

\section{Regressão na obra de Sándor Ferenczi: a possibilidade de uma dimensão terapêutica}

As primeiras investigações teóricas de Ferenczi já parecem expressar, ainda que discretamente, algumas discrepâncias da teoria de seu mestre Freud. Já em seu primeiro trabalho publicado, "Do alcance da ejaculação precoce" (Ferenczi, 1908/2011), o húngaro, ao olhar para o sofrimento da mulher a partir da ejaculação do homem, deixa transparecer sua forma criativa de perceber as experiências humanas. Segundo Borgogno (1998/2004), já aí ele expõe uma orientação decididamente relacional e, assim como olhou para a mulher, é ele quem primeiro olha para as crianças na análise de adultos, para os pacientes não-neuróticos e, sobretudo, para o próprio analista na relação com o paciente. Um dos aspectos mais interessantes da trajetória de Ferenczi talvez seja a forma como ele pôde, ao menos por muito tempo, se manter próximo de Freud (diferentemente de tantos outros de seus alunos) e ainda assim traçar um caminho absolutamente inovador.

Esse aspecto relacional de sua obra irá nos introduzir a um caminho no qual focaremos daqui pra frente. É a partir de Ferenczi que tantos outros autores passarão a pensar a relação analítica incluindo a subjetividade do analista enquanto elemento fundamental e, na medida em que o fazem, pesquisarão o conceito de contratransferência, apenas meramente citado em Freud. Essa adição da vida psíquica do analista ao trabalho terapêutico é, sobretudo, uma postura que explicita o que, segundo Costa (1995), é o único imperativo que orienta sua teoria, este é, o imperativo da ética.

Para falarmos especificamente da regressão na obra de Ferenczi percorreremos a todo momento a teoria e a prática clínica. Isso nos é caro porque, como o psicanalista húngaro fazia questão de lembrar, sua teoria existe para dar conta do que aparece na prática, de forma que podemos afirmar ser sua obra - em grande parte - uma teoria sobre a clínica. De todo modo, já que há de ser escolhido um ponto de partida, visitaremos primeiro sua compreensão sobre o 
desenvolvimento e a constituição subjetiva. Antes de falarmos de seu manejo técnico precisamos saber como ele enxerga o sujeito que chega e se cria na análise e que pontos do desenvolvimento são concebidos como indispensáveis para uma apreensão do funcionamento psíquico.

\section{1}

\section{A regressão "bioanalítica"}

O texto com o título de "Thalassa, ensaio sobre a teoria da genitalidade" (Ferenczi, 1924c/2011), além de ser, segundo Freud, o mais genial dos trabalhos de Ferenczi, ilustra a originalidade que lhe é comumente atribuída. Nomeado em tributo à deusa grega que personifica o oceano, o texto articula, em uma complexa e detalhada exploração, o desenvolvimento ontogenético e filogenético, constituindo um campo que Ferenczi chamou de "bioanalítico". Dentre os muitos diálogos encontrados no texto sobressaem o texto freudiano de 190521, sobre o desenvolvimento sexual, e a filogênese de Lamarck22, de forma que há, em todas as páginas, a tentativa de traçar paralelos entre a evolução do indivíduo enquanto sujeito, a evolução do indivíduo enquanto ser biológico desde a vida embrionária e a evolução das espécies que habitam a Terra. Um projeto, além de original, inegavelmente ambicioso.

Para abordar as origens da vida sexual e as diferenças entre o homem e a mulher, Ferenczi parte no texto da ideia de que o desenvolvimento - filo, onto e perigenético - se dá em função de catástrofes. Ele lista cinco grandes catástrofes dentre as quais talvez a principal seja, na esfera filogenética, a emergência dos continentes e, na esfera ontogenética, o nascimento. Entende-se que a segunda é, na verdade, uma repetição da primeira. Para todas as cinco catástrofes que marcaram a história das espécies há uma equivalência no indivíduo. Esta equivalência se dá não por analogia mas, como afirma Pinheiro (1995), por efetiva repetição biológica. Ela diz: “O estabelecimento desta relação, ou seja, de uma

\footnotetext{
${ }^{21}$ Freud, S. (1905b/2016) Três ensaios sobre a teoria da sexualidade. 22 Jean Baptiste de Lamarck (1744-1829), naturalista francês que estudou a evolução dos seres vivos.
} 
ontogênese que nada mais faz do que repetir o desenvolvimento filogenético, equivale a dizer que todo desenvolvimento é uma repetição, ou seja, cada conquista é na verdade repetição de uma catástrofe já ultrapassada" (Pinheiro, 1995b, p.30).

Como já foi o caso ao apresentarmos o segundo dualismo pulsional de Freud, quando se fala em repetição pergunta-se também sobre um aspecto regressivo. Em Thalassa, este vai ser explicitado através do esforço de Ferenczi em aprofundar um entendimento do ato genital do coito. Enquanto na obra de Freud o ato do coito em si é algo pouco explorado, sendo contemplado, sobretudo ,como meta final da sexualidade, Ferenczi (1924c/2011) se questiona sobre esse lugar de destaque. A partir da ideia de que a vida sexual humana repete o desenvolvimento filogenético, a pergunta poderia ser formulada da seguinte maneira: O que buscamos repetir no ato do coito? Recorremos, mais uma vez, às palavras de Pinheiro (1995):

$\mathrm{O}$ coito seria não apenas a prática sexual do estágio genital mas, também e principalmente, uma forma de repetir a batalha travada no momento da emergência dos continentes. Esse trauma teria necessidade de ser repetido para ter um final feliz. O coito, expressão da sexualidade genital, reúne, segundo Ferenczi, um universo complexo de símbolos e de traumas, e também as características das pulsões parciais. (Pinheiro, 1995b, p.31)

Um primeiro aspecto da repetição presente no coito a ser enfatizado é o que Ferenczi (1924c/2011) chamou de "anifimixia", que quer dizer que, no coito estariam presentes todas os outros vários erotismos. Nesse sentido ele funcionaria, para usar um termo biológico, de maneira "pangenética" - em alusão ao continente Pangeia23. Ferenczi diz que "todas as partes do organismo estão, de um modo ou de outro, representadas no aparelho genital" (Ferenczi, 1924c/2011, p. 290), de forma que este nível da sexualidade repetiria de forma concentrada todas as outras experiências sexuais do desenvolvimento. Cabe à genitalidade "reagrupar de maneira regressiva as pulsões parciais" (Pinheiro, 2016, p.86).

Mas há ainda um segundo aspecto que nos será especialmente caro. Ferenczi (1924c/2011) propõe ser através do coito a manifestação maior de uma

\footnotetext{
23 Designa-se por Pangeia a massa continental que supõe-se ter existido aproximadamente 200 milhões de anos atrás. Ela reuniria todos os continentes que hoje concebemos como separados.
} 
“pulsão de regressão materna”. Ou seja, o encontro dos órgãos genitais e, em especial, a "aquosidade" na qual se dá este encontro, resultaria na sensação desejável de retorno à vida intra-uterina. Esta ideia de uma regressão ao ventre materno já havia sido apresentada em 1913 no texto "Desenvolvimento do sentido de realidade e seus estágios" (Ferenczi, 1913a/2011) enquanto um desejo ativo em todo sujeito. A vida intrauterina, em condições ideais, seria, para Ferenczi, o ápice do princípio de prazer, a onipotência incondicional a qual se tenta retornar pelo resto da vida. Como veremos em seguida, esta ideia é desenvolvida no texto de 1913 sob a ótica do desenvolvimento do ego levando em conta sua relação com o meio. Em Thalassa, esta pulsão universal é projetada nos estágios da sexualidade.

Se considerarmos agora toda a evolução da sexualidade, desde a sucção do polegar do bebê até o coito heterossexual, passando pelo narcisismo da masturbação genital, e se tivermos em mente os processos complexos de identificação do ego com o pênis e com a secreção genital, chegaremos à conclusão de que toda essa evolução, incluindo, por conseguinte, o próprio coito, só pode ter por objetivo final uma tentativa do ego, no começo hesitante e canhestra, depois cada vez mais decidida e, por fim, parcialmente alcançada, de regressar ao corpo materno, situação em que a ruptura tão dolorosa entre o ego e o meio ambiente não existia ainda. (Ferenczi, 1924c/2011, p.292)

Comparando o ato sexual em questão ao desenvolvimento filogenético, Ferenczi entende que alí estaria atuando a "repetição, ao nível individual, da luta entre os sexos" (Ferenczi, 1924c/2011, p.299). Nessa luta, o homem é quem tem a meta alcançada mais explicitamente. Ao penetrar o corpo da mulher, ele, que tem seu ego representado de maneira concentrada no órgão sexual, retorna ao meio aquoso no qual foi gestado. A mulher é ao mesmo tempo mãe e símbolo do oceano perdido da história contada sobre a vida na Terra. Mas no ato sexual ela atinge o seu retorno apenas por um caminho secundário, mais complexo, “contentando-se por sua parte com compensações fantasísticas e, sobretudo, acolhendo a criança de cuja felicidade compartilha" (Ferenczi, 1924a/2011, p. 299).

Durante o coito, o homem regride até tornar-se um feto no ventre de sua mãe, encontrando alí aquele meio que o engolfa. Estará também imerso de novo no meio aquático, no oceano anterior ao advento dos continentes. Segundo Ferenczi, a mulher, no coito, identifica-se com o homem que tem o pênis e pode, na 
penetração, encontrar também o útero materno e o oceano perdido ${ }^{24}$. Além disso, ganha a esperança de ter um filho. (Pinheiro, 1995b, p.32)

O momento da fecundação, do desenvolvimento do embrião no útero materno, equivaleria, na filogenia, ao início da reprodução sexuada a partir da luta dos sexos. Esses acontecimentos correspondem à terceira catástrofe elencada por Ferenczi, última antes da importante emergência dos continentes e do trauma inevitável do nascimento. Assim, “o coito é também a repetição que visa liquidar os traumas em virtude das sucessivas catástrofes, desde o traumatismo do nascimento, catástrofe individual, até a catástrofe da emergência dos continentes que obrigou ao acasalamento" (Pinheiro, 2016, p.86/7).

Evidente que esta é uma apresentação simples de um texto de densidade importante mas a nós parece que, se dois pontos forem exaltados, esse percurso mais breve terá sido suficiente. O primeiro ponto a ser salientado é a inovação ferencziana de perceber no coito uma força regressiva. $\mathrm{O}$ ato do coito, antes tido como meta principal a qual todas as anteriores eventualmente se submetiam, passa a ser percebido em sua qualidade regressiva. Assim, o ato genital, antes soberano e final, passa a ser um meio e não um fim.

A segunda questão é a exaltação da regressão ao útero materno enquanto força universal e fundante no psiquismo. Mais uma vez Ferenczi se coloca de maneira alternativa a Freud que, ao pensar uma força regressiva, destacara o desejo de retorno ao inanimado. Embora essas ideias sejam semelhantes, um olhar mais atento explicita importantes diferenças. A regressão descrita por Freud é expressa na compulsão à repetição, representa uma faceta da pulsão de morte, tem como mecanismo o desligamento e como meta uma ausência de tensão, um retorno ao inanimado. A regressão materna de Ferenczi, embora também fale em um "nirvana", não o faz pensando em um desligamento mas em uma profunda união e harmonia, uma indiferenciação entre o ser e o meio de modo a tornar o primeiro onipotente.

Começamos este capítulo de Ferenczi, portanto, com um texto que nos coloca em direto contato com sua forma de pensar. Um olhar ampliado ocupado com os símbolos mas também com o corpo biológico. Uma teoria que, e isso nos

${ }^{24}$ Grifo do original. 
importa em especial, coloca os primórdios em destaque. Veremos ainda como essa abertura para o novo que é característica do autor se materializará nas outras temáticas de sua obra.

\section{2}

\section{O desenvolvimento do ego na teoria ferencziana}

Um ano antes de Freud publicar "Introdução ao narcisismo" (1914a/) Ferenczi já escrevia sobre a constituição egóica e pontuava, nesse desenvolvimento, estágios aos quais os neuróticos pareciam regredir. Por um lado seguia o pensamento apresentado por Freud em "Três ensaios da teoria da sexualidade" (1905b/2016) e explicava o sintoma neurótico a partir de uma fixação em um momento do desenvolvimento mas, por outro, falava não apenas no desenvolvimento sexual mas também em um desenvolvimento do ego em relação ao ambiente. Para ele, o problema que Freud colocara sobre a ascensão do princípio de realidade sobre a satisfação sexual devia ser pensado de forma gradativa e de maneira menos estritamente intrapsíquica. Em "O desenvolvimento do sentido de realidade e seus estágios" (1913a/2011) Ferenczi descreve, portanto, as etapas que constituintes dessa passagem de um primado do princípio de prazer a uma submissão do mesmo ao princípio de realidade, explicitando também o que cada um desses princípios representaria enquanto tendência psíquica.

Começaremos pelo ponto de partida tomado por Ferenczi, já aí distinto daquele apresentado por Freud. Falamos da experiência intrauterina do bebê. Esse momento da subjetividade representaria o primeiro estágio e, ora, aquele ao qual todo indivíduo "secretamente" deseja retornar. Trata-se de um período da existência marcado pela total e real onipotência, ao qual Ferenczi dará o nome de "período da onipotência incondicional" (Ferenczi, 1913a, p.49). Para uma melhor compreensão podemos usar a definição que Ferenczi apresenta para a ideia de onipotência: "É a impressão de ter tudo o que se quer e de não ter mais nada a desejar." (Ferenczi, 1913a, p.48). Ou seja, no período citado, não havendo nenhum infortúnio na gestação, o bebê se encontra em um estado de plenitude no 
qual tudo que deseja se realiza instantaneamente, de forma que ele sequer precisa desejar; o mundo parece existir em função de suas necessidades. Para usar um termo balintiano que veremos no próximo capítulo, vive-se em perfeita "harmonia".

É empiricamente evidente, entretanto, que esse estado não dura muito tempo. Na medida em que o ser se desenvolve e os desejos se tornam cada vez mais complexos, torna-se impossível para o meio sustentar essa ilusão de onipotência. Assim, os estágios que seguem são delimitados em função da maneira como está balanceada a crença na própria onipotência e a possibilidade de afirmação do desprazer. Ou seja, nos termos freudianos, em que passo está a transição da soberania do "princípio de prazer" para o reconhecimento do “princípio de realidade". Quanto mais cedo no desenvolvimento, mais se tenta preservar ou retornar a esse estado de real onipotência, mas esta já não é mais atingível senão de maneira ilusória.

Ainda assim, nota-se na relação entre os cuidadores e os recém-nascidos uma tentativa por ambas as partes de forjar essa onipotência, ou seja, de reaproximar, ao máximo, as sensações do bebê àquelas do estado ideal abandonado. O indivíduo afasta e nega os desprazeres que atestam uma realidade externa e indiferente a ele de forma a seguir acreditando em sua onipotência. Tendo suas demandas atendidas quase de imediato, o bebê consegue acreditar que a realidade funciona de maneira mágica. A este período Ferenczi (1913a/2011) deu o nome de "período da onipotência alucinatória mágica".

Os períodos que seguem apontam para uma dificuldade cada vez maior em sustentar a crença na onipotência e explicitam os recursos que vão sendo desenvolvidos como meios de assegurar essa ilusão. Primeiro podemos falar em um "período da onipotência com ajuda dos gestos mágicos", no qual o indivíduo descobre ações com o próprio corpo que facilitam o atendimento de suas necessidades e a satisfação de seus desejos. Talvez o mais importante a se dizer sobre essa fase seja o fato de ser a ela que Ferenczi atribui a regressão histérica. Ora, como já vimos, "segundo a psicanálise, as crises histéricas representam, com a ajuda de gestos, a realização de desejos recalcados", diz Ferenczi (1913a/2011, 
p.53). Em Freud vimos como as zonas histerógenas se assemelham às erógenas, no sentido de serem marcadas; e como o sintoma histérico representa uma solução de compromisso para obtenção de prazer. O que Ferenczi aponta então é que esse mecanismo da histeria, de fazer uso do corpo material para realizar o desejo, remonta a este período dos "gestos mágicos" do desenvolvimento do ego.

Ferenczi fala brevemente em um "período animista", que seria basicamente a atribuição de ações humanas aos objetos, indicando uma maior relação do eu com os objetos externos. E, em seguida, descreve o "período dos pensamentos e palavras mágicas", que nos será de grande importância para compreender a neurose obsessiva - condição da qual Ferenczi parte no início do texto. Nesse período o indivíduo estaria no início de uma apreensão da linguagem, dos signos e, portanto, dos pensamentos. Segundo o autor, o efeito disso na criança seria a ilusão de que o ambiente, de alguma forma mágica, tem acesso aos seus pensamentos já que, tratando-se de fórmulas ainda suficientemente simples de desejo, basta ele pensar para que a coisa se concretize. Daí a relação com o sintoma obsessivo, que explana a onipotência atribuída aos pensamentos. Nas palavras de Ferenczi: “O obsessivo, constatará o analista, tem a impressão de que a felicidade e a infelicidade dos outros, inclusive sua vida e sua morte, dependem de algumas de suas ações e de seus processos de pensamento, inofensivos em si mesmos.” (1913a/2011, p.46)

Começamos falando sobre como nesse texto Ferenczi descreve um desenvolvimento como Freud fizera, outrora, em "Três ensaios da teoria da sexualidade" (1905b/2016). Importante dizer, porém, que, segundo o húngaro, não se trata de uma substituição mas de uma coexistência dos processos, por um lado uma linha de desenvolvimento sexual e por outro um desenvolvimento do ego. Mais ao final do artigo de 1913 ele discorre sobre os pontos de convergência e divergência entre esses caminhos paralelos e aponta como podemos percebê-los nas manifestações neuróticas. Ele diz:

De acordo com a nossa hipótese, o teor em desejos da neurose, ou seja, os modos e os objetivos eróticos que os sintomas representam como consumados, dependem da fase em que se encontrava o desenvolvimentos da libido no momento da fixação; quanto ao mecanismo das neuroses, é provavelmente determinado pelo estágio de desenvolvimento do ego em que o indivíduo se 
encontrava no momento da inibição predisponente. (Ferenczi, 1913a/2011, p. $59) 25$

Sustenta-se a teoria de Freud de que a forma da neurose decorre da fixação em determinada fase do desenvolvimento da libido mas a isso é acrescido o elemento do mecanismo via qual o ego neurótico se relaciona com a realidade. Falamos por um lado de manifestações sexuais e por outro de manifestações do ego. Porém, sobressai sempre a ideia de haver, na história do sintoma, um ponto de fixação ao qual se regride, seja libidinalmente ou egoicamente. Acrescentamos as palavras de Ferenczi extraídas do texto "Fé, incredulidade e convicção sob o ângulo da psicologia médica" (1913b/2011):

Mas cada etapa transposta ao longo do rude caminho da evolução pode exercer uma influência decisiva sobre a vida psíquica, criar um ponto vulnerável, um lugar de fixação a que a libido é sempre suscetível de regredir e que será reencontrada, portanto, em certas manifestações da vida posterior. (Ferenczi, 1913b/2011, p.35)

Mas Ferenczi acrescenta ainda, no texto de 1913 antes citado ${ }^{26}$, um terceiro elemento do qual lança mão para distinguir as neuroses e os estágios do desenvolvimento, este seria a predominância da introjeção ou da projeção enquanto mecanismo psíquico. Segundo ele, no primeiro estágio, o da onipotência, haveria uma hegemonia do mecanismo da introjeção, que Ferenczi definira como o processo de tornar as coisas do mundo suas, uma "introdução dos objetos externos na esfera do ego" (Ferenczi, 1912a/2011, p.209). Já num segundo momento, que podemos associar à realidade, o processo da projeção entra em jogo de maneira mais proeminente e, assim, passa a acontecer uma atribuição de sensações e experiências particulares aos objetos externos. Aproveitamos a introdução desses dois conceitos para ingressarmos em outro aspecto da constituição subjetiva descrita pelo autor húngaro.

Antecipando-se à publicação freudiana de 1912²7, Ferenczi (1909/2011) publica um primeiro artigo ${ }^{28}$ sobre o fenômeno da transferência. Antes de

\footnotetext{
25 Grifos do original

${ }^{26}$ Ferenczi, S. (1913a/2011). Desenvolvimento do sentido de realidade e seus estágios

${ }^{27}$ Freud, S (1912a/2010) A Dinâmica da transferência

${ }^{28}$ Ferenczi,S (1909/2011). Transferência e introjeção
} 
adentrarmos a questão da técnica, importa dizer que Ferenczi (1909/2011) percebia a transferência como atuante em todos os campos da vida e que ela seria, na verdade, apenas o "exagero" do mecanismo primitivo da introjeção. Tudo que veremos sobre como o paciente se relaciona com os seus objetos e, dentre eles, o analista, seria uma repetição das primeiras relações objetais do sujeito, estas, portanto, constituintes. "O primeiro amor objetal ${ }^{29}$, o primeiro ódio objetal ${ }^{30}$ constituem, portanto, a raiz, o modelo de toda transferência posterior, que não é, por conseguinte, uma característica da neurose, mas a exageração de um processo mental normal.” (Ferenczi, 1909/2011, p.96).

Vejamos, o que quer dizer um ódio ou um amor primeiro? Ora, assim como temos em Freud (1915a/2010)31 como destinos primitivos da pulsão a atribuição ao mundo externo e a volta contra a própria pessoa, Ferenczi (1909) também fala sobre esse movimento pendular entre o dentro e o fora mas o faz, não via um pensamento pulsional, mas se atendo, sobretudo, ao processo de constituição do ego. Assim, à ideia de "primeiro ódio" atribuímos o mecanismo da “projeção primitiva” (Ferenczi, 1909/2011, p.96), na qual indivíduo expulsa parte de sua experiência - processo fundamental para a separação entre o Eu e o mundo. Já o "primeiro amor" nos faz pensar na "introjeção primitiva" (Ferenczi, 1909/2011, p.96), quando o ser pode expandir-se incorporando ao seu ego objetos do mundo. Estes dois processos serão fundamentais para Ferenczi pensar as diferenças básicas entre o paranoico e o neurótico:

enquanto o paranoico projeta no exterior as emoções que se tornaram penosas, $\mathrm{o}$ neurótico procura incluir em sua esfera de interesses uma parte tão grande quanto possivel do mundo externo ${ }^{32}$, para fazê-lo objeto de fantasias conscientes e inconscientes. [...] Proponho que se chame introjeção a esse processo inverso da projeção. (Ferenczi, 1909/2011, p.95)

Mais tarde, e de maneira especialmente autoral, Ferenczi (1933/2011) recorrerá a esse mesmo conceito para descrever o trauma como uma vivência marcada, dentre outras coisas, pela “introjeção do agressor".

\footnotetext{
${ }^{29}$ Grifo do original

${ }^{30}$ Grifo do original

${ }^{31}$ Freud, S. (1915a/2010). A pulsão e seus destinos.

${ }^{32}$ Grifo do original
} 
Seguindo na tentativa de compreender o desenvolvimento e seus impasses para Ferenczi, precisaremos aproximar-nos de outro tipo de sintoma que não o obsessivo ou o histérico já abordados. Trabalhando em um hospital geral durante a Primeira Guerra Mundial, Ferenczi teve a oportunidade de entrar em contato com distúrbios muito além daqueles que chegavam aos consultórios de uma ainda incipiente psicanálise e, assim, se configura o nascimento de uma clínica não neurótica. Falamos, em especial, dos casos de neurose de guerra. A partir do contato com esses homens que voltavam do combate Freud (1920/2010) desenvolvera o segundo dualismo pulsional e Ferenczi passara a pensar clinicamente o que viemos a conhecer como os sofrimentos narcísicos.

Mas não foi apenas a partir dos casos de neurose de guerra que Ferenczi pôde perceber as afetações derivadas do processo de constituição egóica. Também os tiques ele perceberá como sintoma de origem narcísica. Em ambas condições encontramos as origens da - mais tarde melhor formulada - noção de clivagem enquanto processo psíquico que opera enquanto uma defesa diferente da do recalque. No texto de 1921, "Reflexões psicanalíticas sobre os tiques", temos a seguinte passagem: "seria necessário supor um conflito interior do ego (entre o núcleo do ego e o narcisismo) e de um processo análogo ao recalcamento". Fica evidente a percepção da existência de um mecanismo psíquico que diz respeito mais a uma falha constitucional do que a um conflito econômico.

Em suas reflexões sobre as neuroses de guerra Ferenczi (1916/2011) acrescenta um novo fator ao que Freud (1920/2010) já pontuara sobre esse tipo de adoecimento. Além do elemento do choque ou surpresa no momento do trauma, ele fala em um abalo da confiança em si mesmo, em uma "lesão do ego" (Ferenczi, 1916/2011, p.309). Seu desenvolvimento vai, portanto, no sentido de compreender como consequência da vivência traumática uma perda da autoconfiança, da certeza de si. Pensando o sintoma característico desses neuróticos, de uma marcha particularmente rígida e involuntária, Ferenczi diz: "Parece que o estágio para o qual esses dois neuróticos ${ }^{33}$ regrediram é o primeiro ano, em que não se sabe ainda ficar de pé nem andar corretamente" (1916/2011, p.

\footnotetext{
${ }^{33}$ Aqui o autor faz referência a dois casos de neuróticos de guerra que ele usara como exemplo.
} 
305). Embora ele esteja falando de uma experiência concreta, não parece absurdo tomarmos essa afirmação no seu sentido metafórico e compreendermos que esses soldados traumatizados perdem a confiança necessária para ficarem de pé e andarem por si mesmos. A perda da confiança em si os deixa impossibilitados de agirem, imobiliza seus corpos.

Recorrendo ao trabalho do psicanalista italiano Franco Borgogno (1997/2004) sobre a neurose de guerra descrita por Ferenczi, podemos pensar os sintomas somáticos evidentes nesse tipo de quadro como uma aparição no corpo daquilo que não pôde ser representado psiquicamente. É nesse aspecto que uma paralização traumática difere de uma conversão histérica. Enquanto a primeira exprime uma experiência não nomeada, a segunda fala de um deslocamento em função do mecanismo neurótico do recalcamento. Uma "petrificação" em oposição a uma "condensação". As consequências disso, nas palavras de Borgogno, são:

Nestas circunstâncias, até mesmo o próprio organismo e a o própria mente podem ser tratados como estranhos e perigosos, daí a única aspiração transformar-se, em casos extremos, na imobilidade absoluta, semelhante à morte, a qual protege do sofrimento e da injúria insustentáveis. Uma espécie de suicídio psíquico que, na realidade, é revolta furiosa ${ }^{34}$ contra tudo e todos, inclusive a si próprio. (Borgogno, 1997/2004, p.176)

No artigo do qual a citação foi retirada o raciocínio a respeito dos neuróticos de guerra serve para endossar a teoria do trauma de Ferenczi, que veremos no último item deste capítulo.

Se articulamos essa ideia ao que vimos sobre o processo de desenvolvimento do ego e a báscula entre investimento no eu e no mundo via os processos de introjeção e projeção, percebemos que na neurose traumática aparece, em consequência dessa perda de autoconfiança, um intenso reinvestimento no próprio eu como forma de defesa. Fala-se em uma regressão narcísica como resposta a um trauma que colocara em ameaça a continuidade de existência do eu. Não à toa, os sintomas presentes neste tipo de neurose apontam para o que Ferenczi (1918a/2011) chamou de uma "hipersensibilidade do ego".

\footnotetext{
${ }^{34}$ Grifos do original
} 
Ligando os dois pontos, citemos o próprio: "Essa hipersensibilidade provém de que o paciente - em consequência de um choque ou de uma série de choques retirou dos objetos seu interesse e sua libido para concentrá-los no ego" (Ferenczi, 1918a/2011, p.28).

Assim, Ferenczi (1916/2011) inicia seus estudos sobre a neurose de guerra localizando-a em uma interseção entre a histeria de angústia e a histeria de conversão ${ }^{35}$, e avança para uma compreensão que a associa mais a uma regressão do eu que leva o doente a se portar como uma "criança mimada". O retorno de seus investimentos para o próprio eu atuariam no sentido de, em decorrência de um susto, proteger-se das surpresas do ambiente: "o motivo primário da doença é o próprio prazer de permanecer no seguro abrigo da situação infantil, outrora abandonada a contragosto" (Ferenczi, 1916/2011, p.29).

Podemos pontuar neste tipo de observação o gérmen da regressão enquanto ferramenta terapêutica. É a partir da compreensão da necessidade de um cuidado infantil deste tipo de paciente que Ferenczi poderá considerar os efeitos por vezes agressivos da postura do analista. Esse ego que aparece em destaque nos sintomas dos neuróticos traumáticos deixa de ser visto apenas como um funcionamento histérico para poder ser percebido como uma regressão narcísica, tornada necessária a partir de um abalo excessivo - insustentável - para a continuidade do sujeito.

A neurose traumática resulta de um choque psíquico e físico intenso, sem ${ }^{36}$ lesão corporal importante. Sua sintomatologia combina a regressão narcísica (abandono de uma parte dos investimentos de objeto) e os sintomas da histeria de conversão ou de angústia, que classificamos, como se sabe, entre as neuroses de transferência. (Ferenczi, 1917/2011, p.336).

Retomando a questão dos portadores de tiques, podemos de antemão elencar dois pontos que Ferenczi aponta como comuns entre eles e os neuróticos traumáticos: 1- uma identificação do ego com uma parte do corpo e; 2- um

\footnotetext{
${ }^{35}$ No texto "Dois tipos de neurose de guerra (histeria)" (1916a/2011) Ferenczi fala desses dois aspectos das neuroses de guerra. À histeria de angústia ele atribui o aspecto de produção de angústia como reação a um fator externo impassível de representação, presente, por exemplo, nos sonhos traumáticos; e à histeria de conversão a presença dos sintomas corporais como fixação no corpo, e não no psiquismo, de uma vivência traumática.
}

${ }^{36}$ Grifos do original 
infantilismo psíquico. Ambos remetem a expressões de neuroses de caráter narcísico e não, como na histeria e na neurose obsessiva, de transferência. O que isso anuncia é que o tipo de sintoma manifesto por essas duas condições não são da ordem da relação com o outro, da introjeção da relação com o analista, mas apontam antes para uma falha na relação com o próprio eu, na sua constituição, seu narcisismo.

No texto de 1921, "Reflexões psicanalíticas sobre os tiques", Ferenczi explicita essa comparação entre os tiques e o sintoma histérico a partir do lugar comum das manifestações corporais; e o sintoma do ritual do obsessivo pela característica comum da repetição involuntária de certos atos. Mas deixa claro que, embora apresentem semelhanças quando observados externamente, diferem em seu funcionamento:

A histeria é uma neurose de transferência na qual a relação libidinal com o objeto (a pessoa) foi recalcada e retorna, de algum modo, no sintoma de conversão sob a forma de simbolização autocrítica do próprio corpo. No tique, pelo contrário, não parece existir relação de objeto dissimulada por trás do sintoma; por conseguinte, é a lembrança do próprio traumatismo orgânico ${ }^{37}$ que, neste caso, tem um efeito patogênico. (Ferenczi, 1921/2011, p.94)

Se pensamos pelo viés apresentado no texto dos estágios do desenvolvimento do sentido de realidade, cabe entender que o sintoma da ordem do trauma (do neurótico de guerra e dos portadores de tiques) representa uma regressão narcísica a um momento no qual a compreensão de um objeto externo ainda é falha. Nesses sofrimentos, o próprio corpo, ou parte dele, é tomado como objeto patogênico. É esse raciocínio que leva Ferenczi a pensar em um "sistema mnêmico do ego" (Ferenczi, 1921/2011, p.94) que seria responsável pelos registros tanto psíquicos quanto somáticos e sob o qual incindiria uma fixação corporal no momento do trauma. O conflito nesse tipo de patologia seria, portanto, entre "duas partes" do próprio eu.

É claro que, pela obra freudiana, não devemos esquecer a sexualidade presente no narcisismo. Segundo Freud (1914), é o investimento libidinal no próprio eu que permite sua constituição, ou seja, o nascimento do eu deriva de sua

${ }^{37}$ Grifos do original 
erotização. Porém, o que Ferenczi traz nas contribuições apresentadas aponta para casos nos quais os sintomas não se enquadram no sistema freudiano que os compreende como solução de compromisso entre instâncias psíquicas. Não se trata de resultantes da operação básica da neurose, do recalque, nem tampouco de sintomas que se explicitam na relação do sujeito com o outro - o que implica uma já madura relação de amor objetal. O que Ferenczi (1916a/2011; 1917/2011; 1918a/2011; 1921/2011) infere é que em certas manifestações sintomáticas o conflito percebido se dá na ordem de um embate na própria formação egóica e, nesse sentido, leva à necessidade de se pensar mecanismos análogos ao recalque, pois este se torna insuficiente. Mesmo o narcisismo, a erotização do eu, passa a parecer otimista diante de indivíduos que apresentam fixações e oposições inerentes a esta instância.

Ainda assim, Ferenczi ainda tenta enquadrar as expressões desses "pacientes difíceis" no sistema freudiano e chega a falar dos tiques e da catatonia como uma "histeria do ego", na medida em que "são autoerotismos que, em certa medida, adotaram qualidades genitais" (Ferenczi, 1921/2011, p.111). Evidente porém que, em seu "autoerotismo", apontam para condições mais relacionadas ao processo do narcisismo do que ao edípico, ao qual estariam associadas as expressões sexuais do amor objetal.

No decorrer do capítulo nos aprofundaremos na teoria da traumatogênese desenvolvida por Ferenczi a partir da década de 1920, o que nos trará respostas às questões apresentadas; mas, por ora, basta a compreensão de que certos sintomas parecem desafiar o sistema do recalque desenvolvido por Freud. Este, é claro, não é invalidado, mas, ao priorizar o desenvolvimento do ego, Ferenczi se aproxima de uma nova classe de sofrimentos que não pode ser enquadrada no espectro do complexo de Édipo e da angústia de castração. O conflito entre prazer e realidade, a partir do qual iniciamos essa discussão, ganha uma nova camada de complexidade: Ferenczi propõe que este desenvolvimento tem suas implicações na constituição do eu e em sua relação com os objetos do mundo, não sob um aspecto meramente pulsional mas também se levarmos em conta as qualidades desses objetos. 
Pela primeira vez na psicanálise, como se pode notar, passa-se a pensar nos sofrimentos narcísicos e em uma outra clínica, certamente não neurótica, na qual a regressão ocupa um lugar fundamental. Evidentemente, as implicações dessas descobertas ultrapassam a teoria. $\mathrm{Na}$ medida em que os pacientes apresentam sintomas para além da compreensão oferecida pelo modelo freudiano, a técnica tradicionalmente empregada em casos de neurose também se mostra obsoleta.

\section{3}

\section{A técnica ativa: uma ampliação da técnica clássica}

Em 1931, com uma trajetória clínica já bastante estabelecida, Ferenczi formula construções psicanalíticas que consolidam seu lugar como analista de casos difíceis e, mais do que isso, como um inovador no campo da técnica. Problemas colocados por Freud como possíveis limites do trabalho terapêutico - a resistência, o narcisismo e a estagnação - são por Ferenczi definidos como inadmissíveis; "enquanto o paciente continua comparecendo, o fio da esperança não se rompeu." (Ferenczi, 1931/2011, p.81). Acreditando na continuidade do vínculo como base necessária e suficiente para o trabalho terapêutico, o psicanalista húngaro dedicou sua carreira a esses casos que, embora “particularmente difíceis” (Ferenczi, 1931/2011, p.81), mostravam também se beneficiarem de um manejo psicanalítico. Este manejo não seria, entretanto, o mesmo apresentado na teoria freudiana, mas sim uma versão ampliada da técnica tradicional.

Encontramos no trabalho do espanhol José Jiménez Avello (1998) uma divisão da evolução da técnica desenvolvida por Ferenczi em etapas. A primeira, que data de 1908 a 1918, representaria seu período adepto à técnica clássica, embora, já aí, seja possível encontrar prenúncios de seus futuros trabalhos mais autorais. No texto de 1912 sobre os "sintomas transitórios", por exemplo, somos confrontados com um primeiro apontamento da importância da análise do analista, ideia que veio a ser formulada como uma segunda regra fundamental mais tarde no texto "A técnica psicanalítica" (1918). A uma segunda etapa Avello 
(1998) dá o nome de "etapa das inovações". Indo de 1918 até o final de sua vida, esta englobaria os tempos da técnica ativa (1918-1926), da elasticidade da técnica (1926-1928) e do relaxamento e da neocatarse (1929-1932) ${ }^{38}$ e, segundo o autor, revolucionaria a concepção das noções de trauma, contratransferência e regressão. É por conta desses dois últimos conceitos que dedicaremos especial atenção a este percurso inovador de Ferenczi no campo do manejo clínico.

Como vimos, em Freud a noção de contratransferência é pouco abordada e, quando o é, é em tom de alerta. Segundo Avello: "Revisando o núcleo de seu desenvolvimento, temos a sensação de que sua inclusão do conceito foi apenas uma forma de exorcizá-lo. Se a nomeia, é para dizer que o analista não deve sentila e então encerra o problema.” (Avello, 1998, p.87). Isso por si só expõe o caráter inventivo de Ferenczi que, mesmo enquanto fiel discípulo de Freud, deu grande importância ao conceito.

Mas a questão repousa menos na relevância da ideia de contratransferência em si e mais no fato de que o autor húngaro foi o primeiro a se preocupar com os afetos do analista durante a sessão. Desde seus primeiros trabalhos, ainda pensando sobre a hipnose na origem do método psicanalítico, Ferenczi se preocupava mais com a relação entre hipnotizado e hipnotizador do que com o funcionamento psíquico do hipnotizado como objeto isolado. É a partir desta compreensão que ele constrói pela primeira vez um raciocínio que será medular mais tarde em sua obra: a semelhança dos afetos despertados pelo hipnotizador com aqueles despertados pelos pais na relação com as crianças ${ }^{39}$. A hipótese apresentada ainda em 1909 de que, "No mais profundo do nosso ser continuamos crianças" (Ferenczi, 1909/2011, p.111), será mantida como chave em todo seu desenvolvimento teórico - em especial aquele que diz respeito a experiência que será entendida traumática.

\footnotetext{
${ }^{38}$ Em seu livro Avello (1998) inclui ainda uma última etapa, a da "análise mútua". Esta não tem, porém, um período bem delimitado, visto que é abordada apenas no "Diário clínico". Essa experimentação técnica não será abordada no presente trabalho.

39 Ferenczi fala inclusive em dois possíveis métodos de hipnose: uma hipnose paterna e outra materna. A primeira teria como característica o êxito pela intimidação, enquanto a segunda triunfaria em função do despertar de uma ternura. Nas palavras de Ferenczi: “A primeira condição de êxito de uma hipnose é que o médium encontre no hipnotizador um mestre, ou seja, que o hipnotizador saiba despertar nele os mesmos afetos de amor ou de temor, a mesma fé cega em sua infalibilidadeade que a criança sentia por seus pais". (Ferenczi, 1909/2011, p.111)
} 
Já em seu artigo de 1918 sobre "A técnica psicanalítica", ele adapta a analogia do hipnotizador/hipnotizado para a dupla analista/analisando. Ele diz perceber nos neuróticos uma tentativa de serem tratados como as crianças que em parte ainda são, cabendo ao analista resistir aos seus próprios impulsos contratransferenciais de simpatia ou autoritarismo excessivos. Nesse sentido, a contratransferência deve ser, não evitada ou negada como pensava Freud, mas "dominada". Ele diz:

sendo o médico, não obstante, um ser humano, e, como tal, suscetível de humores, simpatias, antipatias e também de ímpetos pulsionais - sem tal sensibilidade não poderia mesmo compreender as lutas psíquicas do paciente -, é obrigado, ao longo da análise, a realizar uma dupla tarefa: deve, por um lado, observar o paciente, examinar suas falas, construir seu inconsciente a partir de suas proposições e de seu comportamento; por outro lado, deve controlar constantemente sua própria atitude a respeito do paciente e, se necessário, retificá-la, ou seja, dominar a contratransferência ${ }^{40}$. (Ferenczi, 1918b/2011, p. 417)

Ainda nesse mesmo artigo, Ferenczi apresenta uma metáfora para o trabalho do analista que pode ser útil para introduzirmos a formulação da controversa técnica ativa. Ele lembra que durante um trabalho de parto normal, o ideal é que tudo ocorra naturalmente, permitindo ao obstetra uma posição mais passiva. Entretanto, ele deve estar a postos já que, no caso de uma não continuidade natural, caberia a ele uma intervenção que permita "um nascimento que não progride espontaneamente". (Ferenczi, 1918b/2011, p.412). De modo semelhante, o analista também deveria ser passivo até que não se possa mais sêlo. Há de se pensar nas possibilidades de uma intervenção de caráter mais ativo quando o processo de análise deixa de ocorrer "naturalmente", ou seja, quando a regra fundamental da associação livre deixa de ser suficiente mas o paciente segue assíduo.

É no texto sobre as "Dificuldades técnicas de uma análise de histeria" que Ferenczi (1919/2011) introduz a técnica ativa, a partir do caso de uma paciente histérica que, embora seguisse em seu processo analítico, já não apresentava progresso há um tempo. Às voltas com a técnica clássica, que à esta altura se mostrava insuficiente, Ferenczi percebe uma posição específica adotada pela

40 Grifo do original 
paciente durante as sessões e, entendendo que aquela era uma forma de onanismo "larvado", a proíbe. Ele diz: "Expliquei-lhe que essa era uma forma larvada de masturbação, a qual permitia descarregar subrepticiamente moções inconscientes e só deixar passar fragmentos inutilizáveis no material associativo". (Ferenczi, 1919/2011, p.1) O efeito dessa proibição foi “fulminante", a paciente logo volta a associar. Porém, o tratamento não tarda a, mais uma vez, estagnar.

A partir desta percepção, se desenha uma comparação entre o funcionamento em questão e aquele de um sistema hidráulico: na medida em que um ponto de escoamento é bloqueado, há de se buscar um novo. Esse deslocamento dos sintomas transitórios seriam meios de descarga que evitariam aquela desejada pelo trabalho analítico, que torna o material inconsciente consciente através da associação livre. Surge, então, uma nova tarefa do analista: além do material oferecido pela fala do analisando, ele deve considerar seu corpo e seu funcionamento em busca de atividades passíveis de alívio da tensão libidinal. Caso se note alguma atividade "masturbatória" - inconsciente e disfarçada - deve-se agir sobre ela de forma ativa.

Neste caso, fui levado a abandonar o papel passivo que o psicanalista desempenha habitualmente no tratamento, quando se limita a escuta e a interpretar associações do paciente, e ajudei a paciente a ultrapassar os pontos mortos do trabalho analítico intervindo ativamente em seus mecanismos (Ferenczi, 1919/2011, p.7)

Ferenczi segue o texto afirmando ser a técnica ativa uma nova forma de intervenção psicanalítica, a ser considerada um "método experimental". Este método se somaria aos já contemplados da observação e da dedução lógica (interpretação). Importante enfatizar ainda a distinção que ele nos oferece entre a técnica ativa e a sugestão: "Diferentemente da sugestão, não exercemos nenhuma influência sobre a nova direção do fluxo de energia e deixamo-nos surpreender de bom grado pelos rumos inesperados que, por esse fato, a análise venha a adotar" (Ferenczi, 1919/2011, p.7/8). É essa diferença que nos permite compreender o sentido "experimental” desta nova técnica. Ela não é um fim em si mas um meio de reativar o processo analítico estagnado sem, contudo, saber os caminhos que daí surgirão. Não devemos, portanto, compreender a 
experimentação como uma irresponsabilidade, mas sim como uma posição do analista que pretende mais abrir e movimentar o tratamento do que direcionar de forma objetiva um caminho pré-determinado.

Em um segundo artigo publicado sobre o tema, "Prolongamentos da 'técnica ativa' em psicanálise” (Ferenczi, 1920/2011), o autor nos oferece recomendações de uso desta nova técnica. Destacamos algumas: 1- ela de forma alguma substitui a técnica da associação livre, pelo o contrário, é um artifício auxiliar que pretende colocar os pacientes em melhor condição de obedecê-la; 2só deve ser adotada como último recurso; 3- uma vez utilizada deve ser abandonada assim que a estagnação for superada; 4- não deve ser considerada no início de um tratamento; 5- exige uma transferência já sólida e, por fim; 5- não deve ser utilizada por analistas iniciantes. Mais uma vez, a técnica ativa não deve ser compreendida como uma experimentação qualquer, e nem como uma atualização do fazer psicanalítico, mas como um recurso especial que sempre existira mas só tardou a ser nomeado.

Revisitando o método catártico de Breuer e Freud e a associação livre, Ferenczi (1920/2011) afirma que a atividade do analista sempre esteve presente na técnica psicanalítica mas antes agia apenas sobre a atividade psíquica do paciente e agora passa a atuar também sobre seu corpo e suas ações. Ele entende que as interpretações já eram comunicações ativas que, de alguma forma, orientavam o pensamento do analisando. A técnica ativa, por sua vez, expressa sua atividade através de injunções - "realizar certas ações desagradáveis" - e proibições "renunciar a certas ações agradáveis". Seu objetivo, porém, não é o acesso direto às memórias recalcadas, como no método catártico e hipnótico, mas sim uma redistribuição libidinal.

Caberia ainda pensar como os sintomas transitórios, que se manifestam sobretudo em uma esfera corpórea e, por definição, apenas contidos no setting analítico, poderiam ser compreendidos como momentos regressivos. Embora a esta altura a compreensão ferencziana ainda se apoiasse sobretudo numa linguagem pulsional, veremos como a partir da experimentação da técnica ativa abriu-se um caminho para pensar as atitudes de pacientes como as descritas no 
texto de 1919 como manifestação de estados mais primitivos na presença segura do analista. Ou seja, como vivências regressivas em análise.

Não podemos deixar de notar que a técnica ativa descrita por Ferenczi tem como base o princípio que Freud chamou de "abstinência" e que ela dialoga com a ideia de "frustração". Ambas as noções freudianas defendem que a recusa do analista a satisfazer o paciente é essencial para manter o desejo de cura como guia do tratamento. Nesse sentido, a não intervenção em momentos de estagnação do tratamento colocaria o analista em um lugar de cúmplice da resistência do paciente.

Há um dado importante que ainda deve ser mencionado sobre o uso da técnica ativa e o período no qual ela surge. Como pode-se observar de forma bastante explícita no texto de Ferenczi em conjunto com Otto Rank, "Perspectivas da psicanálise" (1924b/2011), bem como no famoso artigo de Freud sobre o “Além do princípio do prazer" (1920/2010), nesse período começa a ser valorizado um processo psíquico do paciente em análise que é, não a rememoração, mas a repetição. Esse deslocamento pode ser acompanhado desde cedo na história da psicanálise. Nos artigos técnicos "A dinâmica da transferência" (Freud, 1912a/2010) e "Recordar, repetir e elaborar" (Freud, 1914b/ 2010), Freud já apontava este tipo de manifestação do material inconsciente que se daria, não necessariamente pela fala, mas pelas ações e pelo relacionar-se do paciente. O que começa a ser colocado como questão é a repetição da forma de lidar com os objetos do mundo e, portanto, com o prazer e o desprazer.

Essa valorização da repetição ocorre a partir da compreensão de que certas experiências não puderam ser inscritas no plano da representação e, portanto, não funcionariam como traços mnêmicos a serem rememorados. Na impossibilidade de serem lembrados, só podem aparecer na relação se repetindo em ação aqui e agora - certas expressões só podem ganhar corpo em uma experiência atual (Ferenczi, 1924b/2011, p.253).

Essa ideia será essencial ao explorarmos a regressão como efeito da qualidade do vínculo entre paciente e analista e, portanto, fenômeno que não pode deixar de incluir o analista enquanto sujeito. Na medida em que temos um analista 
mais implicado na relação clínica, atuando como representante no presente dos investimentos afetivos do paciente, começa a se perceber que certas expressões só podem aparecer pela experiência atual.

Esse mesmo inconsciente, cuja descoberta constitui a tarefa principal da psicanálise, não pode - uma vez que nunca foi "sentido" - ser, "rememorado", e certos sinais obrigam a deixá-lo reproduzir-se. A simples comunicação, por exemplo uma "reconstrução", não é capaz por si só de produzir reações afetivas; ela permanece inicialmente sem nenhum efeito sobre os pacientes. É preciso esperar que eles vivam atualmente algo análogo na situação analítica, ou seja, no presente, para que cheguem a convencer-se da realidade do inconsciente, e mesmo assim será necessário que ocorram várias experiências desse gênero. (Ferenczi, 1924b, p.253)

Essa novidade da ênfase no presente servirá de base para o desenvolvimento da controversa ideia da regressão enquanto ferramenta terapêutica. Na medida em que se valoriza a repetição daquilo que não pode ser rememorado, não só falamos da importância da relação analista-analisando mas também colocamos em maior estima as expressões que, na medida em que não foram inscritas, aparecem em formas mais primitivas do que as representações verbais. Entendemos que, ao falar da técnica ativa e dessas tentativas de compreensão da experiência anterior à verbal, Ferenczi já anunciava a regressão enquanto assunto central da técnica analítica. À essa altura, não podemos deixar de lembrar do que Freud chamou de regressão formal ao descrever os processos oníricos. Medeiros (2020), ao pensar a clínica do trauma, nos lembra que, embora Freud reconhecesse esses movimentos, hesitava em trabalhá-los por outros meios que não a interpretação. Talvez possamos entender, portanto, que a diferença entre Freud e Ferenczi no que diz respeito a regressão reside mais na forma como a manejam do que em seu reconhecimento.

Uma vez notada a importância da repetição, no seu artigo sobre "As fantasias provocadas" (Ferenczi, 1924a/2011) o autor fala de ainda outra forma de intervenção dita ativa. Às proibições e injunções ordenadas sobre o corpo soma-se uma intervenção dirigida ao material associativo. $\mathrm{O}$ que o autor vem a sugerir é que certos pacientes padecem de uma "pobreza da vida de fantasia" e podem se beneficiar de uma provocação por parte do analista que funcionaria como forma de investigar a "vida fantasística inconsciente" (Ferenczi, 1924a/2011, p.268) 
Ciente das críticas que pode e de fato vem a sofrer, Ferenczi aponta como também nas tradicionais interpretações já se pode notar um nível de atividade. Ele diz:

Quando interpretamos as associações livres do paciente, o que fazemos inúmeras vezes durante uma sessão, desviamos o curso de suas associações, suscitamos nele representações de expectativa e abrimos assim caminho para seus encadeamentos de ideias, mesmo ao nível do conteúdo; somos, portanto, extremamente ativos, pois isso equivale a formular interdições de associar. (Ferenczi, 1924a, p.262)

Nesse sentido, a técnica ativa não diverge tanto do método tradicional. Em ambos podemos encontrar uma atividade do analista que inevitavelmente atua sobre o processo psíquico do paciente. Talvez a distinção mais importante a ser feita seja entre as técnicas ativa e a interpretativa e o método sugestivo, já que este, por sua vez, se utiliza da transferência e da atividade para chegar a um fim específico enquanto aquelas pretendem abrir o caminho, mas não percorrê-lo.

Ainda no mesmo artigo, Ferenczi descreve essas fantasias provocadas como formas de investigar a "vida fantasística inconsciente" (Ferenczi, 1924a/2011, p. 268). O analista propõe um tema ou situação e pede ao analisando que narre "todas as ideias que lhe acodem ao espírito sem levar em conta sua realidade objetiva" (Ferenczi, 1924a/2011, p.263). Ferenczi pôde notar, a partir da qualidade das fantasias dos pacientes, que as crianças "excessivamente bemeducadas" (Ferenczi, 1924a/2011, p.268) tinham sua liberdade de fantasiar tolhida, o que o leva a concluir que deve haver uma relação - que será contemplada em especial na sua teoria do trauma - entre as experiências sexuais infantis e a capacidade imaginativa. No caso da criança excessivamente bemeducada, a omissão da vida sexual levara a sua supressão. Por outro lado, uma criança que vivencia algo excessivo, precoce ou intenso demais, também parece ter suas fantasias "empobrecidas" (Ferenczi, 1924a/2011).

Se unirmos as conclusões obtidas a partir dessas reflexões, somos confrontados com uma conclusão inevitável. Os pacientes que estagnavam em análise, que deixavam de associar livremente mas seguiam assíduos ao tratamento, buscavam outra coisa que não esse tipo de descarga para se expressar. Ao que tudo indica, o que os mantinha ali seria menos o processo de cura pela fala e mais a própria presença do analista. $\mathrm{O}$ breve sucesso dessas injunções e 
proibições deixa transparecer que um estímulo à fala não é suficiente para alcançar bons resultados terapêuticos, já que não se trata de excesso de resistência mas de falta de representações. É preciso aprender a falar antes de se libertar para tal. É nesse sentido que, percebendo nela muito mais uma repetição do traumático do que um acolhimento necessário aos estados regressivos, Ferenczi logo renunciará à técnica ativa.

Quase uma década após a sua introdução, Ferenczi (1926/2011) publica as “Contraindicações da técnica ativa". Nelas, Ferenczi mostra que, embora essa técnica por vezes tenha se mostrado - e continue podendo ser - útil para o tratamento - mas apenas quando todos os outros recursos se esgotaram -, ela comporta três grandes problemas: 1- o aumento da resistência; 2- a perturbação da transferência e; 3- a reprodução da situação traumática. Para nós, o ponto mais importante é o terceiro, que aponta a percepção de que as imposições colocadas sobre os pacientes, seguidas sem qualquer questionamento, repetem uma posição de submissão e sofrimento. Ele se percebe, enquanto analista, reproduzindo de alguma forma a agressividade presente na relação entre pais e filhos, ou seja, deixando de perceber a necessidade infantil de um acolhimento. Ao agir impositivamente com seus pacientes, Ferenczi estaria incidindo sobre eles com uma linguagem excessiva e traumática.

Não podemos deixar de apontar o marco que é para o desenvolvimento da psicanálise a inversão promovida por Ferenczi ao remeter a resistência à relação com o analista e com o ambiente analítico ao invés de atribui-la aos processos de defesa intrapsíquicos. A resistência opera aqui como uma defesa do ego perante o analista, e não contra desejos inconscientes. Não é o material recalcado que é insustentável mas a revisitação da experiência do trauma.

Diante deste cenário, Ferenczi afirma que as "instruções ativas" (Ferenczi, 1926/2011, p.404) por parte do analista devem ser, não “de uma intransigência estreita mas de uma flexibilidade elástica" (Ferenczi, 1926/2011, p.404). Isto não quer dizer, entretanto, que o analista deva atender todos os desejos do analisando e tratá-lo de forma excessivamente amigável, e sim viabilizar um ambiente favorável no qual seja possível revisitar as experiências traumáticas da infância de 
forma segura. Nas palavras de Ferenczi, a situação terapêutica "deve repetir as reações do paciente à privação em condições mais favoráveis do que aquelas que foram possíveis na infância e corrigir os distúrbios do desenvolvimento cuja reconstituição histórica possa ser feita” (Ferenczi, 1926/2011, p.408). Aqui novamente encontramos, agora de forma explicita, a gênese de um entendimento das regressões em análise enquanto vivência de potencial terapêutico.

\section{4}

\section{A elasticidade como princípio técnico}

No último texto sobre a técnica ativa, Ferenczi (1926/2011) introduz duas noções que serão de suma importância em sua obra: flexibilidade e laisser-faire. Em suas explorações da atividade do analista, ele percebe que talvez não a intransigência, mas a flexibilidade, pode "favorecer a descoberta de moções infantis recalcadas" (Ferenczi, 1926/2011, p.407). Ele narra situações nas quais, diante de uma maior liberdade dentro do setting, os pacientes se permitem expressar coisas que nunca apareceram no contexto da associação livre, ou seja, se permitem regredir e dar corpo a outras formas de expressão que não podiam ser acolhidas pela técnica clássica. A ideia da regra fundamental, já contendo nela a palavra "livre", está evidentemente de acordo com a noção de rebaixamento de julgamentos morais dentro da relação terapêutica, mas o que Ferenczi faz é, mais uma vez, ampliar essa ideia. A exploração dos efeitos da atividade do analista sai do foco de suas experimentações para dar vez à atividade espontânea do paciente.

Ferenczi inicia "Elasticidade da técnica psicanalítica" (1927/2011) postulando o que ele considerou ser a segunda regra fundamental da psicanálise. Ele diz: "quem quer analisar os outros deve, em primeiro lugar, ser ele próprio analisado41" (Ferenczi, 1927, p31). Esta novidade conceitua, enfim, o que já vinha se desenhando em sua clínica desde os primórdios ${ }^{42}$, o lugar de relevância do psiquismo do analista na dupla analista-analisando. Se nos esforçamos um

\footnotetext{
${ }^{41}$ Grifo do original

42 Segundo Borgogno (1998), já em sua primeira publicação psicanalítica podemos perceber seu olhar relacional ao pensar nos efeitos sobre a mulher da ejaculação precoce do parceiro.
} 
pouco, logo o acompanhamos. A associação livre, primeira regra colocada por Freud, tem de início o seguinte objetivo: que o paciente rebaixe sua censura, à maneira dos sonhos, para que o material recalcado possa ter seu acesso à consciência facilitado. Em um segundo momento da obra freudiana, a regra fundamental serve, ainda, como tentativa de não ceder à resistência que se impõe ao tratamento. Trabalha-se, portanto, sempre com o objetivo de "libertar" as representações inconscientes. O que Ferenczi vem a perceber, entretanto, é que esse trabalho não pode ser compreendido como algo estritamente intrapsíquico, pois ele depende da confiança no analista.Tomemos a seguinte citação:

a relação do doente com o médico como pivô do material analítico, e conceber de imediato cada sonho, cada gesto, cada ato falho, toda deteriorização ou melhoria do estado do paciente como outras tantas expressões da relação transferencial e da resistência" (Ferenczi, 1926, p. 408).

Fica evidente a grandeza da inversão proposta: as manifestações do inconsciente deixam de ser vistas apenas como "retorno do recalcado" e são expostas como acontecimentos de uma relação. O jogo de forças não é só intrapsíquico mas também intersubjetivo.

A partir de 1926 entramos então em um segundo momento do que Avello (1998) chamou de "etapa das inovações técnicas". Deixamos de lado a técnica ativa e falamos da "técnica elástica" (1926-28) e, depois, do relaxamento e da neocatarse (1929-1932). Ambas serão focais em nosso trabalho na medida em que jogam luz sobre a relevância do jogo transferência/contratransferência e permitem um manejo de estados regressivos em análise. Recorremos a Borgogno (1998/2004) para definir elasticidade, de onde partiremos:

Para Ferenczi, elasticidade não quer dizer absolutamente, como muitos ainda afirmam, indulgência e simetria, mas início de reconhecimento e elaboração da própria influência e das próprias funções no processo psicanalítico, inclusive limites. É, portanto, um aumento da responsabilidade ${ }^{43}$ do analista no tratamento diário do paciente e uma maior consciência da subjetividade de sua participação em qualquer sessão e durante um longo período de análise. (Borgogno, 1998, p. 150)

${ }^{43}$ Grifo do original 
Essa introdução da responsabilidade do analista é algo profundamente explorado por Ferenczi (1927/2011) em seu primeiro texto sobre a elasticidade. Nele, encontramos a descrição de um analista que, longe de estar ali como espelho, é alguém dotado de uma presença sensível e de uma consciência dos efeitos de suas atitudes sobre o paciente. O autor diz ter desenvolvido "a convicção de que se trata, antes de tudo, de uma questão de tato psicológico" (Ferenczi, 1927/2011, p.31).

O conceito de tato, embora criticado por muitos, é central para se compreender a posição ocupada pelo analista na teoria ferencziana. Essa faculdade deve ser pensada como a habilidade de "sentir com" (Einfülhung) e, pelo vínculo transferencial, intuir como e quando uma comunicação deve ser feita ao paciente. Não se trata, portanto, de desvelar juntamente ao paciente seus conteúdos inconscientes. Mesmo quando estes parecem explicitados, é preciso antes o estabelecimento de uma relação de confiança. É apenas a partir de tal que o paciente poderá atuar na relação com o analista suas moções inconscientes. Remetendo-nos à já ultrapassada técnica ativa, destaca-se agora a importância de ser, não o analista, mas o paciente quem, a partir da segurança provida pelo setting, manifesta uma atividade.

Se somamos esta ideia ao que Ferenczi trouxe como a segunda regra fundamental, podemos perceber que o deslocamento vai no sentido de responsabilizar, não o paciente, mas o analista e a técnica pelos impasses clínicos enfrentados. Se colocamos os desafios do tratamento apenas na conta da resistência e dos entraves psíquicos do paciente, reproduzimos a atitude hipócrita dos adultos de cobrar das crianças algo pelo qual não podem ainda se responsabilizar. Ou seja, o analista que deixa de considerar seu papel na relação da análise pode, sem perceber, reproduzir a posição do agressor que age de maneira excessivamente intensa.

Quando Ferenczi (1927/2011) fala em uma metapsicologia do analista ele está apontando, portanto, a importância de dominar os impulsos de forma a não se deixar levar pelo próprio narcisismo. Ao pensar na criança que foi um "hóspede 
não bem-vindo na família4" (Ferenczi, 1929, p.57), ou seja, ao colocar em destaque a importância do ambiente na vida infantil, Ferenczi entende que o que certos pacientes precisam no tratamento analítico é, em primeiro lugar, de uma possibilidade de criar e dar sentido à própria existência. Portanto, "deve-se deixar, durante algum tempo, o paciente agir como uma criança" - o que nos remete, mais uma vez, à ideia já apresentada de que, para Ferenczi, estamos sempre lidando com a criança dentro do adulto. Em "O problema do fim da análise” (1927/2011), ele diz:

Parece-me muito provável que os pacientes procurem repetir, por essas tentativas, situações de sua infância em que educadores e pais incompreensivos reagiram às chamadas "maldades" da criança por meio de manifestações afetivas intensas, levando assim a criança a adotar uma atitude de recusa. (Ferenczi, 1927/2011, p. 24)

Ou seja, a partir do encontro com uma gama de pacientes que não respondiam à técnica clássica, que não avançavam com destreza apenas pela díade da associação livre e da escuta/atenção flutuante, Ferenczi percebe haver no encontro entre paciente e analista uma experiência que antecede àquela da frustração e da abstinência defendida por Freud e explorada na técnica ativa. A preocupação deixa de ser apenas a de abrir caminho para a expressão de materiais inconscientes e passa a ser antes a de viabilizar um espaço de criação do $\mathrm{Eu}$, de possibilitar uma experiência de afirmação de si. Como vimos antes ao falar dos tiques e das neuroses de guerra, certos casos parecem exigir uma "análise de caráter" além de uma "análise de sintoma". Nesses casos, Ferenczi prioriza, portanto, o estado que chamou de laisser-faire. Tomemos uma citação do texto de 1929 mencionado acima:

De acordo com as minhas tentativas de elasticidade da técnica analítica, relatadas em outro artigo, nesses casos de diminuição do prazer de viver, vi-me pouco a pouco na obrigação de reduzir cada vez mais as exigências quanto à capacidade de trabalho dos pacientes. [...] Por esse laisser-faire ${ }^{45}$ permite-se a tais pacientes desfrutar pela primeira vez a irresponsabilidade da infância, o que equivale a introduzir impulsos positivos de vida e razões para se continuar existindo. Somente mais tarde é que se pode abordar, com prudência, essas exigências de frustração, que, por outro lado, caracterizam as nossas análises. (Ferenczi, 1929/2011, p.59/60)

\footnotetext{
${ }^{44}$ Grifo do original

${ }^{45}$ Grifo do original
} 
Esta ideia de que na análise certos pacientes enfim experienciariam "a irresponsabilidade da infância" expõe um novo tipo de trabalho analítico. A frustração fica em segundo plano e a ideia de repetição ganha uma nova conotação. Balint, aluno de Ferenczi, trabalhará mais afundo esta ideia mas já aqui podemos perceber com clareza a compreensão de que, para alguns pacientes, o tratamento freudiano, que sucede nos casos de neurose, é um de complexidade excessiva para outros pacientes. Para se trabalhar no nível da neurose, ou seja, no campo dos conflitos inconscientes operados pelo recalque, é preciso antes atentarse a outro tipo de sintoma que se manifesta não pelo conflito mas pela falha. Nesses pacientes a demanda apresentada seria a de uma atmosfera permissiva, que oferece segurança para o desenvolvimento de novos recursos. É o que, a partir das descobertas de Ferenczi, passamos a chamar de regressão terapêutica.

Não à toa, começamos o capítulo falando sobre o desenvolvimento do Ego para Ferenczi. As "lesões do Ego", explicadas até aqui apenas de maneira breve, fazem referência a sintomas de caráter narcísico, e não sexual. Em "A elasticidade da técnica como projeto e percurso psicanalítico" (1998/2004), Borgogno fala como o que encontramos na obra de Ferenczi é uma ampliação do próprio inconsciente freudiano. Passa a se trabalhar clinicamente também com experiências que foram sequer inscritas psiquicamente. A partir das mesmas, torna-se imprescindível que o analista se volte para o corpo do paciente e para os afetos vividos na relação. São nessas outras dimensões, que superam a ideia de representação, que se manifestam os sofrimentos e as particularidades do caráter nas relações com os objetos.

Seguiremos explorando essa clínica ferencziana no próximo item, onde dedicaremos maior atenção à traumatogênese e à ideia de regressão enquanto ferramenta clínica. Mas antes disso, ingressemos em um último momento do desenvolvimento técnico de Ferenczi no qual falaremos do princípio de relaxamento, iniciado pela percepção do valor de um técnica mais elástica, e da ideia de neocatarse. 
Para dar início ao que Avello (1998) considerou a penúltima etapa da técnica de Ferenczi extraímos duas citações de seu texto sobre o "Princípio de relaxamento e neocatarse" (1930/2011):

No decorrer de minha longa prática analítica, vi-me constantemente na situação de transgredir ora um ora outro dos 'conselhos técnicos' de Freud. A fidelidade ao princípio segundo o qual o paciente deve estar deitado no divã foi ocasionalmente traída pelo ímpeto incontrolável do paciente para levantar-se de um salto, ficar deambulando pelo gabinete ou falar comigo de olhos nos olhos. (Ferenczi, 1930/2011), p.67) ${ }^{46}$

E: "Entretanto, a acumulação de casos de exceção leva-me a formular um princípio até então não postulado, embora tacitamente admitido, o princípio de laisser-faire que cumpre admitir, com frequência, a par do princípio de frustração" (Ferenczi, 1930/2011, p.68)

No momento final de sua trajetória, no qual se afirma o princípio do relaxamento e a ideia de neocatarse, podemos perceber uma espécie de compilação de suas contribuições técnicas. Partindo da ideia de laisser-faire introduzida através da problematização da técnica ativa, Ferenczi (1930/2011) coloca o relaxamento não como possibilidade ou inovação técnica mas como um polo que sempre estivera presente e que agora recebe o devido destaque. Trata-se, segundo ele, de uma oposição fundante no trabalho psicanalítico: "um aumento de tensão pela frustração e um relaxamento ao autorizar certas liberdades" (Ferenczi, 1930/2011, p.68).

Ferenczi (1930/2011) nos lembra como os dois movimentos já se apresentavam mesmo nos primórdios, na regra fundamental. Ora, por um lado temos uma pressão imposta ao paciente que deve "confessar verdades desagradáveis" (Ferenczi, 1930/2011, p.68) e, por outro, a permissão, mesmo o convite, a libertar-se pela fala. O problema proposto é: o falar livremente, embora passível de relaxamento em seu efeito, exige um alto nível de tensão para exercer sua função catalisadora. Ambos, relaxamento e frustração são, portanto, dois polos de uma técnica bilateral.

A proposta, portanto, vai no sentido de afirmar que, quando percebido na relação, pelo tato do analista, o relaxamento pode contribuir para o andamento do

${ }^{46}$ Grifo do original 
tratamento. Não é suficiente que o paciente possa falar livremente, cabe ao analista poder acolher seus movimentos, seu devir, de forma mais plena. Isso, é claro, sempre baseado em prudência (Ferenczi, 1929/2011) e sinceridade (Ferenczi, 1930/2011). A possibilidade de atender de graça, o prolongamento das sessões, a realização de mais de uma sessão por dia são alguns dos exemplos usados pelo autor que nos ajudam a pensar o manejo de pacientes em estados regredidos.

Embora venhamos falando da atuação conjunta da frustração e do relaxamento, veremos como, em alguns casos específicos, torna-se importante que o princípio do relaxamento seja priorizado.

Ao comparar a atitude inicialmente obstinada e fixa do paciente com a flexibilidade que resultava do relaxamento, pode-se constatar nesses casos que o paciente vê a reserva severa e fria do analista como a continuação da luta infantil contra a autoridade dos adultos, e que repete agora as reações características que estiveram na base de sua neurose propriemente dita. (Ferenczi, 1930/2011, p.70)

Ou seja, embora de valor evidente, a postura do analista que obedece a um princípio de frustração pode vir a repetir uma situação outrora traumática. Assim sendo, Ferenczi (1930/2011) acredita que, quando a mesma é adotada de forma excessivamente intensa ou fixa, esta geraria ao paciente mais sofrimento do que a quantia necessária para viabilizar o tratamento. Deste questionamento surge a noção de "economia de sofrimento": "Eu escolheria a expressão 'economia de sofrimento' para fazer compreender e ensinar, sem equívocos demais, assim espero, como trabalhar com o princípio de frustração e com o princípio de laisserfaire" (Ferenczi, 1930/2011, p.71)

Ferenczi (1930/2011) fala ainda em um efeito curioso da clínica baseada no relaxamento. Ele percebe em alguns de seus pacientes que, “após ter-se conseguido criar uma atmosfera de confiança um pouco mais sólida entre médico e paciente, assim como o sentimento de uma maior liberdade" (Ferenczi, 1930/2011, p. 71), sintomas corporais e lembranças recalcadas afloram de maneira ainda mais viva e aderente do que na clínica da abstinência. O autor chega a mencionar um estado de transe que o paciente parece alcançar, à maneira das 
primeiras histéricas atendidas por Breuer e Freud no final do século XVIII. Ele chamará esse estado de neocatarse.

Até aqui vimos, portanto, como, na medida em que se atribui importância ao agir e ao sentir do analista na obra de Ferenczi, vem à luz a importância da qualidade da relação com o paciente para o tratamento. Encontrando na postura do analista um possível adulto tirano que pode repetir a falta de tato traumática de pais e educadores, Ferenczi já anuncia que, em sua teoria, o trauma será percebido como um acontecimento exógeno e que, portanto, também o analista é passível de provocar tal efeito. A resistência, o traumático e a transferência, não são apenas consequências de desvios e problemas quantitativos da pulsão, são, em si, dependentes da alteridade. Esses fenômenos não dizem respeito apenas à transferência, mas também à contratransferência. Não implicam só em frustração, mas também em relaxamento. Aí estão em jogo não apenas pulsões de vida e de morte, mas também o Eu e o ambiente. Em última instância, portanto, um trabalho clínico que prioriza o trauma e a regressão convoca um olhar necessariamente relacional.

\section{5}

\section{Clivagem enquanto defesa, regressão enquanto manejo}

Todo este percurso pela obra de Ferenczi nos leva a um fechamento que inclui, por um lado a noção de trauma desestruturante e a clivagem enquanto defesa psíquica análoga ao recalque e, por outro lado, no que diz respeito a técnica, a regressão enquanto possibilidade de uma repetição elaborativa decorrente de uma relação de tato do analista para com o paciente. Em um primeiro momento apresentamos a teoria filogenética de Ferenczi; Thalassa expõe, em complexas vias paralelas entre o desenvolvimento do sujeito e do meio, as as travessias de um percurso marcado por catástrofes e traumas.. Vimos como as rupturas, embora e, porque disruptivas, são as responsáveis pelo movimento, pelas criações e pelo surgimento da vida. Ao pensar a história do sujeito trabalhamos também com a ideia de traumas necessários, estruturantes, mas isso 
não garante a ausência daqueles que são, em seu potencial disruptivo, desestruturantes e aniquiladores.

No prefácio do quarto e último livro das obras completas de Ferenczi, Balint nos fala sobre os pacientes atendidos por seu mestre: “[...] se pode constatar que os pacientes que Ferenczi analisa estão, com frequência, nos limites da dissociação e da paranoia, muito mais doentes do que as clássicas 'boas indicações' para tratamento, e de quem ele não receava ocupar-se” (Balint, 2011, p.VIII). Por muito tempo Ferenczi foi conhecido apenas por isso, o enfant terrible da psicanálise que desafiava a técnica clássica com seus pacientes distintos. Porém, na medida em que seu trabalho vai ganhando importância - tardiamente dentre psicanalistas, suas elaborações teóricas vão sendo devidamente reconhecidas. Neste prefácio Balint lista algumas delas: a criança em relação ao acolhimento, a ideia de confusão de línguas, a clivagem enquanto defesa, a função traumatolítica do sonho e a transferência materna. Para fechar este capítulo as abordaremos entendendo que, de uma maneira ou outra, se compõem em sua teoria do trauma.

Segundo Borgogno (1997/2004), podemos entender como trauma para Ferenczi aquilo que, de forma repentina ou cumulativa, age sobre o sujeito de forma excessiva - seja por exagero ou privação - impedindo a elaboração da experiência vivida e, segundo Pinheiro (2003), rompendo com a certeza de si e com a faculdade de autorrepresentação. Diante desse(s) evento(s) arrebatador(es), a criança precisa recorrer a uma defesa psíquica drástica. Borgogno diz:

O seu efeito é por ele reconhecido na patologia borderline e psicótica, onde o ego sofreu uma consistente humilhação a nível do amor-próprio, e a cisão e a o dissociação, com consequente alteração da consciência, tomam o lugar do recalque e dos mecanismos mais especificamente neuróticos como resposta de sobrevivência e de defesa psíquica. (Borgogno, 1997/2004, p.169)

Em Ferenczi, vemos esse raciocínio se desenhar a partir da ideia da criança mal acolhida, trazida no texto de 1929. O autor percebe que, nos adultos nos quais aflora uma "vontade de morrer", houve um sentimento na infância de não ser desejado que acarretou um desenvolvimento falho no que diz respeito a construção egóica. Ferenczi diz sobre um desses casos de crianças mal acolhidas: 
"Neste caso, como em todos os outros, o conflito edipiano constituía, naturalmente, uma prova de força; ela não estava à altura para enfrentálo" (Ferenczi, 1929/2011, p. 57). Logo, não se trata de uma questão neurótica, da ordem do conflito, mas de uma falha narcísica. Nesses casos, o que o psicanalista pode oferecer não é uma interpretação mas um acolhimento e uma permissão para ser - "deve-se deixar, durante algum tempo, o paciente agir como uma criança" (Ferenczi, 1929/2011, p.59).

Assim, é o princípio de relaxamento que torna possível para esses pacientes que não puderam desfrutar da ternura da infância de forma suficiente, desenvolverem sua "vontade de viver". Para Ferenczi, ainda que se possa pensar em uma pulsão de morte, esta não fala de um problema estritamente pulsional, mas de um excesso proveniente do ambiente vivido na infância. A tarefa da terapia analítica não seria então a de ligar representações, construir significados, mas a de construir um eu, de integrar suas partes apartadas pela violência do trauma. Nas palavras de Ferenczi:

Para essas pessoas que, mesmo na realidade, mantiveram-se quase inteiramente infantis, não seriam suficientes os auxiliares habituais do tratamento analítico. Do que esses neuróticos precisam é de ser verdadeiramente adotados e de que se os deixe pela primeira vez saborear as bem-aventuranças de uma infância normal. ${ }^{47}$ (Ferenczi, 1929/2011, p.77)

Essa noção, recorrente em sua obra, de que o analista deve lidar com a criança no paciente, chega ao ápice de seu desenvolvimento no importante texto de 1931, “Análise de crianças com adultos". Nele, Ferenczi fala de seus pacientes difíceis e sobre como foi possível lidar com eles a partir do manejo da regressão, ou seja, a partir de um tato com as crianças paralisadas vivas naqueles adultos.

Ao longo de toda sua obra nos deparamos com passagens que enfatizam a importância da qualidade dos primeiros cuidados. Diferente de Freud, que foca na distribuição pulsional para avaliar os fenômenos - os aumentos de tensão e as descargas energéticas como forma de compreensão da interação entre o Eu e os objetos -, Ferenczi coloca em destaque a qualidade da relação com esses objetos aos quais o eu se dirige. A partir da noção de introjeção, que já aqui apresentamos,

${ }^{47}$ Grifo do original 
ele entende que essas relações são constituintes. Na medida em que temos esse deslocamento teórico, muda a forma de entender a constituição subjetiva e, portanto, o papel do analista. Para explicitarmos esta diferença a fim de descrever o manejo da regressão, tomaremos os mitos que Freud e Ferenczi usaram para pensar situações fundantes da infância.

Em 1905, Freud revoluciona a ideia que se tem da infância ao descrever um desenvolvimento sexual que abrange vivências tão antigas quanto o ato de mamar. Nesse desenrolo, ele toma uma situação triangular para descrever as operações que atuam sobre o sujeito a fim de incluí-lo enquanto eu formado nas relação com a alteridade. É a partir do conflito entre bebê, pai e mãe, no qual a ambivalência e a identificação se colocam enquanto processos psíquicos, que a criança ingressa no mundo simbólico da sexualidade genital. A partir do que se chamou de complexo de Édipo - em alusão ao mito grego no qual encontramos as vivências do incesto e do parricídio -, o sujeito é inserido na moral e se organiza enquanto sujeito desejante e castrado. É a partir desta operação psíquica que Freud compreende as distribuições libidinais e as identificações que formam o sujeito.

Bem, em 1933, Ferenczi propõe uma nova história, também com três integrantes. Vejamos, o "mito" de Ferenczi de forma alguma anula o freudiano. Correndo o risco de repetir-nos, enfatizamos mais um vez que, as diferenças propostas por Ferenczi, não pretendem descreditar nem a técnica nem a teoria clássica, antes apontam para um outro aspecto da subjetividade, e nesse sentido são inovadoras. A questão que se coloca é uma já tratada no início do capítulo: enquanto Freud focou no desenvolvimento sexual, Ferenczi interessou-se, a partir dos casos que atendeu, pelos acometimentos no desenvolvimento do Eu.

Prosseguimos. A situação que Ferenczi (1933/2011) nos traz, de maneira resumida, é a de um adulto que se dirige à criança, em um momento de loucura, de forma passional, ou seja, excessiva. A criança, incapaz de compreender aquela expressão, se dirige a um segundo adulto, o terceiro integrante da história, em busca de esclarecimento sobre o ocorrido. Este, por sua vez, não dá importância ao ocorrido e o "desmente", ou seja, descredita a experiência vivida pela criança. Não havendo recursos psíquicos para se defender nem tampouco elaborar o 
ocorrido, a criança ansiosamente introjeta o agressor em uma tentativa de compreensão. Introjeta porque, psiquicamente, é o que ela sabe fazer mas, na medida em que o faz, se divide em dois Eus que se contradizem. Por um lado tem seu corpo, que registra o que foi vivido, que é marcado pela experiência, por outro o agressor introjetado, que nega. A criança tem seu desenvolvimento paralisado (Borgogno, 1997/2004), fica congelada no tempo e, pelo estado de confusão no qual se encontra, éconvertidaem um "serque obedece mecanicamente" (Ferenczi, 1933/2011, p.118).

Levar-nos ia muito longe falar aqui de todas as neuroses e das consequências que podem resultar do enxerto prematuro de formas de amor passional e recheado de sentimento de culpa num ser ainda imaturo e inocente. A consequência só pode ser essa confusão de línguas a que fiz alusão no título desta conferência. (Ferenczi, 1933/2011, p.118)

A mistura entre as capacidades da criança e as do adulto agressor introjetado, gera na criança um estado permanente de confusão mental entre o que viveu ou não, ou seja, uma confusão efetivamente narcísica, sobre a própria existência.

Fica evidente que, em Ferenczi, o trauma é "algo adicional e diferente que provém do externo" (Borgogno, 1997/2004, p.169). Não se trata de um desequilíbrio pulsional mas de uma disrupção na continuidade e constituição do ser enquanto um eu integrado. Diferentemente da neurose, na qual temos que o inconcebível é recalcado, no trauma ferencziano temos uma experiência que, enquanto vivida pelo corpo, não pôde ser simbolizada psiquicamente. A defesa atuante não é o recalque, que separa a vivência de seu afeto, mas a clivagem, que na impossibilidade de representar o vivido, rompe o eu entre um que viveu mas não sente que viveu e outro que sofre sem saber o porquê (Borgogno, 1997/2004, p.178). Ou seja, separam-se experiência e percepção, abalando a possibilidade do sujeito de crer em si mesmo, em seus próprios sentidos.

Importante acrescentar a essa vivência do desmentido ainda duas outras experiências que Ferenczi (1933/2011) usa para pensar a situação traumática: as medidas punitivas insuportáveis e o terrorismo de sofrimento. Todas as três situações falam de uma ameaça do ambiente que coloca a criança em um estado de constante alerta e docilidade preventiva. Para se defender desses extremos que 
lhes são impostos, ela responde, de forma patológica, através do que Ferenczi (1933/2011) chamou de “progressão traumática”. Ou seja, diante da situação traumática, a criança acelera seu desenvolvimento para além do que seria o normal para poder se defender. Para pensar tal desfecho, Ferenczi oferece uma analogia entre esse desenvolvimento forçado e um fruto maduro. Ele diz: "Pensase nos frutos que ficam maduros e saborosos depressa demais quando o bico de um pássaro os fere, e na maturidade apressada de um fruto bichado" (Ferenczi, 1933/2011, p.119). Ainda nesta linha, ele alude a um escrito mais antigo sobre o sonho do bebê sábio, o qual fala de um medo dos adultos "loucos" que transforma a criança em um adulto psiquiatra - "para proteger-se do perigo que representam os adultos sem controle, ela deve, em primeiro lugar, saber identificar-se por completo com eles" (Ferenczi, 1933/2011, p.120).

A partir disso questionamos: que tipo de tratamento pode beneficiar esse tipo de paciente não-neurótico? Qual a função do analista nesse tipo de caso? Não pode ser a de rememorar, o trauma não foi "esquecido", recalcado, mas antes sequer representado. Trata-se, portanto, de oferecer a permissão e a possibilidade de um ambiente respeitoso e "materno", de prover uma relação pela qual a criança paralisada pelo trauma pode desenvolver sua individualidade, reconhecer seus “fragmentos" - até então "estranhos" e "heterogêneos" (Borgogno, 1997/2004).

Ferenczi fala em como a criança traumatizada entra em um estado de obediência mecânica. Nesse sentido, pensamos no princípio do relaxamento, proposto em 1930, como essencial no lidar com esse tipo de paciente. A provisão de um ambiente seguro é o que permite uma repetição, não do trauma, como no caso de um analista rígido e punitivo que atualiza a situação de submissão, mas da experiência infantil anterior ao trauma, da possibilidade de conhecer o mundo e a si mesmo. A possibilidade de um relaxamento e o tato do analista são peças indispensáveis para se pensar a regressão enquanto ferramenta terapêutica nos casos marcados pela experiência traumática.

Pode-se afirmar, com razão, que o método que emprego com os meus analisados consiste em mimá-los. [...]. Prolonga-se a sessão de análise o tempo necessário para poder aplanar as emoções suscitadas pelo material; não se solta o paciente antes de ter resolvido, no sentido de uma conciliação, os conflitos 
inevitáveis na situação analítica, esclarecendo os mal-entendidos remontando à vivência infantil. [...]. Procede-se assim um pouco à maneira de uma mãe carinhosa. (Ferenczi, 1931/2011, p.89/90)

É, portanto, nessas ideias sobre o trauma e a regressão que vemos sua teoria se resolver. Foi a partir de seu olhar atento e curioso que Ferenczi pôde perceber, desde seu primeiro texto, quando olhou para as mulheres ao pensar a ejaculação precoce do homem, o lugar daqueles que não tinham lugar. O objeto enquanto veículo de descarga não é suficiente, há de se pensar a qualidade desses objetos que são integrados formando o Eu. Há de se pensar no vínculo. Há de se pensar na metapsicologia do analista que vai de encontro a esses pacientes enquanto sujeito em condição transferencial altamente suscetível de traumatizálos.

Ao priorizar em sua teoria os efeitos do ambiente no psiquismo, do analista sobre o paciente, Ferenczi inaugura um caminho relacional dentro da psicanálise que, tomando o trauma como exógeno, vê, também na relação paciente-analista, sua possível resolução. Na medida em que se percebe o perigoso poder do analista, torna-se possível, a partir de um manejo baseado em prudência, tato e sinceridade, uma ampliação da clínica. 
4.

\section{Balint e Winnicott: criação do novo a partir da experiência regressiva}

Neste capítulo abordaremos dois psicanalistas que, na esteira de Ferenczi, tomaram o ambiente, a relação, e as vivências primitivas como fundamentais para se pensar a clínica. Embora suas relações com Ferenczi sejam inteiramente diferentes, é inegável a influência que o mesmo exerceu em ambas trajetórias. Donald Winnicott, pediatra inglês, e Michael Balint, psicanalista húngaro, se unem em Londres onde ambos participam da Sociedade Psicanalítica Britânica e integram o Middle Group ou "grupo independente". Este grupo que inclui também John Bowlby e Ronald Fairbarn para citar alguns, destaca-se, sobretudo, por não se filiar nem a Melanie Klein nem a Anna Freud, que na época disputavam o posto de "mãe da psicanálise infantil".

Michael Balint, embora mais conhecido pelos "Grupos Balint 48 ", inicia sua carreira psicanalítica cedo, passando por lugares como Budapeste (onde nasceu) e Berlim antes de se erradicar na Inglaterra, onde atuou pela maior parte de sua vida. Essa bagagem húngara é considerada por Gurfinkel (2017) um fator diferenciador quando comparado aos colegas do Middle Group. Sándor Ferenczi, seu coterrâneo, foi um grande mestre e amigo e alguém a quem sempre se refere em suas obras. Com um espírito decididamente independente e inovador, seu trabalho expressa também um pesquisador atento e metódico que, ao propor novidades teóricas e técnicas, sempre dialoga tanto com Ferenczi quanto com Freud, fazendo articulações cuidadosas entre os pressupostos pulsionais e relacionais.

O britânico Donald Winnicott inicia sua carreira médica como pediatra no hospital infantil Paddington Green Children's Hospital. Cativado pela percepção de uma densidade da vida psíquica infantil e pelo seu próprio processo em análise, Winnicott $\log$ o se aproxima da psicanálise e, em especial, de Melanie Klein. Porém, ao longo dos seus quarenta anos de clínica foi cada vez mais desenvolvendo um caminho autoral, ao ponto de alguns nem mesmo o incluirem

${ }^{48}$ Grupos de supervisão médica criado com sua terceira esposa, Enid Balint. 
no campo da psicanálise. Essa rejeição se dá pelo fato de que Winnicott rejeitou ou deixou de lado conceitos freudianos tão importantes quanto, por exemplo, a pulsão e, em especial, a pulsão de morte. Em sua obra ele se atenta a aspectos biológicos da vida do bebê dando lugar às noções repugnadas por alguns psicanalistas de necessidade e instinto.

Devemos esclarecer ainda o que une os autores citados neste capítulo. Embora com produções de caráter extremamente distintos e com teorias que seguiram caminhos muitas vezes desencontrados, se assemelham na medida em que enfatizam e dão continuidade à possibilidade inaugurada por Ferenczi de se tomar a regressão como uma ferramenta analítica terapêutica. Ambos autores desafiaram o desaconselhamento de Freud no que diz respeito a permissão de se viver estados regressivos em análise. Veremos ao longo do capítulo como, através de um olhar relacional, tanto Winnicott quanto Balint desenvolveram uma teoria frutífera para se pensar a clínica contemporânea - a qual abordaremos no capítulo final.

\section{1}

\section{Uma reformulação da ideia de narcisismo}

Um dos conceitos norteadores da obra de Balint é o narcisismo. Amplamente compreendido como o movimento de investimento libidinal no eu, na medida em que fala de uma incipiente relação entre o eu e seu entorno se torna extremamente importante para os autores que pensam os primórdios do desenvolvimento. Embora em Freud o conceito tenha recebido maior atenção apenas no texto de $1914^{49}$, ele nunca deixou de estar presente em suas construções e, como Balint irá problematizar, de formas diferentes. O papel do eu e a erogenização do mesmo são pontos extremamente problemáticos na teoria freudiana. Não à toa, a conceitualização do narcisismo marca o abandono do primeiro dualismo pulsional e a necessidade da teorização de um segundo.

${ }^{49}$ Freud, S. (1914a/2010). Introdução ao Narcisismo. 
Em Balint, a problemática gira em torno em especial da noção de narcisismo primário, conceituado por Freud de maneiras distintas e mesmo contraditórias e, mais importante, nunca baseado em observações clínicas. Assim, ao exaltarmos a relevância do narcisismo para Balint, falamos na verdade da desconstrução que o conceito sofrerá em sua teoria. Esse rompimento dá lugar a uma concepção inovadora, sobretudo por sua assertividade, sobre as primeiras relações do sujeito com seu entorno. Mas, antes de apresentá-la, devemos entender as contradições percebidas por Balint entre as ideias de narcisismo primário, autoerotismo e relação objetal primária.

Balint foi, enquanto teórico, um leitor extremamente cauteloso. Percorrendo sua obra deparamo-nos frequentemente com pontuações de enorme relevância sobre problemas que outrora passaram despercebidos e, neste capítulo, teremos a oportunidade de chamar a atenção para duas delas: os conceitos de narcisismo e fixação. Comecemos pelo primeiro.

Segundo o autor, são muitas as concepções enquadradas sob o conceito de "narcisismo", e ele organiza três caminhos distintos que Freud teria apresentado para explicar a relação primitiva do eu com seu entorno. A primeira, introduzida no "Três ensaios sobre a teoria da sexualidade" (Freud, 1905b/2016), afirmaria haver, desde o início, um objeto fora do corpo. Seria apenas a partir dessa primeira relação com um objeto externo que a pulsão poderia retornar para o sujeito tornando-se, então, autoerótica. Este primeiro objeto seria buscado pelo resto da vida, de forma que o encontro com todo objeto seria, na verdade, um reencontro. Considerando que a esse trecho foi atribuida uma nota de rodapé em 1915 - ou seja, após a publicação do texto "Introdução ao narcisismo" (Freud, 1914a/2010) - que não modificava essa colocação, pode-se considerar que "Freud não teria tido a intenção de abandonar a tese de uma relação objetal precoce primária em benefício do conceito de narcisismo primário" (Peixoto Junior, 2013, p.20).

No texto de 1914 citado acima, encontramos ainda duas outras concepções acerca do narcisismo; uma delas é a de que esse processo seria um fenômeno intermediário entre o autoerotismo e a relação objetal. No início haveria no bebê 
um funcionamento exclusivamente autoerótico, de forma que o ego seria um produto resultante de uma "nova ação psíquica" (Freud, 1914a/2010), o investimento libidinal no eu. Apenas a partir dessa formação o sujeito poderia ir de encontro ao mundo objetal externo. Ou seja, a relação de objeto, que em "Três ensaios da teoria da sexualidade" (Freud, 1905b/2016) teria sido tratada como primária, passa a ser apresentada como posterior ao autoerotismo e à formação do eu.

Ainda outra descrição encontrada no mesmo texto se dá a partir da famosa analogia da ameba e seus pseudópodes ${ }^{50}$. Esta ideia reside na compreensão de que haveria um reservatório originário de libido a partir do qual se tornaria possível investir no mundo. É nessa teoria que encontramos a principal indicação de Freud no sentido de afirmar um "narcisismo primário" na medida em que coloca como primordial uma concentração libidinal que delimita o eu. Não fica clara, porém, a localidade topológica deste reservatório, ora se fala no Ego, ora no Id, em função das mudanças trazidas pelo estabelecimento da segunda tópica em 1923. De todo modo, ambas hipóteses parecem não resolver a questão. O Ego enquanto um reservatório original se opõe ao autoerotismo, que ocorreria também no princípio e enquanto manifestação sexual sem objeto. Mas se temos o Id como fonte de libido, é o que Freud define em 1923, não temos ainda um Ego para ser investido enquanto tal e, quando o temos, esse investimento há de ser considerado já secundário.

O que Balint expõe, portanto, é a incompatibilidade entre a posição teórica ocupada pelo conceito de narcisismo primário e seu embasamento clínico. Embora amplamente aceito como estado primordial do sujeito em relação ao mundo e ao próprio eu, não há, na obra de Freud, nenhuma descrição mais assertiva sobre essa vivência. Balint lembra ainda que Freud era tudo menos um teórico desatento de forma que, se foram deixados "pontos sem nó" no que diz respeito a teoria do narcisismo, foi porque Freud de fato não pôde resolvê-los. Ao

50 "Formamos assim a ideia de um originário investimento libidinal do Eu, de que algo é depois sedimentado aos objetos, mas que persiste fundamentalmente, relacionando-se aos seus investimentos de objeto como o corpo de uma ameba aos pseudópodes que dele avançam." (Freud, 1914a/2010, p.17) 
que parece, as contradições acerca sobretudo a ideia de narcisismo primário, foram deixadas de lado em pról de uma teoria organizada.

Balint sustenta, então, não haver motivo para se sustentar um conceito que, além de intrinsicamente incoerente, não é observável na clínica. Todos os exemplos expostos por Freud em 1914 (homossexualidade, megalomania psicótica, idealizações onipotentes da infância e o sono) são pelo húngaro considerados exemplos do narcisismo secundário, ou seja, de fenômenos de retorno da libido ao eu posteriores a um primeiro momento marcado por relações com o mundo. Nas palavras de Peixoto Junior:

Sendo assim, aquilo que Freud nomeou como narcisismo primário ou absoluto não passaria de uma hipótese que se poderia presumir, mesmo sem contar com nenhuma observação clínica que a comprovasse. Já o narcisismo secundário seria realmente passível de observação clínica e descreveria um estado na qual uma parte da libido que anteriormente investia os objetos externos seria retirada deles e voltaria para o ego. (Peixoto Junior, 2013, p.22)

Após essa breve exposição da problematização proposta por Balint, devemos apresentar o que ele propõe como solução. Tendo em vista os pontos de incoerência inerentes ao conceito de narcisismo primário, ele opta por deixá-lo de lado em pról de uma teoria sobre os primórdios baseada em experiências observáveis clinicamente e, por isso, mais eficaz. O que ele introduz é a ideia de primary love, que aqui usaremos como "amor primário".

O conceito aparece pela primeira vez no texto de 1937, "Estados primitivos de desenvolvimento do ego: amor objetal primário", no qual ele apresenta, não só sua compreensão do desenvolvimento das relações objetais, mas também sua ênfase na relação transferencial. É evidente, mesmo então, que o período mais primitivo da experiência é de grande relevância para a psicanálise. Pelas escolas de Londres, Viena e Budapeste se buscava conhecer essa gênese do sujeito. Restava, entretanto, saber como fazê-lo de maneira confiável. Duas opções se destacavam: por meio da observação dos bebês; e por uma reconstrução da infância já na vida adulta. Mas Balint traz ainda uma terceira opção, segundo ele, alcançada também por A. Balint ${ }^{51}$ e I. Hermann e baseada nos pressupostos de Ferenczi e Freud. Ele diz: "Nosso ponto de partida comum foi considerar os

${ }^{51}$ Psicanalista húngara e primeira esposa de Michael Balint. 
elementos formais da situação analítica, mais do que comumente se tem feito até agora, como fenômenos da transferência, na esperança de que assim obteríamos informação valiosa sobre a história individual de nossos pacientes" (Balint, 1937/2015, p.79).

A proposta vai na esteira de Ferenczi ao valorizar a atuação na relação e a repetição mais do que a rememoração. Nesse sentido, a noção de transferência, embora já colocada mesmo por Freud como campo de atuação de afetos importantes para o tratamento, é ampliada. Deixa de ser observada apenas como um mecanismo inconsciente regido pelos fenômenos de deslocamento e condensação para ser tomada como um vínculo que, pelas implicações tanto do analisando quanto do analista, indicam a qualidade daquela relação. A relação transferencial é tomada como indicativa do desenvolvimento das relações de objetos do sujeito e, assim, ilustra formas de relação primitivas até então pouco elucidadas pela observação ou rememoração. Na transferência elas são (re)vividas e, assim, explicitadas.

Essa nova forma de conceber e explorar a transferência se constrói a partir da - e ao mesmo tempo permite a - percepção das diferentes formas do paciente se dirigir ao analista. Essas variações chamam atenção por se manifestarem tanto nas diferentes análises quanto no mesmo paciente em momentos diferentes do tratamento, falam sobre estados em detrimento de um entendimento de uma forma fixa do sujeito. Esses estados ilustram, portanto, momentos diferentes do desenvolvimento nos quais o eu se dirige aos objetos do mundo de uma ou outra maneira. O que começa a chamar a atenção de Balint em especial é um estado intensamente demandante no qual alguns pacientes entram. Ele diz: "Descobri que, por vezes, quando o trabalho analítico avançara a um nível razoavelmente profundo, meus pacientes esperavam e frequentemente demandavam certas gratificações primitivas, principalmente do seu analista mas também do seu ambiente" (Balint, 1937/2015, p.80).

Observando esse tipo de interação ele chega a algumas conclusões sobre esse estado: primeiro que essas demandas são sempre dirigidas a um objeto 
externo e, segundo, que nunca ultrapassam o nível de um prazer preliminar ${ }^{52}$. Isso indicaria que, nesse estado, a satisfação só pode ser obtida a partir de uma relação, satisfações autoeróticas ou narcísicas se mostram insuficientes. Até aí, nada de muito novo. Esse tipo de relação se apresenta e é claramente infantil, regressivo, mas o que faria dele um estado mais primitivo, ao ponto de sustentar uma teoria substituta ao narcisismo primário?

Balint (1937/2015) adverte que, também o que ele propõe como substituto ao narcisismo primário é especulação, mas conta com duas diferenças que julga relevantes: 1- se apoia em evidências clínicas e; 2- é uma teoria afirmativa. Por afirmativa ele quer dizer que é um fenômeno que se define pela presença e manifestação de elementos e condições, diferentemente do narcisismo primário, que seria passível de definição apenas pela negação ou ausência de certos processos e, principalmente, pela anterioridade a eles.

Narcisismo primário é uma noção bastante curiosa, repleta de significado e, ainda assim, muito pobre. Se a aceitamos, o estado mais primitivo da vida extra-uterina pode ser definido da seguinte maneira: o infante não tem até então nenhum conhecimento do mundo externo, sequer o percebe; não tem, subjetivamente, nenhuma relação com os objetos ou pessoas de seu ambiente e, portanto, nenhum desejo dirigido ao mundo; ele experienciou apenas aumento e desaparecimento de suas necessidades, mas ainda não as vincula ao mundo externo; os fenômenos emocionais observáveis, como o chorar, choramingar, arranhar, agarrar, se inquietar por um lado, o sorrir e a tranquilidade por outro, são apenas ab-reações; já que o infante ainda não percebe nenhum objeto externo, não pode ter nenhuma relação de objeto libidinal ainda; de sua libido nada já se voltou externamente. (Balint, 1937/2015, p.86)

A hipótese de Balint pretende focar em um aspecto que, segundo ele, até então recebera pouca atenção. Opondo a escola de Vienna a de Londres ele alega que, apesar de muitos aspectos coincidirem, a segunda, ao pensar os primórdios, teria focado nas reações às frustrações, deixando de lado uma descrição mais cuidadosa da experiência primária mais silenciosa de tranquilidade e harmonia. É esta experiência que servirá de base para a proposição de Balint.

\footnotetext{
${ }^{52}$ No original a palavra utilizada é "fore-pleasure". Entendemos que o sentido intendido é de um prazer não total, ou seja, anterior ao prazer genital adulto. Optamos por usar a palavra "preliminar" mas talvez "parcial" também fosse uma possível tradução. A escolha se deu por pensar que o termo "parcial" costuma acompanhar a ideia de pulsão, ideia esta não explicitamente utilizada por Balint nesse texto. De todo modo, compreende-se que falamos das satisfações presentes na vida infantil anterior à entrada na fase genital.
} 
Ele explicita que essas ações seriam coisas simples, silenciosas, tal como um toque no analista, uma permissão para chamá-lo pelo primeiro nome. O que ele percebe é que, nessas situações, parece haver a busca pela revisitação desse estado primitivo no qual bebê e mãe são um só ser desejante, já que o desejo de um equivale ao do outro. Uma intimidade baseada na equivalência. Seria uma tentativa de alcançar o que Balint chamou de maior meta instintual: "a união com o objeto, a recuperação da identidade ego-objeto" (Balint, 1937/2015, p.84).

O que parece estar implicado nessa afirmação, é que pode haver na transferência a manifestação de um direcionamento libidinal ao objeto - uma vez que vai ao encontro do analista - que não se trata de um investimento erótico no sentido de um amor na transferência (Freud 1912a/2010). Falamos em uma relação objetal que antecede, portanto, o desenvolvimento erótico. Uma relação objetal primordial, anterior ao eu e anterior ao objeto mas, ainda assim, em relação com ele. Como isso é possível? Trata-se de uma relação de amor primário passiva, passiva porque vive em completo equilíbrio com o ambiente - a mãe. Seguem duas falas de Balint que podem nos auxiliar nesta compreensão:

Em minha opinião uma fase extra-uterina muito primitiva, provavelmente a mais primitiva, não é narcísica é dirigida a objetos, mas essa relação-objetal primária é uma relação passiva. Sua meta é basicamente essa: $E u$ devo ser amado e satisfeito, sem estar sujeito a nenhuma obrigação para dar nada em troca. ${ }^{53}$ (Balint, 1937/2015, p.82).

O resultado mais importante embora de forma alguma inesperado é que ambas partes dessa relação são libidinalmente iguais. Libidinalmente a mãe é receptora e doadora na mesma medida que sua criança; ela experiencia seu bebê como parte de seu próprio corpo e ainda como algo estranho e hostil da mesma maneira que a criança reconhece o corpo de sua mãe. (Balint, 1937/2015, p.83).

Ainda no mesmo texto Balint elenca, a partir de estudos de Alice Balint, algumas características desse estado do "amor primário" que podem nos ajudar a alcançar a definição afirmativa que foi pra ele tão importante. Vamos a elas: 1ocorre muito cedo; 2- é inevitável e absolutamente necessária para o desenvolvimento subjetivo; 3- não pode ser associada a nenhuma zona erógena, é uma forma de amor em si como o autoerotismo, o narcisismo e o amor objetal ativo; 4- a base biológica dessa relação objetal é a interdependência entre mãe e

${ }^{53}$ Grifo do original 
bebê; 5- é uma relação íntima e com interrupção exercida pela cultura cedo demais, o que explicaria nossa tendência a se "agarrar ${ }^{54 "}$ aos objetos; e 6- se satisfeito nunca ultrapassa um prazer preliminar, se frustrado pode gerar consequências barulhentas. Acreditamos que esse conjunto de particularidades seja suficiente para ilustrar o que Balint apresentou como conceito substituto ao narcisismo primário.

Por fim, devemos endereçar ainda o narcisismo enquanto fenômeno secundário. Como já foi dito, o ponto problematizado por Balint sobre o investimento libidinal no eu não é sua existência mas seu momento no desenvolvimento. Para ele esse fenômeno é facilmente percebido na clínica e em vivências cotidianas, como no sono, mas se buscamos sua origem, ela é posterior a uma relação objetal primária. Mais especificamente, Balint (1935/2015) introduz a ideia de que não só ela é posterior mas consequência dessa primeira relação, ou melhor, da interrupção dela. Na realização da frustração de não ser apenas amado e gratificado pelo mundo o narcisismo se apresenta como uma saída: "se o mundo não me ama o suficiente, eu tenho que amar e gratificar a mim mesmo $^{55 "}$ (Balint, 1935/2015, p.50). Ou seja, o primeiro modelo de unidade de existência é um de inteira harmonia, quando esta se rompe, o ego se forma como resposta, o narcisismo se apresenta como tentativa de restituir a unidade rompida: "Quando a relação desenvolvida com parte do entorno ou com o objeto entra em contraste com a harmonia anterior, a libido retorna ao ego e inicia ou acelera seu desenvolvimento, na tentativa de recuperar a sensação anterior de unidade" (Peixoto Junior, 2013, p.36). Outras consequências desse rompimento precoce seriam o desenvolvimento da agressividade e do ódio. Sobre isso Peixoto Junior nos diz:

Caso ocorra algum obstáculo ou desarmonia, a reação consiste em sintomas ruidosos e intensos de natureza destrutiva, agressiva ou profundamente desintegrada, como se o mundo inteiro, incluindo o próprio ego, tivesse rompido-se

\footnotetext{
54 No original o termo utilizado é o verbo "to cling". Traduzimos pelo verbo "agarrar" sabendo que a tradução se mostra insuficiente. Outras traduções possíveis e que servem para ampliar a compreensão do sentido original são: segurar, ligar-se a, apegar-se, unir-se. Esses últimos talvez facilitem a articulação que o conceito propõe entre essas formas de relação objetal e a relação objetal primária, na qual bebê e mãe experienciam um estado de união como um só.

55 Grifo do original
} 
ou como se o sujeito tivesse sido engolfado por impulsos agressivos e destrutivos puros. (Peixoto Junior, 2013, p.36)

Tudo isso nos será essencial na medida em que avançamos na compreensão dos fenômenos regressivos na clínica. Em Balint, será o reencontro com esse estado de amor primário passivo na vivência com o analista que propiciará ao paciente uma possibilidade de novo começo. Devemos guardar, portanto, as particularidades desse estado bem como o fato de ter sido percebido através da transferência. A relação com o analista e as vivências em análise ficarão cada vez mais indissociáveis. Se falamos em relações de objeto é preciso que o analista esteja presente e consciente de seu lugar. Citemos mais uma vez Peixoto Junior para seguirmos em frente:

Neste sentido graças à regressão terapêutica, como veremos adiante, seria possível reencontrar em um primeiro tempo a relação de objeto passiva, para apenas em um segundo momento, engajar-se em modos de relação objetal ativas, o que proporcionaria ao sujeito um novo começo em sua vida afetiva. Este seria um novo campo de investigações que Balint pressentia escapar à teoria ortodoxa. (Peixoto Junior, 2013, p.30).

\section{2}

\section{As três áreas da mente e as diferentes relações de objeto}

O que faz com que um paciente funcione com um analista e não com outro? O que acontece quando as interpretações deixam de fazer efeito ou mesmo deixam de ser percebidas enquanto tal? É a partir dessa ordem de questão que Balint desenvolve uma nova possibilidade de topologia da mente. Diferentemente do que vimos em Freud, tópicas que descrevem a dinâmica pulsional intrapsíquica, Balint (1968/1992) retrata um sistema que discrimina áreas da mente em função das diferentes formas pelas quais o indivíduo interage com seus objetos e seus meios. Podemos dizer então que ele constrói uma esquematização relacional e não pulsional do funcionamento psíquico.

O problema se apresenta a partir de impasses clínicos. Situações da relação analítica convocam o autor a refletir sobre as diferentes interações entre paciente e analista e sobre os efeitos das ações do segundo sobre o primeiro. As diferentes dificuldades experienciadas pelos analistas fazem ele questionar: "Quais são as 
partes da mente nas quais o processo analítico se dá?" (Balint, 1968/1992, p.4). Seguindo os passos de Ferenczi, que já evidenciavam a relevância dos processos internos do analista na análise, Balint mergulha nos limites e impactos das intervenções do terapeuta para tentar compreender o porquê dos pacientes se portarem de formas tão distintas diante uma mesma técnica. O que ele conclui é que as variâncias se dão em função da existência de diferentes áreas da mente, e a técnica clássica se apoiaria sobre apenas uma delas, deixando de levar em conta outros tipos de funcionamento frequentemente acessados pelos sujeitos em análise. As três áreas por ele nomeadas são a área da criação, a área da falha básica e a área edipiana. A técnica freudiana operaria no registro da terceira. Comecemos então por uma descrição desta, com a qual já somos mais familiarizados.

Ao nível edipiano Balint associa, sobretudo, a ideia de conflito. Isso porque as relações são sempre triangulares, incluindo o sujeito e pelo menos dois objetos paralelos. Para ele, a situação que melhor exemplifica o que ele está chamando de conflito seria aquela na qual "uma autoridade - externa ou interna - prescreve, ou proíbe, uma forma particular de gratificação" (Balint, 1968/1992, p.16). Isso resultaria em uma fixação de libido cuja tensão poderia ser aliviada em análise, por exemplo por meio de uma interpretação. Nesses casos, a interpretação, que exige a priori um domínio do conteúdo da linguagem adulta (pré-genital ou genital), seria um recurso técnico eficiente. Poderia se dizer que ambos paciente e analista compreendem a linguagem que está sendo utilizada, as palavras têm significado semelhante para os dois.

Há, porém, casos nos quais as interpretações ou não têm efeito ou têm um efeito completamente diferente do intendido. Com frequência os analistas associam esse fracasso à resistência do paciente, mas Balint propõe uma nova hipótese que se aproximaria do que já teria sido elaborado por Ferenczi em seu texto "Confusão de línguas entre os adultos e a criança" (Ferenczi, 1933/2011). Para ele, o que ocorreria seria como um "golfo entre paciente e analista" em função de uma incapacidade do paciente de compreender o sentido da linguagem utilizada pelo analista, interrompendo, portanto, a possibilidade de uma 
assimilação e elaboração do material oferecido. É esse tipo de impasse que o faz pensar em uma outra área da mente que pode atuar durante o processo analítico, uma área que se utiliza e se comunica através de uma linguagem anterior à edípica, a do conflito.

Adentramos então a área da falha básica. Esse nível corresponde, necessariamente, a relações bipessoais, ou seja, nas quais existem apenas o sujeito e um objeto. Esse tipo de relação é inteiramente diferente daquela mais conhecida, compatível com o nível edipiano, já que a natureza da força dinâmica não é a de um conflito mas de uma falha. Essa é uma das características usadas por Balint para explicar a escolha do nome.

Todos esses eventos pertencem essencialmente ao campo da psicologia de duas pessoas e são mais elementares do que aquelas pertencentes ao nível edipiano, de três pessoas. Além do mais, eles carecem a estrutura de conflito. Isso foi um dos motivos pelo qual eu propus chamá-los de 'básico'. Mas por que falha? Primeiro, porque essa é exatamente a palavra usada por muitos pacientes para descrevê-la. O paciente diz sentir haver uma falha inerente a ele, uma falha que deve ser corrigida. E isso é sentido como uma falha, não um complexo, não um conflito, não uma situação. Segundo, existe uma sensação de a causa dessa falha ser que alguém ou falhou com ele ou o negligenciou, e terceiro, uma grande ansiedade invariavelmente circunda essa área, frequentemente expressa como uma demanda desesperada de que desta vez o analista não deve - na verdade não pode - fracassar com ele. (Balint, 1968/1992, p.21) ${ }^{56}$

Ou seja, ao falarmos no nível da falha básica estamos sempre referidos a situações mais primitivas e, por isso, mais fundantes. Nesse sentido, Balint chama a atenção para as marcas deixadas também no corpo, que na altura desta vivência ainda não está integrado e genitalizado como no nível edipiano. Cabe aqui acrescentar outro ponto importante: a vivência da relação bipessoal da falha básica é marcada por reações inteiramente diferentes às experiências de satisfação e frustração. As satisfações são vividas de maneira silenciosa e tranquila. Entendendo tratar-se de um período muito primitivo, elas são como que representantes de uma atenção básica, absolutamente necessária até mesmo biologicamente. As frustrações, por sua vez, são extremamente ruidosas. Na

\footnotetext{
56 Traduzimos "fault" por "falha" e "default" por "negligência" entendendo que enquanto a primeira refere-se a uma falha cometida por uma pessoa presente a segunda aludiria a uma falha que implicaria uma posição de ausência. Ou seja, fala-se por um lado de um erro cometido por um cuidador e por outro um erro que seria em si a ausência desse cuidador.
} 
medida em que representam o não atendimento de necessidades fundantes, podem gerar sintomas nada discretos.

Estamos acostumados na psicanálise a lidar com a ideia de conflito. Frequentemente trabalhamos em termos de desejos a serem satisfeitos, embates a serem resolvidos. Precisa ficar claro que a falha básica, entretanto, fala de outra dinâmica psíquica, fala de uma deficiência a ser cuidada, de, nas palavras de Balint (1968/1992), uma "cicatriz indolor". É uma questão necessariamente relacional que não pode ser compreendida por um viés meramente intrapsíquico, um conflito entre instâncias. Há, necessariamente, um objeto externo que responde de uma ou outra maneira ao sujeito e, nesse sentido, a qualidade do objeto importa, vai além de sua viabilização de uma descarga pulsional. A ênfase está no que Balint (1968/1992) chamou de fit entre sujeito e objeto, criança e ambiente, paciente e analista. É, portanto, um nível psíquico que fala de um estado primordial que visa, sobretudo, a harmonia. Fica explícita assim, a relação entre falha básica e a ideia de amor primário já apresentada neste capítulo. Peixoto Junior (2013) fala dessa relação: "a natureza dessa relação bipessoal primitiva pode ser considerada como uma instância da relação objetal presente no amor primário, ao qual fizemos referência antes, e qualquer terceiro que nela interfira tende a ser sentido como um pesado encargo ou uma força intolerável" (Peixoto Junior, 2013, p.59).

Retomando a noção de amor primário, para se falar da área de falha básica cabe dizer que, embora estejamos chamando a atenção para o fato de que nesse contexto as relações são sempre bipessoais, não à toa falamos em um sujeito e seu objeto. Apenas um dos integrantes da relação pode desejar, o outro serve apenas para gratificar o primeiro. É desta compreensão que acessamos a função materna e a função do analista no trato com pacientes regredidos na teoria balintiana. Para o autor, trata-se não de uma interdependência pulsional mas de uma relação de interpenetração na qual, em um primeiro momento, a experiência é a de uma mistura harmoniosa provida pela mãe acolhedora mas antes mesmo dela existir enquanto objeto. Esta mistura seria o último objetivo almejado pelo sujeito: "Aquela da experiência fetal concreta, remanescente como experiência ou única 
vivência possível, excluída de qualquer sistema sujeito-objeto, de emergência ulterior" (Peixoto Junior, 2013, p.53)

Agora nos parece importante explicitar como essa área e os aspectos dessa primeira relação se apresentam clinicamente. Balint diz que o alcance dessa área em análise é revelado a partir de uma drástica e repentina mudança na atmosfera do trabalho. Em suas palavras:

Partindo de um caso razoavelmente normal, vamos supor que o tratamento vem correndo suavemente há um tempo, paciente e analista compreendem um ao outro, ao passo que as tensões e demandas sobre qualquer um deles, mas especialmente sobre o analista, são apenas razoáveis e, mais importante, sempre inteligíveis. Então em algum momento, de repente e insidiosamente, a atmosfera da situação analítica muda profundamente. (Balint, 1968/1992, p.18)

Algumas características ilustram essa mudança: as interpretações do analista não são experienciadas enquanto tal; as palavras, que até então ocupavam um lugar comum de compreensão, passam a ser destacadas, seja para o bem ou para o mal; qualquer ação do analista, seja ela uma fala, um gesto, um movimento, parece ganhar peso; o paciente se mostra mais sensível ao analista, sabendo coisas sobre ele que ele antes não poderia saber e; diante uma ação indesejada do analista ele não reage com raiva, como na área do conflito, mas com uma sensação de vazio, de desvitalização.

Isso tudo se passa pelo lado do paciente, mas há também uma experiência particular vivida pelo analista que, se atento aos seus processos psíquicos internos, como Ferenczi aconselharia, o auxiliará a manejar esses casos. Segundo Balint (1968/1992), a sensação é de que tudo na relação terapêutica de repente o toca mais de perto, a postura que costuma ser de uma passividade, se torna mais difícil de sustentar e ele se vê em constante risco de ceder a um envolvimento emocional subjetivo. A partir do que temos visto, isso se daria em função de uma regressão do paciente a este nível no qual o outro da relação está ali para gratificá-lo, de forma que o analista se vê nesse lugar de responder a uma demanda primária do paciente. Veremos mais à frente o desenrolo desta relação. Importante, porém, mais uma vez exaltarmos que a implicação do analista enquanto sujeito ativo na relação é medular para se compreender a teoria balintiana. A contratransferência 
aparece como fundamental para se compreender os processos vividos também pelo paciente.

A despeito da área da falha básica, caberia por fim dizer, que ela é a de maior importância para nós na medida em que é nela que se dá o fenômeno da regressão em análise. Ou melhor, é via os movimentos regressivos a esta área, a este tipo de relação - bipessoal e primitiva -, que torna-se possível para o sujeito, dependendo do manejo do analista, elaborar essa falha básica. Peixoto Junior (2013) diz que "a falha básica seria uma ferida que eventualmente pode cicatrizar, mas que não pode ser suprimida" (Peixoto Junior, 2013, p.51). Entendemos que o manejo dessa regressão em análise seria um meio para esta cicatrização.

Dissemos anteriormente, a respeito do amor primário e também do nível da falha básica, que nesses estados as relações são sempre bipessoais, sendo um terceiro percebido como um invasor, um opressor à harmonia vigente. De todo modo, é evidente que, mais cedo ou mais tarde, essa relação interpenetrante há de se dissolver. Os casos tratados por Balint como se passando no nível da falha básica aludem a uma frustração, uma falha mesmo, ocorrida nessa relação dual primeira. Nesse sentido, trazem à tona sintomas mais tumultuosos e explicitam uma desvitalização em função de uma insuficiência dessa primeira experiência de amor e harmonia. Porém, mesmo aqueles que carregam a vivência de falhas menos extremas se mostrarão marcados por esse processo de descoberta do ambiente e de objetos que desejam por si só. É a partir desta compreensão que Balint desenvolve dois conceitos que pretendem descrever diferentes tendências de resposta a esse momento de surgimento dos objetos. Eles são: ocnofilia e filobatismo.

A ocnofilia vem do grego okneo, que significa agarrar-se, aferrar-se, segurar-se com força (Peixoto Junior, 2013, p.38). Já o filobatismo sugere a ideia do acrobata, "que caminha pelas extremidades, na ponta dos dedos, longe da terra firme" (Peixoto Junior, 2013, p.38). Logo, diante a emergência dos objetos, uma tendência é a de agarrar-se a eles, os tomando como seguros, e a outra é a de, ao percebê-los como perigosos e traiçoeiros, desenvolver-se da forma mais independente possível. Essencialmente o que está em questão é que os dois tipos 
representam diferentes experiências de prazer e de angústia quando em relação com os objetos. Entretanto, é importante notar desde já, que uma tendência não anula a outra, na verdade todos teriam uma mistura de ambas. Além disso, segundo Peixoto Junior (2013), coincidem também no fato de terem como característica uma ambivalência fundamental. Na medida em que são tentativas de superação do traumático fim da situação primitiva básica do amor primário, guardam em relação aos objetos sentimentos de amor e de ódio. Amor porque precisam deles, ódio porque eles podem precisar de outras coisas.

Cabe agora, porém, aprofundarmo-nos em suas diferenças. Apesar de se encontrarem na ambivalência, já deve estar claro que o amor e ódio que sentem perante os objetos externos são de naturezas distintas:

\begin{abstract}
Essas atitudes ambivalentes de ambos os tipos subjetivos são fruto de experiências ocorridas no decorrer da instalação do princípio de realidade, após um período primário de amor, em que sujeito e objeto ainda não estão diferenciados e a relação com o mundo é vivida como uma intromistura harmoniosa de substâncias. Nos primeiros estágios do teste de realidade, em que é preciso distinguir os mundos interno e externo e o que os causa, ambos, filobata e ocnofílico, parecem reagir da mesma maneira. $\mathrm{O}$ que os diferencia é a interpretação dada ao ambiente: enquanto o primeiro considera-o adorável, o segundo tem sentimentos horríveis com relação a ele, apesar da primitiva experiência prazerosa. Desta forma, ainda que o mundo externo seja o mesmo para os dois, seus mundos internos diferenciam-se, radicalmente, neste caso. (Peixoto Junior, 2013, p.46)
\end{abstract}

Ocorre que o ocnofílico, ao deparar-se com os objetos reais do mundo, os percebe como seguros e tranquilizadores, evitando, aí sim, os espaços amedontradores entre eles. Defrontado com a emergência dos objetos, ele sente uma angústia de separação dos mesmos, ao que responde com uma "adesividade". Já o filobata, ao perceber que existem objetos com desejos e movimentos próprios, os toma como não confiáveis e opta por desenvolver suas próprias funções do ego em uma tentativa de manter-se forte independente de objetos.

Devemos considerar ainda um outro ponto interessante, este é o fato de o filobatismo incluir pelo menos um objeto ocnofílico. Ou seja, na constante tentativa de manter-se "ereto", ele como que adota um único objeto no qual deposita sua confiança e que irá acompanhá-lo como símbolo de sua potência. Podemos dizer que esse objeto é, ao mesmo tempo, símbolo inconsciente do falo e do amor materno. 
Essas tendências são, enfim, as maneiras encontradas de negar a liberdade dos objetos, em especial da mãe, que garantia a harmonia da experiência primordial. Diante desta realidade inegável, há de se iludir de uma ou outra maneira. Seja pelo recurso ocnofílico de se manter colado a um objeto específico sempre que possível, seja pelo meio do filobata:

Já o filobata vive a ilusão de que a liberdade proporcionada pelo apego exclusivo a seu equipamento de circulação pelos espaços vazios - nos quais confia na medida em que tais espaços são compostos por objetos escolhidos - o garante contra os perigos oferecidos pelos outros objetos ameaçadores do mundo (dos quais ele desconfia), mantendo-o seguro. (Peixoto Junior, 2013, p.42)

Por fim, devemos abordar brevemente a área por Balint chamada de área da criação. Por ser uma necessariamente vivida de maneira individual, se torna inacessível a uma observação externa e, portanto, carece de uma definição mais assertiva. Não sendo acessível via transferência, nem observação ou rememoração, a descrição desta área se torna a princípio mais especulativa. Sua principal característica é de que nela ainda não há objeto externo. Neste nível lidamos com pré-objetos que, pela criação, podem vir a se tornar objetos totais e passíveis de interação - seja entre os objetos internos ou externos. Assim, a criação, ao qual o nome da área se refere, pode ser a de um objeto - mas não necessariamente. Balint diz que a preocupação do sujeito neste nível é menos a de produzir um objeto mas a de produzir algo por si mesmo. É um nível que tem como força dinâmica as ligações, os processos, e não visa um resultado. Clinicamente, o que temos é que, por vezes, um silêncio por parte do paciente pode não se tratar de um caso de resistência mas de um processo de criação em um ambiente seguro (Peixoto Junior, 2013, p.57).

Tendo apresentado a topologia esboçada por Balint, podemos seguir adiante a fim de explorar suas contribuições no que diz respeito o manejo clínico de estados regressivos. Veremos como seu pensamento relacional, que como vimos desmembra o funcionamento psíquico em função de seus níveis de relação de objeto, serve para compreender o que o paciente busca obter do analista e do trabalho analítico. A transferência enquanto deslocamento de libido para pessoa do médico se mostra insuficiente. É inegável que há um vínculo, um investimento 
pulsional no analista mas que tipo de vínculo é esse? Para Balint essa resposta será obtida a partir das percepções contratransferenciais e será essencial para atravessar as diferentes fases de um tratamento e os mais distintos dos pacientes.

\section{3}

\section{O manejo das regressões}

Enfim, chegamos ao tema da regressão. Esse conceito é central na obra de Balint e a presença do autor neste trabalho se dá sobretudo por este motivo. Com um lugar menos definitivo na teoria psicanalítica do que os outros autores aqui apresentados, comumente é o aprofundamento na questão da regressão como processo terapêutico que o leva a ser estudado. Talvez um primeiro ponto a ser exaltado deva ser o fato dele distinguir esse fenômeno clínico em dois tipos, um benigno e um maligno. Este aspecto marca sua originalidade na medida em que nos outros autores há sempre uma inclinação menos matizada, seja para a aceitação ou o desaconselhamento do processo.

Como já fizemos ao falar do conceito balintiano de "amor primário", parece também aqui caber uma alusão à crítica feita por Balint à concepção de regressão em Freud. Cabe dizer, entretanto, que diferentemente da crítica feita ao narcisismo primário, no caso da regressão Balint não rejeita a proposta freudiana mas defende que novos caminhos vividos na clínica devem ampliá-la. Ele começa retomando a multiplicidade do conceito (mecanismo de defesa, forma de resistência, fator decorrente do trabalho analítico e mecanismo patológico) para mostrar como se tratara sempre, necessariamente, de experiências intrapsíquicas. Peixoto Junior (2013) nos diz: "Mas enquanto em Freud a regressão permanece fundamentalmente intrapsíquica, em Balint ela será vinculada à teoria das relação de objeto e à psicologia a duas pessoas, tanto no campo teórico quanto na prática psicanalítica" (Peixoto Junior, 2013, p.63/4). A proposta vai no sentido de afirmar que, ao ser percebida enquanto vivência intersubjetiva, a regressão pode sair de seu lugar patológico e perigoso e passar a ser manejada enquanto oportunidade de atualização de cicatrizes inacessíveis por meio das intervenções interpretativas. 
As cicatrizes às quais nos referimos seriam aquelas que chamamos de indolor ao falar da área da falha básica. Assim, a compreensão é de que a regressão, benigna, seria um retorno - em termos de atmosfera, de forma de relação de objeto - ao tipo de amor atribuído à área da falha básica. $\mathrm{O}$ paciente buscaria na relação com o analista a experiência harmônica que apresentamos como primeira forma de relação objetal passiva. O retorno a este estado de amor primitivo, se bem manejado, viabilizaria o desenvolvimento de um "novo começo 57 ", de novas formas de se relacionar com os objetos do mundo. Esmiuçaremos esta ideia mais adiante.

Por outro lado ao falarmos da regressão maligna tratamos de estados que, alcançando um estado mais primitivo, não parecem ir além das formas de relações com objetos totais ou parciais. Isto porque, na relação com o analista, expressam o objetivo de gratificarem seus impulsos pulsionais, ou seja, o incluem em sua experiência subjetiva como representante de um mundo externo passível de satisfazer seus desejos. Transferencialmente isso se manifesta de forma muito distinta da primeira forma de regressão já que, ao perceber o analista enquanto unidade diferenciada, a atmosfera não é aquela de calmaria e harmonia mas sim intensa e apaixonada. Falamos, portanto, de pacientes que, apesar do estado regredido, se relacionam via a dinâmica edípica do conflito, convocando o analista para o atendimento de demandas primitivas mas sempre através de uma linguagem adulta.

Independente do tipo de regressão fica já aparente a importância dada ao lugar do analista nesta experiência. Como veremos, Balint defende que a contratransferência é indispensável para a compreensão do tipo de paciente com o qual se lida e, como consequência, da melhor forma para responder a ele. Longe de ocupar uma posição especular, para Balint o analista, sobretudo quando trabalhando na área da falha básica, será descrito como um informante, um tradutor ou um intérprete. Falando do paciente que se encontra regredido a esse nível ele diz: “Como todas essas 'comunicações' são não-verbais, somos nós

57 Tradução do original "new beginning". 
analistas quem devemos agir como intérpretes ${ }^{58}$ entre a consciência adulta do paciente e seus impulsos inconscientes" (Balint, 1968/1992, p.96). Ele continua:

Nessa situação nosso papel é semelhante àquele de um viajante visitando uma tribo primitiva, da qual a língua ainda não foi estudada, da qual costumes ainda não foram testemunhados, ainda menos registrados em termos objetivos. É o trabalho do informante chamar atenção para as partes relevantes daquele comportamento particular e descrevê-lo em sua importância em uma língua compreensível. Esse trabalho duplo - informante e intérprete ${ }^{59}$ - é inevitável, seja para contribuir para o avanço da ciência ou meramente para ajudar nossos pacientes $^{60}$. (Balint, 1968/1992, p.97).

Nos recortes apresentados somos aproximados de ainda outro aspecto importante do estudo de Balint: a linguagem. Como seguidor de Ferenczi, somos levados a perceber as influências do texto de 1933 (exposto aqui no capítulo anterior) "Confusão de línguas entre os adultos e a criança" em seu trabalho. A impressão é de que sua teoria tenta ampliar esta ideia das diferentes línguas ao longo do desenvolvimento para pensar tanto as relações primitivas como a analítica, como também Ferenczi fizera.

Tomando o que já apresentamos sobre as diferentes áreas da mente e suas diferentes formas e possibilidades de comunicação, Balint irá se questionar sobre como sabemos, enquanto analistas, quando o paciente está funcionando psiquicamente segundo a área da falha básica. Como já vimos, ele descreve uma mudança de atmosfera repentina na qual a técnica clássica, baseada na associação livre e na interpretação, parece não mover o trabalho. A sensação, por parte tanto do paciente quanto do analista, seria a de que não falam a mesma língua. Assim, é o analista quem deve ir de encontro à linguagem passível de entendimento por parte do analisando. É neste sentido que Freud julgara a aceitação da regressão terapêutica, ou melhor, o atendimento das demandas do paciente, que necessariamente apareceriam, um fenômeno clínico perigoso. Para ele, a permissão desta condição facilmente levaria o paciente a uma dependência excessiva em relação ao analista.

\footnotetext{
${ }^{58}$ Grifo do original

59 A palavra encontrada no original é a do inglês "interpreter". Optamos por traduzí-la por intérprete mas compreendemos que seu significado no português vai de encontro ao da palavra "tradutor".
} 
Para Balint, porém, a compreensão é a de que, reagindo a essas demandas primitivas por meio da interpretação, não só não se teria nenhum efeito analítico como poderia ter um valor traumático na medida em que reproduziria a situação infantil de não compreensão. Estando o paciente em um estado de não reconhecimento dos objetos enquanto externos e totais, uma interpretação poderia ser percebida como invasiva e hostil, inviabilizando qualquer possibilidade de confiança no ambiente. Importante explicar porém, que o atendimento dessas demandas não é uma disponibilidade indiscriminada mas a compreensão fina de necessidades não verbalizadas. Alguns exemplos seriam sessões extras, sessões mais longas, a permissão de um toque, chamar o analista pelo primeiro nome ${ }^{61}$, etc. De todo modo, Balint reconhece sim o perigo da aceitação desses estados regredidos e usa a ideia de regressão maligna para falar de situações nas quais essas demandas acabam por tornarem-se infindáveis e se associam mais a um uso abusivo de objeto do que à experiência de um novo começo.

Partindo da compreensão de que para Balint a regressão é a emergência, no contexto do tratamento, de formas mais primitivas de funcionamento, a forma pela qual o analista responderá às demandas que se apresentam será sempre baseada em uma percepção contratransferencial. Se entendemos essas formas primitivas como algo que se explicita nas relações de objeto, o que temos de maior dado sobre a idade da "criança no paciente" é a forma como o analista percebe a atmosfera que se materializa ali no trabalho terapêutico. É nesse sentido que a aceitação de um estado regressivo e a distinção entre uma regressão benigna ou maligna será sempre um processo intersubjetivo. Uma vivência que só pode ser experienciada e mesmo identificada na relação. Aqui nos afastamos cada vez mais da concepção freudiana que, como vimos, compreendia a regressão como um processo intrapsíquico.

No livro “A Falha Básica” (1968/1992), Balint dedica alguns capítulos a ideia de um "golfo" entre paciente e analista. A imagem trazida pretende expressar que em certos pacientes há uma distância entre os dois integrantes da análise que,

\footnotetext{
${ }^{61}$ Devemos aqui levar em conta que se tratava de uma clínica ocorrida nos anos 50 na Inglaterra. Embora isso possa parecer normal nos dias de hoje, tratava-se da concessão de um nível de intimidade.
} 
para que possam ser compreendidos um pelo outro, deve ser aproximada por uma ponte. Esta ponte, porém, não pode ser construída sozinha. Ele diz:

Nós sabemos que há dificuldades consideráveis quando a 'criança em nosso paciente' está na idade do complexo de Édipo. Mas o golfo separando nós adultos da 'criança em nosso paciente' da idade da falha básica - o 'infante' no verdadeiro sentido da palavra, em outras palavras, aquele que não pode falar, a qualquer custo, a língua dos adultos - é consideravelmente mais profundo e mais largo do que qualquer coisa encontrada no nível do complexo de Édipo no qual, afinal, todos usam uma linguagem convencional acordada. Apesar dessa dificuldade aumentada, o golfo separando paciente e analista deve ser transposto $^{62}$ se o trabalho terapêutico quiser continuar. Deve ser realizado, entretanto, que o paciente - isto é, 'a criança no paciente' da idade da falha básica - é incapaz de transpor esse golfo sozinho. (Balint, 1968/1992, p.90)

Nesses casos caberia ao analista perceber a necessidade do paciente e ir ao encontro dela. É nesse sentido que entendemos que, quando se trata de uma regressão tão profunda quanto à área da falha básica, o analista deve sim atender algumas demandas anunciadas pelo comportamento do analisando. Enfatizamos mais uma vez que essas demandas se dão de forma não-verbal, o que é, por si só, um indicativo de que a área da falha básica foi alcançada.

Balint (1968/1992) nos lembra também que todos os pacientes regridem em algum momento da análise mas haverá uma variância em termos de intensidade, duração e resposta do analista - que não pode ser desconsiderada. Sob a lupa da psicanálise clássica, todos estes processos regressivos poderiam ser descritos como um exagero da neurose ou do amor de transferência, mas há estados nos quais seu alcance é tão intenso e tão distinto que a técnica clássica já não mais serve. Assim, na medida em que a técnica da neurose de transferência falha, devemos abordar esses estados como representações de formas outras de relação de objeto. Isso não quer dizer que não se trata de uma vivência transferencial mas sim que expande a ideia de transferência balizada pelas relações edípicas - sejam elas genitais ou pré-genitais.

O caminho de Balint vai no sentido de compreender por que certos pacientes regridem a estados tão primitivos e como o analista deve responder nestas condições. Começaremos abordando esses estados em sua condição

\footnotetext{
62 No original a palavra utilizada é "bridged", que é ao mesmo tempo um verbo que passa a ideia de união e uma conjugação verbal do substantivo "bridge" que em português quer dizer "ponte". Não encontramos uma palavra no português que desse conta dos dois sentidos.
} 
considerada benigna, que levam ao desenvolvimento de novos começos. Peixoto Junior (2013) diz:

Durante a análise, na segurança proporcionada pela relação transferencial, o sujeito parece abandonar temporariamente suas defesas para regredir a um estado ainda não defendido, ingênuo, ou melhor, pré-traumático, e começar novamente a amar e odiar de um modo primitivo, que é rapidamente seguido pelo desenvolvimento de modalidades relacionais mais satisfatórias por serem pouco conflituosas. (Peixoto Junior, 2013, p.83)

A distinção de nomenclatura que qualifica este tipo de regressão como benigna pode ser compreendida se designamos esta como terapêutica e aquela, a maligna, como contraprodutiva no processo de uma análise. Esta diferenciação convoca porém a pergunta de qual seria o objetivo de uma análise. Peixoto Junior nos diz o seguinte:

a tarefa terapêutica fundamental de um processo analítico seria livrar o sujeito de suas diversas condições compulsórias de amar e odiar, que resultam de equívocos ocorridos no seu processo de criação quando criança. O objetivo, neste caso, é reverter o efeito desses equívocos e ajustar de maneira bastante flexível a relação do sujeito com a realidade, preservando ao máximo sua liberdade interna. (Peixoto Junior, 2013, p.76)

Assim, a regressão benigna seria a vivência que viabilizaria a superação de conflitos infantis que deixaram como marca limitações nas possibilidades de amar. Devemos entendê-la como um processo dinâmico que, vivido em plena confiança na relação analítica, permite a reelaboração desses conflitos infantis criando novos destinos para as fixações e as barreiras levantadas por eles. Neste sentido vemos semelhança com a ideia de Freud que concebe a regressão como um retorno a pontos de fixação no desenvolvimento da libido mas, diferentemente do mesmo, Balint pensa a fixação como um trauma que afeta o desenvolvimento em suas formas de se relacionar com o mundo. Não são fases que são ou deixam de ser superadas mas formatos enrijecidos que limitam a potência do sujeito. E, mais importante, a resolução dessas fixações não estaria na rememoração ou mesmo repetição de um evento traumático mas na vivência de novas possibilidades através do encontro harmonioso com a pessoa do analista. O facilitador de transformação deixa de ser a interpretação e passa a ser o próprio manejo. 
Dentre as características do manejo de um estado regressivo encontramos uma presença asseguradora, presente e disponível. Segundo Balint, o que o paciente atravessando esse fenômeno busca é o reconhecimento, na palavras de Peixoto Junior, "um consentimento explícito para recorrer ao mundo externo, de modo a entrar em contato com seus próprios problemas" (Peixoto Junior, 2013, p. 70). Trata-se de uma experiência na qual, fazendo parte da área da falha básica, os objetos ainda não existem enquanto totais ou mesmo parciais, o analista é, portanto, percebido enquanto substância, e cabe a ele sustentar e transportar o sujeito por um tempo. O papel do analista é o de co-criar com o paciente a atmosfera de harmonia da relação primitiva para que ele possa, a partir disso, desenvolver novas possibilidades de relações objetais. Mais uma vez recorremos ao texto de Peixoto Junior: "Desta forma, o analista realizaria uma das mais importantes tarefas necessárias ao tratamento, que é criar condições nas quais a falha básica possa cicatrizar, até torná-la, quando possível, inativa" (Peixoto Junior, 2013, p.73).

Essas novas possibilidades de relação são o que Balint chamou de new beginning e que aqui estamos chamando de "novo começo". O termo foi utilizado pela primeira vez em 1932, no livro "Primary Love", e foi sendo elaborado ao longo de sua obra. De início Balint teria considerado que esta seria a etapa final de um tratamento mas, mais tarde, afirma que tende a não ser um evento único durante um processo de análise, dificilmente um "novo começo" será suficiente. Ainda assim, podemos compreender porque ele antes afirmara ser o ponto final de uma análise já que o que ele descreve como sendo esse fenômeno muito se assemelha ao que apresenta como sendo o objetivo de um processo analítico. Mas importa sobretudo afirmar que a regressão benigna e a ideia de novo começo afirmam a importância da relação intersubjetiva presente em uma análise. É no encontro sensível com o analista que o analisando pode se despir de suas defesas e padrões para construir, a partir dessa vivência favorável, formas mais livres e flexíveis de se viver e amar.

Antes de seguirmos para uma apresentação da regressão maligna gostaríamos de acrescentar uma última reflexão acerca da benigna. Como já 
vimos, Balint destaca em sua teoria a existência de experiências subjetivas que se manifestam mais pela sensação de uma falha do que a de um conflito. Ou seja, fala em acontecimentos, em marcas psíquicas, que não se materializam nos impasses dos desejos como no sintoma neurótico, mas sim como aprisionamentos em certas formas de relação objetal que se erguem como defesas a falhas mais primitivas. Neste sentido, é bastante evidente que pensamos a regressão benigna e os novos começos como experiências vinculadas à área da falha básica e, assim sendo, a pacientes que diferem daqueles da clínica clássica. Entretanto, parece importante destacar que a regressão não é compreendida por Balint como algo exclusivo de certos tipos de pacientes, o que encontramos em sua teoria é que este seria um processo que nos acompanha em toda a vida mas que, o grande determinante, seria a resposta do analista ao fenômeno. $\mathrm{O}$ nível do aprofundamento nesse estado estaria diretamente vinculado à disponibilidade e ao tato do analista, características para Balint indispensáveis se existe uma verdadeira intenção de transformação no caráter, no funcionamento do paciente.

É no capítulo 22 de seu livro “A Falha Básica” (1968/1992), entitulado "The various forms of therapeutic regression" (As variadas formas de regressão terapêutica), que Balint introduz de forma mais descritiva as diferenças entre as regressões benignas e malignas. Ele começa observando que não o espantaria se seu leitor acreditasse, até então, que ele tomara a regressão como um processo indispensável aos casos difíceis, discordando veemente das advertências de Freud e seguindo rigidamente as descobertas de Ferenczi. Esta afirmativa, entretanto, não condiz com sua percepção da clínica e para desfazer essa ideia ele retorna a vivências clínicas.

Alguns anos atrás (Balint, M., 1952) lidei em alguma medida com o problema daqueles pacientes que, embora passíveis de regressão, não eram capazes de alcançar o estado inequívoco de $\operatorname{arglos}^{63}{ }^{64}$ que é uma pré-condição absolutamente necessária para um novo começo, e cujos tratamentos tiveram de ser interrompidos com um resultado parcial. Embora esses resultados tenham

\footnotetext{
63 Podemos encontrar uma definição para esse estado na seguinte citação: “A substância, o analista, não deve resistir, deve consentir, não deve deixar surgir muita fricção, deve aceitar e suportar o paciente por um tempo, deve se provar mais ou menos indestrutível, não deve insistir na manutenção de barreiras rígidas, mas deve permitir o desenvolvimento de um tipo de mistura entre o paciente e si mesmo." (Balint, 1968/1992, p.145)

${ }^{64}$ Grifo do original
} 
sido bastante aceitáveis, foram aquém daqueles alcançados após um novo começo adequado. (Balint, 1968/1992, p.138)

Indo além, Balint descreve uma situação analítica na qual, ao invés de apresentarem avanços no tratamento após emergirem espontaneamente de um novo começo, os pacientes, ao regredirem e expressarem demandas e desejos primitivos, parecem nunca se satisfazerem. A dinâmica que se constrói é a de uma postura constantemente demandante na qual uma necessidade, quando resolvida, é instantaneamente substituída por outra - sempre tão urgente quanto à anterior. À exemplo, o autor remeta à Anna O., quem, segundo ele, desenvolveu um espiral vicioso. Trataria-se, portanto, de um caso de regressão maligna.

Preocupado em marcar a diferença entre os dois tipos de regressão, Balint (1968/1992) levanta um ponto como crucial: a relação com o mundo externo. Nos casos malignos, as demandas estariam dirigidas ao analista ou ao ambiente enquanto objetos que viabilizariam a gratificação dos desejos. Os objetos são, neste sentido, ativos. Já nos casos benignos o que se espera do ambiente - que, como vimos, é percebido na atmosfera como uma substância mais do que como objetos separados - é um "consentimento de uso" de forma a beneficiar transformações internas. A relação como meio de acessar a si mesmo. Balint propõe, de maneira resumida, que a regressão maligna busca gratificação e a benigna reconhecimento. A fim de aproximarmo-nos do que o autor entende como gratificação, o citamos:

Gratificação por eventos, ou ações, do mundo externo pressupõem um mundo constituído ou por objetos já inteiros, ou por objetos parciais ${ }^{65}$ já bem desenvolvidos, o que significa que a regressão do paciente não pode ter ultrapassado muito o nível narcísico, fálico ou pré-edípico. (Balint, 1968/1992, p.144)

Para ele essa experiência de busca por gratificação de desejos expressos de maneira apaixonada podem ser observados com clareza em crianças nos períodos anteriores à fase adulta do desenvolvimento, sobretudo aquelas que sofrem alguma forma de trauma que veio a levar a distúrbios neuróticos. O psicanalista contemporâneo Christopher Bollas fará uso dessas explorações de Balint para

\footnotetext{
65 Vale especificar que no original encontramos os termos "whole objects", que traduzimos por "objetos totais", e "part-objects", que foi traduzido por "objetos parciais".
} 
pensar um estado que ele chamará de "histeria maligna". Veremos mais sobre no capítulo 4 mas por ora basta dizer que esse tipo de paciente cuja experiência analítica é marcada por uma regressão maligna parece remeter mais a um funcionamento entendido como histérico do que àqueles atendidos por Ferenczi e incluídos na clínica do trauma. Aqui, quando Balint fala em um trauma infantil, estaríamos mais próximos da ideia de Freud de trauma, do que da de Ferenczi, que desenvolve como consequência mecanismos de defesa diferentes daqueles da neurose.

Por fim, apresentamos as principais características elencadas por Balint como representantes de uma regressão maligna. Elas são: a) a atmosfera de $\operatorname{arglos}$, na qual não há desconfiança de nada, não se sustenta e, em reação a seu rápido rompimento, frequentemente surgem sintomas como clinging ("agarrar-se") como forma de proteger-se da ameaça de um novo rompimento; b) o desenvolvimento de uma constante espiral de demandas inatingíveis, o que pode levar a um estado semelhante ao de uma adicção; c) busca por gratificação por uma ação externa; d) desejos, remendos e expectativas são manifestos de forma intensa e pouco silenciosas e; e) presença de sinais de histeria severa e de elementos característicos da relação genital.

Antes de seguirmos parece importante enfatizar que, embora exista, em termos teóricos e práticos, uma marcante diferença entre os dois tipos de regressão, há sempre uma mistura dos dois formatos. Nas palavras de Balint: "É claro que na vida nada é tão simples ou claramente definido. Na maior parte dos casos de regressão terapêutica o que o analista pode ver é uma mistura de todos essas manifestações, com, no todo, uma ou outra característica predominando" (Balint, 1968/1992, p.146).

O que não pode deixar de ser notado é que, independente do tipo de regressão, de sua extensão e intensidade, trata-se de um fenômeno necessariamente intersubjetivo na medida em que se manifesta não enquanto fala mas enquanto atmosfera. Em Balint sobressai a ideia de que a regressão, antes de aconselhada ou evitada, é um acontecimento transferencial e, portanto, o analista está sempre ativo nesse endereçamento mesmo quando o nega. A regressão 
enquanto possibilidade é inevitável, ela enquanto recurso terapêutico é uma possibilidade que se cria a partir de um bom manejo e de um fit possível.

\section{4}

\section{Desenvolvimento emocional primitivo}

Seguimos nosso percurso adentrando agora a teoria do britânico Donald Winnicott. Apresentar algum recorte de sua teoria parece sempre um desafio já que a forma como ele concebe o desenvolvimento humano aparece de forma quase metalinguística em sua construção teórica, ou seja, não linear e interdependente. Assim, para falarmos de sua ideação a respeito dos estados regressivos em análise precisaremos antes apresentar outras noções importantes. Como fizemos com os autores anteriores, exploraremos sobretudo aspectos da relação primordial com o ambiente e a relação analítica.

Quando se sabe pouco sobre Winnicott já se sabe que ele teria dito que um bebê não existe sem sua mãe. A ideia que parecia chocante é amplamante compreendida entre os pensadores relacionais. Em um primeiro momento, o bebê não existe enquanto Eu. Para um observador externo, existem dois indivíduos, o bebê e sua mãe, mas para os participantes dessa relação eles são, em todos os aspectos subjetivos, um só. Foi isso que Winnicott chamou de "unidade dual". Assim sendo, a construção de um Eu individual implica, sobretudo, um processo de separação da mãe. Grande parte de sua teoria se baseará nas qualidades desta separação e nas capacidades que são desenvolvidas neste processo que, de alguma forma, nunca se finda.

Em uma visão que preza pelo corpo biológico Winnicott nos lembra que o bebê humano é, no mundo animal, dos que nasce menos desenvolvido. Ele nasce em um estado que o autor chamará de "dependência absoluta". Essa condição pode ser descrita pela simples ideia de que, à esta altura, o bebê, não havendo uma mãe - um ambiente -, não sobrevive. Isto é, entretanto, evidente quanto à condição biológica do recém-nascido mas Winnicott se aprofunda nas implicações subjetivas desta dependência. Não se trata apenas de um corpo fisiológico que não 
dá conta de si mas de um ego que, enquanto ainda não integrado, depende de um outro para constituir-se enquanto tal.

A ideia da integração do Ego é um dos três processos que Winnicott tomará como pertencentes ao desenvolvimento emocional primitivo. Eles são a integração, a personalização e a realização de objeto, e representam o processo do bebê de se tornar uma unidade psíquica e somática diferenciada dos objetos externos. Ou seja, se tornar um indivíduo separado de seu ambiente. Embora o pensamento winnicottiano não siga uma ordem cronológica e linear e, portanto, os três processos citados acabem se atravessando, podemos distingui-los da seguinte maneira: a integração seria correspondente ao processo no qual, via o empréstimo do ego da mãe, o bebê introjeta a noção de unidade66, podendo então integrar-se enquanto um; a personalização seria como que a alocação desse um em um corpo, ou seja, a compreensão dos limites corpóreos dessa unidade e; a realização de objeto determinaria a capacidade alcançado pelo bebê de, na medida em que se percebe enquanto um, reconhecer também os objetos do mundo em suas unidades distintas.

Devemos chamar atenção para o fato de que esses processos não são em momento algum chamados de "fases" ou "estágios", como costuma acontecer nas teorias do desenvolvimento em Freud e mesmo em Ferenczi. Em Winnicott falamos mais em capacidades a serem desenvolvidas, entendendo que elas nunca se desenvolvem inteiramente - tal coisa não existe - , que elas podem sofrer regressões e podem também serem desenvolvidas mais tarde na vida, sobretudo via a relação analítica. Ou seja, o alcance de um nível satisfatório de integração, por exemplo, não quer dizer que a pessoa não venha a viver momentos de nãointegração ao longo da vida, podendo até desintegrar-se. É, inclusive, a partir da observação das crianças e dos psicóticos que Winnicott percebe a existência dessas capacidades. As nota ao perceber que são elas que se apresentam de

\footnotetext{
${ }^{66}$ Para méritos de esclarecimento, apresentamos uma definição de Winnicott para ego: "Pode-se usar a palavra ego para descrever a parte da personalidade que tende, sob condições favoráveis, a se integrar em uma unidade." (Winnicott, 1962/1996, p.55). Mais à frente no capítulo abordaremos também a ideia de self, mas esta só se torna relevante contando com um estabelecimento anterior do ego.
} 
maneira distinta nessas duas condições humanas. No texto "O desenvolvimento emocional primitivo" ele diz:

O objetivo central deste trabalho é o de apresentar a tese de que o desenvolvimento emocional primitivo do bebê - antes que ele reconheça a si mesmo (e portanto os outros) como a pessoa inteira que ele é (e que os outros são) - é vitalmente importante, e é neste período que serão encontradas as chaves para compreendermos a psicopatologia da psicose." (Winnicott, 1945/2018, p. 222)

Ora, ainda um outro ponto é trazido à luz por essa realização: o que há de comum entre os psicóticos e as crianças? Winnicott dirá que a relação se dá pelo fato dos psicóticos expressarem carências primitivas, como as percebidas nos primeiros anos de vida. Os sintomas psicóticos, que expõem com clareza uma frágil compreensão do $\mathrm{Eu}$ e dos limites entre este e os objetos, aludem aos processos iniciados nos primórdios, na experiência de separação do bebê de sua mãe. É nesse sentido, inclusive, que Winnicott recebe acusações de que sua teoria carregaria uma culpabilização da mãe. A mãe (ou o primeiro cuidador qualquer que assuma essa função subjetiva) de fato é compreendida como pessoa essencial no desenvolvimento do bebê - não há de haver quem discorde disso - mas não devemos usar a teoria winnicottiana de forma simplista e causal. Embora em um primeiro momento o bebê perceba a mãe como seu ambiente, há de se levar em conta todo o ambiente que existe em torno desta dupla. Winnicott não pretendia, em suas conclusões teóricas, localizar a causa dos transtornos psíquicos mas compreender a forma como os sujeitos se constroem enquanto tais e se relacionam com os objetos do mundo. Para ele, esta era uma tarefa de cunho terapêutico já que seu lugar de analista muitas vezes parecia se equiparar ao da mãe.

O lugar da mãe é uma ideia que ele desenvolverá, portanto, com especial cuidado. Muitos de seus textos são dedicados a essa função entendendo que ela é nodal tanto para o desenvolvimento quando para a clínica - seja ela de crianças ou adultos. Para Winnicott quando o bebê vem ao mundo não é só ele que se encontra em uma dependência intensa de sua mãe, também ela se vê nesse nível de vínculo. Ele descreve melhor essa condição através do conceito de "preocupação materna primária", apresentado no texto ${ }^{67}$ que leva o mesmo nome, de 1956 . Nele, o ${ }^{67} \mathrm{D}$, Winnicott. (1956/2018) A Preocupação materna primária. In Da pediatria à psicanálise. 
estado é descrito como uma "condição psiquiátrica", uma manifestação que, não fosse o caso de uma gravidez, seria como uma doença. A mãe manifesta "um estado de retraimento ou de dissociação, ou uma fuga, ou mesmo a um distúrbio num nível mais profundo, como por exemplo um episódio esquizóide, onde um determinadoaspectodapersonalidadetomaopoder temporariamente." (Winnicott, 1956/2018, p.167).

Retomando os aspectos da integração, da personalização e da realização de objeto, podemos usá-los para dizer que a experiência vivida pela mãe, no período que Winnicott enquadra entre os últimos meses de gestação e os primeiros da vida extra-uterina, expressa uma regressão de todas essas capacidades. Ela, na medida em que se vê um só com o bebê, revisita a sua própria experiência primordial de não se conceber enquanto unidade. A preocupação materna primária é, portanto, uma regressão intensa vivida pela mãe a partir da identificação com o bebê e que, no caso dela não se recuperar desse estado, o quadro de fato terá se tornado patológico. Nas palavras de Winnicott:

Gradualmente, esse estado passa a ser o de uma sensibilidade exacerbada durante e principalmente ao final da gravidez; Sua duração é de algumas semanas após o nascimento do bebê; Dificilmente as mães o recordam depois que o ultrapassaram; $\mathrm{Eu}$ daria um passo a mais e diria que a memória das mães a esse respeito tende a ser reprimida. (Winnicott, 1956/2018, p.169)

Essa experiência explicaria o porquê de muitas mulheres abrirem um primeiro surto a partir da maternidade. A chegada de um bebê tão dependente pode explicitar a fragilidade e a não garantia do Eu enquanto unidade coesa e contínua.

Gostaríamos de enfatizar porém que, para Winnicott, embora a experiência de unidade seja compartilhada por mãe e bebê, eles acessam esse estado por meios distintos. Ele diz:

O que nos interessa é a enorme diferença psicológica entre, por um lado, a identificação da mãe com o bebê, e por outro, a dependência do bebê em relação à mãe. A dependência não implica em identificação, pois esta última constitui um fenômeno complexo demais para que o localizemos nos primeiros estágios da vida do bebê68. (Winnicott, 1956/2018, p.171)

68 Grifo do original 
Logo, as implicações desse encontro são muito diferentes. Enquanto a mãe, quem já idealmente realizou suas capacidades emocionais, pode a partir de um acesso a sua própria experiência primitiva identificar-se com o bebê ao ponto de compreender de forma extremamente sensível suas necessidades e, assim, emprestar seu ego ao infante, o bebê depende em absoluto dessa mãe para construir e acreditar em sua possibilidade de existência. Ou seja, se a mãe experiencia nesse encontro a ameaça de não recuperar-se, não retornar ao seu Ego já mais independente, o bebê, por sua vez, encontra nessa vivência a possibilidade de desenvolver sua potência inata de vida, sua tendência a um desenvolvimento saudável.

Nesse sentido, Winnicott é um autor extremamente otimista, já que dirá que todos nascem com um potencial para o desenvolvimento, cabendo ao ambiente apenas facilitá-lo. É dessa ideia que decorre o conceito de "ambiente suficientemente bom". Se por vezes sua teoria parece culpabilizar a mãe, é nesse aspecto que encontramos uma "libertação". A mãe, embora essencial para o desenvolvimento, não precisa ser perfeita, basta sua suficiência. A suficiência pode aqui ser melhor entendida se somamos as ideias de holding e handling. Esses conceitos falam de um manejo e um sustento que, além do atendimento das necessidades, representam um cuidado mais sensível demandado pelo bebê na primeira etapa da vida. Novamente, eles retomam os processos de integração e personalização na medida em que representam um toque, um olhar, uma atenção que auxiliam a dar contorno ao psiquismo e ao corpo do bebê.

Diferentemente de Freud, que focou em pensar as satisfações libidinais no desenvolvimento infantil, Winnicott enfatiza as necessidades e a qualidade de seus atendimentos. Ele fala por exemplo do mamar não só como ato erogenizado mas como uma resolução de necessidade e que pode ser de maior benefício para o desenvolvimento do bebê se inclui, por exemplo, o olhar da mãe que enxerga e reconhece seu bebê. Esse olhar o ajudaria a afirmar sua existência e, o ritmo da sucção, bem como o tempo entre as amamentações e sobretudo da ausência da mãe, a construir uma confiança na continuidade do ser. 
Se falamos em uma dependência absoluta em um primeiro momento de vida, na medida em que a mãe suficientemente boa pode ir saindo do seu estado de preocupação materna primária e, aos poucos, gradualmente - isso é de suma importância -, retornar ao seu ego e às suas outras funções, o bebê vai podendo se separar e caminhar no sentido de uma dependência relativa. Essa nova condição é desenvolvida se o bebê teve um ambiente suficientemente bom, podendo então confiar o suficiente no entorno para se aventurar no encontro com a realidade externa. A essa vivência da dependência relativa Winnicott atribui os processos criativos. É nesse processo que o bebê começa a criar o mundo na medida em que começa a se conceber como unidade separada dentro dele.

A concepção de uma dependência relativa pode nos auxiliar a compreender o aspecto paradoxal da teoria winnicottiana. Em muitos de seus conceitos devemos aceitar uma sobreposição de ideias que não pretendem ser resolvidas. Nesse estado, por exemplo, falamos que o bebê está e não está separado da mãe/ambiente, trata-se de uma interdependência entre sujeito e ambiente na qual ambos se criam mutuamente, havendo uma interseção entre os dois. Essa interseção é o que melhor representa o período da dependência relativa. Esse tipo de ideia irá se repetir ao longo de seu desenvolvimento teórico, a notamos, por exemplo, nos conceitos de espaço potencial, no brincar, na capacidade de estar só e nos objetos e fenômenos transicionais.

De maneira geral, podemos dizer que todos esses exemplos abordam essa transição de um bebê que é absolutamente dependente de sua mãe, ao ponto de apenas existir com sua presença, para um que vive "rumo à independência", para Winnicott o maior nível de independência que se pode alcançar. Sobre isso ele diz: "O indivíduo normal não se torna isolado, mas se torna relacionado ao ambiente de modo que se pode dizer serem o indivíduo e o ambiente interdependentes.". (Winnicott, 1963b/1996, p.80). A transição entre o estado primeiro (da dependência absoluta) e o último (rumo à independência) é, paradoxalmente, a sobreposição dos dois.

O que chamamos de dependência relativa pode ser ilustrado por um bebê que já começa a se perceber enquanto um mas que ainda sente, nas ausências 
excessivas da mãe uma ansiedade de aniquilamento marcante. É um momento intermediário entre a concepção apenas subjetiva da própria existência e a percepção objetiva dos objetos do mundo. Nas palavras de Winnicott: "A região intermediária à qual estou me referindo é aquela que é liberada para o bebê entre a criatividade primária e a percepção objetiva baseada no teste da realidade." (Winnicott, 1951/2018, p.327). À exemplo temos o objeto transicional que é, simultaneamente, a primeira posse não-eu e parte do eu. É um objeto que já existe como parte do mundo mas que é também criado pelo bebê.

O que temos é que seria apenas após a exploração dessa zona transicional, que deve ser vivida de forma suficientemente boa, que o infante pode alcançar vivências características de uma vida mais independente. A independência pode ser caracterizada pela possibilidade de se perceber enquanto unidade distinta dos outros objetos do mundo com os quais se relaciona e que, mesmo em momentos de não-integração, que não deixarão de existir, é capaz de retornar a si mesmo. Trata-se de um ego suficientemente formado ao ponto de não mais depender completamente dos outros para assegurar sua existência. As vivências primitivas foram realizadas de tal forma que o indivíduo já pode confiar que, mesmo diante ameaças do ambiente, isso não será suficiente para descontinuar seu ser.

É claro que todos os pontos apresentados podem ser muito aprofundados mas acreditamos ter abordado pontos que nos serão essenciais para avançarmos. Eles seriam: a noção de que o bebê, em um primeiro momento, não existe nem fisicamente nem subjetivamente sem sua mãe; a compreensão de que o ego é algo a ser construído e desenvolvido a partir do encontro com o ambiente e; o entendimento de que, em Winnicott, o desenvolvimento não será percebido como algo linear e unilateral, mas sim um processo contínuo que atravessa a vida do sujeito. 


\section{5}

\section{O ego e o self}

Há ainda um importante aspecto sobre o desenvolvimento que até agora deixamos de abordar: o desenvolvimento do self. Este conceito, característico da psicanálise britânica, é descrito por Winnicott como o "o núcleo da personalidade." (Winnicott, 1962/1996, p.56). Ao longo de sua obra entendemos que o self pode ser entendido também como o núcleo do ego, uma forma de ser que se desenvolve a partir deste contorno de ego ${ }^{69}$.

Colocando sempre em primeiro plano a relação do sujeito com o ambiente Winnicott entenderá que a qualidade predominante do self irá variar em função da possibilidade de se confiar no ambiente. Sendo ele suficientemente bom, um "verdadeiro self" ganhará espaço, não o sendo, um "falso self" se erguerá enquanto defesa. Defesa do que? Defesa aqui pode ser entendido enquanto barreira protetora do verdadeiro self que, mesmo quando pouco desenvolvido, nunca deixa de existir enquanto potência. Winnicott diz: "Da evolução deste caso me foi fácil verificar a natureza defensiva do falso self. Sua função defensiva é a de ocultar e proteger o self verdadeiro, o que quer que este possa ser." (Winnicott, 1960/1996, p.130).

A relação entre o verdadeiro self e a confiabilidade no ambiente se apresenta na medida em que o compreendemos enquanto potência criativa e espontânea. É apenas na presença de um ambiente seguro que o bebê pode agir de maneira espontânea. A mãe suficientemente boa, da qual já falamos, deve garantir ao infante a possibilidade de experimentar seu ser sem que ameaças excessivas sejam percebidas. Segundo Winnicott (1960/1996) é apenas a partir desse tipo de vivência que o sujeito pode se desenvolver no sentido de perceber e perseguir seus próprios desejos, caso contrário, ele se portará de maneira defensiva, respondendo mais às demandas do ambiente do que às suas próprias.

\footnotetext{
69 Importante enfatizar que não queremos com isso dizer que na ausência de um ego mais integrado não há self. Quando associamos no tópico anterior estados psicóticos ao fenômeno da desintegração do ego, isso não implica na ausência de um self mas faz com que este se manifeste em qualidades diferentes. Se estamos falando no self como uma forma singular de ser, é evidente que o mesmo se aplica ao psicótico, a distinção reside no fato de que nesses casos essa forma de ser estará menos contornada enquanto unidade.
} 
Essa relação entre o verdadeiro e o falso self não é, entretanto, binária, trata-se mais de uma questão de distribuição do que de perpetuação. No texto "Distorção do ego em termos de falso e verdadeiro self" (1960/1996) Winnicott descreve diferentes níveis possíveis de domínio do falso self sobre o verdadeiro, expondo como esta pode variar de uma situação extrema, na qual "o falso self se implanta como real e é isso que os observadores tendem a pensar que é a pessoa real." (Winnicott, 1960/1996, p.130), a uma intermediária, "o falso self tem como interesse principal a procura das condições que tornem possível ao self verdadeiro emergir." (Winnicott, 1960/1996, p.131), a ainda uma terceira, que seria a situação representativa da normalidade, "falso self é representado pela organização integral da atitude social polida e amável" (Winnicott, 1960/1996, p.131). A imagem que fica é a de uma balança na qual falso e verdadeiro self se relacionam entre si em decorrência das exigências do ambiente e das possibilidades daquele ego.

A partir desses extratos já é possível perceber que o falso self não deve, de forma alguma, ser percebido como um vilão a ser eliminado. Na sua qualidade de defesa ele serve também para viabilizar a vida social. Se fossemos todos inexoravelmente espontâneos a organização em comunidade se tornaria impossível. Porém fica evidente também que, caso excessivamente desenvolvido, a defesa toma conta da experiência subjetiva da pessoa, impedindo que ela mesma se reconheça. Isso se torna evidente em diversos casos clínicos, nos quais falas como "me sinto como um personagem" e "não me sinto dono de minha própria vida" se tornam recorrentes, apontando para o fosso que se instala entre o $\operatorname{ser}^{70} \mathrm{e} \mathrm{o}$ mundo.

Buscando evitar o risco de deixar a compreensão do verdadeiro self de forma metafísica ou árida devemos associá-lo ao que Winnicott chamou de "gesto espontâneo". Para isso, extraímos uma passagem do texto de 1960:

\footnotetext{
${ }^{70} \mathrm{O}$ verbo "ser" será de grande importância na obra winnicottiana. Do original "going on being", que podemos traduzir por "continuar a ser", compreendemos a experiência de se ver enquanto unidade integra e contínua, com possibilidades para existir para além do momento presente das sensações. No último capítulo usaremos este conceito para pensar a relação do sujeito contemporâneo com o tempo. Ainda na obra de Winnicott, o verbo "ser" também é utilizado para falar de uma qualidade feminina da existência que estaria em oposição ao "fazer", potência masculina. No uso presente do verbo podemos arriscar dizer que caberia articulá-lo aos dois aspectos citados da teoria winnicottiana visto que o que desejamos salientar é a possibilidade de existir continuamente com uma genuína experiência de ser si mesmo, presente nas duas concepções de "ser" citadas.
} 
Ao pesquisar a etiologia do falso self, estamos examinando o estágio das primeiras relações objetais. Nesse estágio, o lactente está não-integrado na maior parte do tempo, e nunca completamente integrado; a coesão dos vários elementos sensório-motores resulta do fato de que a mãe envolve o lactente, às vezes fisicamente, e de modo contínuo simbolicamente. Periodicamente um gesto do lactente expressa um impulso espontâneo; a fonte do gesto é o self verdadeiro, e esse gesto indica a existência de um self verdadeiro em potencial. (Winnicott, 1960/1996, p.132/3).

O gesto espontâneo não é, portanto, um grande momento ou feito do bebê mas seus pequenos atos de independência, de descoberta - não só psíquica mas também corporal -, que devem ser reconhecidos e atribuídos a ele. Eles estão, em parte, dentre as primeiras ações criativas do bebê, às quais Winnicott atribui o lugar de saúde. A mãe que não é capaz de reconhecer esses gestos pode acabar por atropelá-los, os substituindo pelos seus próprios e gerando no lactente uma sensação de submissão - "Essa submissão por parte do lactente é o estágio inicial do falso self, e resulta da inabilidade da mãe de sentir as necessidades do lactente." (Winnicott, 1960/1996, p.133).

Novamente somos deparados com a sobreposição entre o "ser" da mãe e o do bebê. Parece que a todo momento do que passou a ser compreendido como a teoria winnicottiana estamos lidando com os equilíbrios e desequilíbrios desta primeira relação a qual, e por isso ainda mais relevante, a dupla analista paciente será análoga. Mas nesse ponto devemos destacar a sutileza dos processos que vêm sendo descritos. Embora estejamos ilustrando a teoria com exemplos que pretendem exprimir os conceitos em experiências palpáveis, há algo da ordem do minucioso do subjetivo que aparecerá menos de forma passível de verbalização e mais apenas na relação.

Como vimos, o processo de desenvolvimento do self está diretamente articulado à confiança no ambiente na medida em que este ditará as defesas que serão desenvolvidas e predominantes. Se as ameaças à unidade do ego acontecem em um momento precoce o sujeito só pode responder por processos de cisão e estes, por sua vez, dificultam essa possibilidade de integrar-se e perceber-se enquanto ser contínuo. Já vimos como é neste contexto que o falso self tende a predominar na medida em que se ergue como barreira protetora do self espontâneo que não encontra um meio seguro para expressar-se. Assim, 
retomando a ideia de gesto espontâneo e da presença faltante ou excessiva da mãe, no ambiente analítico espera-se sobretudo, que o analista possa prover uma atmosfera de segurança na qual a espontaneidade encontrará espaço para desenvolvimento.

No próximo tópico a ser abordado veremos como esta postura de acolhimento do analista é o que viabiliza movimentos de regressão ao estado da dependência absoluta o que, no entendimento de Winnicott, daria ao sujeito uma nova oportunidade de desenvolvimento de capacidades que ficaram subdesenvolvidas. Estas capacidades incluem tanto as tarefas do ego de integração, personalização e realização de objeto, como as manifestações do verdadeiro self. Ou seja, a partir do provimento de um ambiente facilitador, o sujeito tende a se desenvolver no sentido da saúde, no sentido de um criar da própria vida.

\section{6}

\section{Regressões em análise: a função materna do analista}

A apresentação da teoria winnicottiana que fizemos até aqui nos será essencial para compreender o que o autor britânico descreveu como uma regressão em análise. Acreditamos que já tenha ficado minimamente claro o porquê dela poder ser considerada benéfica em sua teoria mas cabe agora descrevê-la de maneira mais cuidadosa pontuando as excepcionalidades e também as limitações acerca do conceito na obra de Winnicott. Importante afirmarmos em primeiro lugar que quando falamos em regressão neste autor trata-se sempre de um processo de regressão à dependência. Ou seja, tomamos como base a sua teoria do desenvolvimento que percebe o caminho do sujeito a partir do nível e da qualidade de interação com o ambiente para pensar a regressão como um retorno a formas mais iniciais dessa relação. 
Uma diferença precisa ser feita e Winnicott a faz em seu trabalho apresentado pela primeira vez em Paris em 1954, "Retraimento e regressão71". Nele, o autor discute os dois tipos de acontecimentos aludidos no título. O primeiro diria respeito um momento da análise, da sessão, na qual se perceberia um recolhimento repentino; já o segundo falaria em um processo mais do que apenas um momento e um processo este que não é solitário, ao invés de se afastar do mundo externo convoca o analista a uma viagem à dois. Winnicott descreve essa diferença no início do texto da seguinte maneira:

Por retraimento, no presente trabalho, refiro-me a um desligamento momentário da relação atenta com a realidade externa, esse desligamento sendo por vezes da natureza de um breve adormecimento. Por regressão refiro-me a uma regressão à dependência e não especificamente uma regressão em termos de zonas erógenas. (Winnicott, 1954b/2018, p.255)

Embora a ideia de retraimento vá ser menos explorada ela é apresentada como uma experiência que, embora não seja equivalente a uma regressão, pode ser entendida como um prelúdio da mesma. Winnicott (1954b/2018) dirá que, se estes momentos são bem manejados eles podem levar ao desenvolvimento de uma confiança no ambiente que permitirá ao analisado uma regressão à dependência. Esta regressão não é, porém, algo que deve acontecer nem que irá acontecer em toda análise mas um processo que, se o analista puder ir de encontro ao analisando, poderá servir para manejar elementos da subjetividade que não poderiam aparecer de outra forma. É neste sentido que ela aparece para Winnicott como um processo relevante para a teoria psicanalítica. A este fenômeno é atribuída a possibilidade de atualização de falhas ambientais primitivas.

Mas do que falamos quando trazemos à tona elementos que são exclusivos das vivências regressivas? O entendimento de Winnicott, que se assemelha ao que já apresentamos via as teorias de Ferenczi e Balint, é o de que certas experiências primitivas não só deixam marcas no desenvolvimento como deixam marcas que são impassíveis de verbalização e que aparecem de forma desorganizada por não

\footnotetext{
${ }^{71}$ Tradução de "Withdrawal and Regression". A palavra withdrawal é uma de difícil tradução. No inglês ela descreve necessariamente um processo de retirada de algo, a ausência de algo que antes estava presente. Se referindo a um processo subjetivo, optamos pela tradução "retraimento" primeiro por ser aquela utilizada por tradutores da obra de Winnicott mas também por entender que a opção "retirada" não seria compatível com a experiência subjetiva que mais se assemelha a um mecanismo de recolhimento de algo do que de ausência propriamente dita.
} 
estarem inteiramente integradas ao ego. Levando em conta o resto de sua teoria, devemos atentar-nos ao fato de que a maior questão aqui é a da relação dessas falhas primitivas com a constituição egóica e do self. A questão da linguagem tem, na teoria winnicottiana, menos destaque do que naquelas aqui antes apresentadas.

Ainda no texto de 1954 somos deparados com algumas vinhetas clínicas que podem nos servir de ilustração do papel do analista que se encontra este tipo de situação analítica. Winnicott relata um episódio no qual o paciente teria de repente se encolhido todo no sofá - a imagem que vem ao ler é a de uma pessoa recolhida em posição fetal - e, diante tal acontecimento, o analista oferece uma interpretação que articula esse movimento do sujeito, que pode ser entendido como um momento de retraimento, com sua descrição sobre como se sentia em termos corporais. $\mathrm{O}$ autor diz que, embora tenha feito uma interpretação, esta não tinha o cunho freudiano de intervir em uma associação pretendendo trazer à tona material até então inconsciente. A interpretação oferecida tinha como objetivo acolher o paciente ao expressar uma compreensão profunda sobre sua sensação até então impassível de elaboração não por se tratar de material recalcado mas sim material não integrado. Ele faz a seguinte afirmativa sobre a interpretação:

Eu tinha me provado capaz de prover um meio apropriado no momento de seu retraimento. Ao que parece, por eu ter imediatamente dado um meio que contornasse o seu estado de retraimento eu pude converter seu retraimento em uma regressão, e então viabilizado que ele usasse essa experiência de forma construtiva. (Winnicott, 1954b/2018, p. 257) ${ }^{72}$

O que Winnicott segue por desenvolver é que se o analista pode lidar com esses momentos de retraimento com o tipo de manejo adequado, ou seja, expressando uma confiabilidade e sensibilidade do setting, o paciente entenderá, inconscientemente, que o analista pode cuidar dele. Como consequência, esses breves momentos de retraimento poderão se tornar períodos de regressão à dependência nos quais, seguindo o paradigma da mãe suficiente boa, o analista deve se adaptar às necessidades - por mais delicadas e sutis que sejam - do paciente. Segundo o teórico, o benefício de uma regressão em oposição a um

${ }^{72}$ Grifo do original 
breve retraimento seria porque aquela carrega uma oportunidade de atualização de falhas primitivas enquanto esta não gera transformação.

Seguindo essa linha de raciocínio podemos pensar que a concepção de regressão de Winnicott guarda semelhança com a noção de novo começo vista em Balint. Entretanto, tal afirmação não pode ser feita e muito menos de maneira leviana. Como vimos, para o húngaro o novo começo, bem como a regressão, estão necessariamente referidos às formas de relação de objeto, às qualidades da forma de ir de encontro aos objetos do mundo. Já em Winnicott é da nossa compreensão que a questão está mais voltada para a forma como o sujeito pode se perceber enquanto eu integrado em relação ao meio e o quanto pode se expressar de maneira espontânea. As variâncias de alguma forma definem as diferentes percepções do que é saúde e o que é o objetivo de uma análise.

Voltemos à descrição da regressão à dependência em Winnicott. Novamente, entramos em território distinto da técnica freudiana. Embora Winnicott se ocupe pouco desta articulação, em um de seus textos mais importante sobre a regressão, "Aspectos clínicos e metapsicológicos da regressão no contexto analítico" (1954a/2018), ele algumas vezes faz referência ao pai da psicanálise. Isso, por si só, pode acentuar a controvérsia inerente a este fenômeno clínico. O que Winnicott enfatiza é que neste tipo de acontecimento clínico a postura do analista e o que a atmosfera analítica deve prover se afasta enormemente da ideia de frustração de Freud. A sugestão do britânico vai quase no sentido oposto dizendo que, não só não se deve trabalhar no registro da abstinência como se deve, por um tempo, dar lugar à dependência do paciente em relação ao analista e atender cautelosamente às suas necessidades.

A defesa de Winnicott vai no sentido de afirmar que a técnica clássica opera em um registro no qual os pacientes se encontram já em um estado do desenvolvimento no qual podem contar com um ego integrado e com possibilidade de continuidade enquanto a clínica de pacientes regredidos trabalha com sujeitos que, por uma insuficiência do primeiro ambiente, acabaram por terem certas capacidades congeladas e defesas primitivas erguidas. Diante este tipo de paciente, uma interpretação só seria eficiente quando na intenção de agir 
como holding. A técnica tradicional, que teria como principal objetivo e como solução dos sintomas neuróticos a rememoração e a elaboração de material antes inconsciente, deve nesses casos ser substituída por uma condução que tem como prioridade o prover de um ambiente seguro - suficientemente bom.

Nos parece interessante levar aqui em conta a seguinte afirmativa de Winnicott no que diz respeito a técnica e a teoria sobre a clínica: "eu agrupo casos de acordo com o equipamento técnico que eles exigem do analista" (Winnicott, 1954a/2018, p.278). Essa ideia nos serve para entender que quando falamos em pacientes regredidos não devemos entender que trata-se de um sintoma nem muito menos de um sintoma comum a todos esses pacientes, mas sim de uma "categoria" que pode ser construída na medida em que exige do analista um funcionamento específico que não teria aparecido na psicanálise clássica. No mesmo texto Winnicott fala em como cada paciente tem seu próprio ritmo e percurso analítico e como este é sempre ditado pelo analisando e não pelo analista; foi ao se deixar ser guiado que o pediatra se deparou com um tipo de sofrimento além da neurose e pôde perceber nesses casos importava mais o manejo e o setting do que uma economia pulsional. Sobre o que ele coloca como um terceiro grupo de pacientes ele diz:

Em um terceiro grupo localizo todos aqueles pacientes cuja análise deverá lidar com os estados iniciais do desenvolvimento emocional, anteriores ao estabelecimento de uma personalidade enquanto entidade, anteriores à aquisição do estado das unidades espaço-tempo. A estrutura pessoal ainda não é seguramente estabelecida. Em relação a este terceiro grupo, a ênfase = certamente recai sobre o manejo, e por vezes durante longos períodos o trabalho analítico ordinário terá que ser deixado de lado com esses pacientes, o manejo se tornando a totalidade do trabalho. (Winnicott, 1954a/2018, p.279)

Esses pacientes, se tentamos definí-los por aquilo que os une, poderiam ser, antes de tudo, descritos como sujeitos que sofrem em função não de conflitos pulsionais mas de falhas primitivas que afetaram a consolidação, integração e continuidade de seu ser. Clinicamente isso poderia se manifestar de diversas formas - verbalizadas ou não -, mas que necessariamente convocariam o analista a um lugar de cuidado mais fino. Somos obrigados a mais uma vez levarmos em conta o fator contratransferencial. As demandas do analisando não são explicitamente direcionadas ao analista mas devem ser identificadas pelo mesmo. 
$\mathrm{O}$ analista deve perceber e atender as necessidades do paciente com o objetivo de preencher as lacunas da experiência primitiva em um ambiente que foi incapaz de se adaptar ao bebê. $\mathrm{O}$ analista é quem deve agora se adaptar. Nesse sentido podemos perceber como, na teoria winnicottiana, o analista pode ser colocado no lugar de objeto.

Em termos técnicos os cuidados que devem aqui ser tomados se assemelham aos já aludidos ao falarmos da relação mãe-bebê. Na medida em que o analista do paciente regredido está incluído em uma relação de dependência absoluta tal qual esta primeira, sua postura deve ser provedora e silenciosa. Neste momento do encontro qualquer ação que seja excessivamente dotada de sentido e principalmente de uma personalidade própria poderá levar a uma vivência intrusiva e atropelar o desenvolvimento do ser do paciente. Aqui volta a ser relevante a ideia de verdadeiro self. $\mathrm{O}$ analista que vai de encontro ao paciente regredido deve estar atento aos seus movimentos mais finos na direção da própria espontaneidade, é no ambiente seguro da análise e no reconhecimento e na permissividade do analista que o analisando poderá encontrar lugar para baixar suas defesas e desenvolver-se à sua própria maneira, sem precisar se adaptar a um ambiente não acolhedor.

O falso self que como vimos, se ergue como defesa de um ambiente primitivo que falhou com as necessidades do indivíduo, é o exemplo mais abordado por Winnicott ao falar da regressão. O que ele pontua é que essa defesa é também uma medida de esperança já que se constitui para proteger os aspectos mais preciosos da singularidade de cada um na expectativa de que mais tarde possa haver possibilidade para seu desenvolvimento. Assim, pensando em termos do desenvolvimento e organização do ego - que necessariamente envolve o funcionamento do self - Winnicott (1954a/2018) diz que o fenômeno da regressão deve ser pensado como um processo de cura e de confiança inconsciente no potencial do ambiente. Ele diz: "É como se houvesse uma expectativa de que melhores condições possam surgir justificando uma regressão e oferecendo uma nova chance para avanço no desenvolvimento, que foi inicialmente 
impossibilitado ou dificultado por falhas ambientais" (Winnicott, 1954a/2018, p. 281).

A todo momento que falamos de regressão em Winnicott estamos inevitavelmente incluindo algumas concepções: um destaque no desenvolvimento do ego; uma maior relevância do funcionamento do ambiente do que do indivíduo no início da vida; a tendência ao desenvolvimento de defesas pessoais; e a possibilidade de retorno a esses pontos de fixação. Nesse sentido o próprio autor faz questão de ressaltar que a regressão da qual fala é inteiramente diferente daquela pensada por Freud como retorno a pontos de fixação no desenvolvimento sexual do sujeito. Se fala em pontos de fixação é em termos de congelamento da situação de falha ambiental primitiva, que retorna na regressão como manifestação de uma dependência não superada em função de um ambiente que não teve condições de resolvê-la. Ele difere ainda a regressão em análise dos processos patológicos de retraimento (fenômeno ao qual já aludimos) e das cisões. Embora todos sejam exemplos de mecanismos de defesa, no caso da regressão à dependência há um fator diferencial que é a esperança de uma nova oportunidade, uma chance para o descongelamento da situação primitiva, e de um ambiente que, mesmo tardiamente, possa se adaptar ao indivíduo (Winnicott, 1954a/2018, p. 283).

Por fim, devemos endereçar com maior cuidado a função do analista que se depara com essa situação. Pelo o que já descrevemos podemos afirmar que o setting analítico por vezes irá servir como este ambiente que o indivíduo marcado pelas falhas primitivas tinha a esperança inconsciente de encontrar. Nesses casos o papel primordial do ambiente é o de se adaptar em uma tentativa de a atualizar a situação anterior na qual fora o indivíduo quem se adaptara ao ambiente e, para tanto, deixara de desenvolver seu verdadeiro self em pró de uma defesa necessária. $\mathrm{O}$ analista deve, em maior ou menor intensidade, agir como a mãe suficientemente boa. Em alguns casos será necessária uma maternagem até mesmo física mas o que sobressai é a ideia de um analista sensível e paciente. A passividade, inerente ao lugar do paciente - mesmo à palavra -, recai sobre o analista. 
No texto de 1963, "Comunicação e falta de comunicação levando ao estudo de certos opostos", Winnicott afirma que na relação com pacientes regredidos o analista se encontra na posição de objeto subjetivo; isto porque, na medida em que houve uma regressão à dependência o paciente experiencia um estado anterior à integração do ego, não reconhecendo, senão de forma subjetivamente concebida, os outros objetos do mundo. Portanto, cabe ao analista um trabalho silencioso, que mais suporta do que interfere na condição do paciente. Ele deve saber esperar ser objetivamente percebido pelo paciente para então intervir, caso contrário, seu ego, ao invés de servir de amparo, pode vir a ser intrusivo. Bonaminio (2011) nos diz algo indispensável sobre a interpretação:

Virtualmente, no mesmo momento em que o analista decide fazer um comentário para interpretar, ele está interrompendo a continuidade do processo que ocorre na privacidade do paciente (livre associação), uma vez que introduz seu ponto de vista no campo analítico. Assim, a interpretação é sempre separativa e intrinsicamente um veículo de alteridade $^{73}$. (Bonaminio, 2011, p. 164)

Mas para não corrermos o risco de um equívoco, vale explicitar que não se trata de uma completa inviabilização da interpretação enquanto recurso, mas de um cuidado fino que, à maneira do pensamento paradoxal de Winnicott, faça das contribuições do analista sempre do paciente. O material que surge no campo deve ser de criação do paciente ainda que o analista assuma o papel de representá-lo por ele. É o que Winnicott considera em 1968 ao dizer que "o analista reflete de volta o que o paciente comunicou" (Winnicott, 1968/1996, p.209).

Como vimos até aqui a clínica winnicottiana, assim como a de Balint e Ferenczi, opta por expor outras camadas do sujeito que aparecem na medida em que o analista se dispõe a um outro tipo de escuta. É salientando sobretudo o manejo como técnica que acessamos formas mais primitivas de funcionamento que declaram a inevitável participação do ambiente no desenvolvimento. Winnicott (1954a/2018) nos lembra, entretanto, que todas essas considerações sobre a regressão e sobre a importância do holding no setting analítico não desconsideram a técnica freudiana, que trabalho no registro da castração e do

${ }^{73}$ Grifo do original 
desenvolvimento individual sexual. Esses aspectos da clínica clássica não devem ser descartados mas deixados de lado até que sejam passíveis de compreensão pelo sujeito. A denúncia desses autores que consideram a intersubjetividade vai no sentido de afirmar que há na relação entre analista e paciente uma possibilidade que diz mais respeito o campo que ali se estabelece do que a comunicação verbal estabelecida. Esta segunda é chave fundamental para a clínica psicanalítica mas com certos tipos de pacientes que expressam defesas distintas das neuróticas o trabalho terá que levar em consideração também outros tipos de recursos técnicos.

Tendo percorrido esses três autores que se voltam para a importância do ambiente, iremos agora usá-los como base para pensar a clínica contemporânea. Não poderíamos pensar os estados regredidos na atualidade sem as contribuições aqui explicitadas. Seguimos então com a compreensão de que a regressão em análise é, inevitavelmente, um processo que toma o analista como uma posição a ser pensada na relação. Nessas circunstâncias a postura observadora e intervencionista passa a ser insuficiente e um cuidado mais sensível e disponível passa a ser necessário para que a regressão possa se concretizar como oportunidade de uma nova organização subjetiva. A regressão enquanto fenômeno terapêutico está, para Ferenczi, Balint e Winnicott, intrinsicamente ligada à relação transferencial e contratransferencial. Veremos no próximo capítulo como essas afirmativas são vividas clinicamente. 


\section{5. \\ Clínica contemporânea: o que se vive além da palavra}

Nos capítulos anteriores percorremos autores de diferentes momentos da história da psicanálise, ainda assim, todos falam de tempos já ultrapassados. Começamos com o pai da psicanálise, apresentando a origem da ideia de inconsciente e leituras do aparelho psíquico essenciais até hoje, e seguimos com autores que representam a base de uma linha clínica que se propõe a pensar o sujeito em suas relações com o ambiente e seus objetos, colocando em destaque as relações intersubjetivas em detrimento das intrapsíquicas. Esse percurso foi adotado por considerarmos que as contribuições de Ferenczi, Winnicott e Balint são uma chave de leitura enriquecedora para se pensar a clínica contemporânea.

Um ponto que merece ser destacado como meio de comparação entre esses três autores e Freud é o tipo de paciente por eles recebidos. Com o cuidado de não reduzirmos pacientes a uma classificação simplista podemos iluminar o fato de que Freud, na condição de percursor de uma terapêutica que tinha como objetivo primeiro desvendar e curar o fenômeno histérico, manteve seu foco no sintoma neurótico. Podemos entender a neurose - a partir das descobertas de Freud - como o funcionamento psíquico cujo principal mecanismo é o recalque e, na medida em que compreendemos que foi essa a defesa que serviu como balizadora da compreensão freudiana do aparelho psíquico, fica mais acessível a ideia de que sua teoria deu conta sobretudo deste tipo de funcionamento. Este, contudo, logo se mostrou não ser o único, deixando Freud muitas vezes em busca de um mecanismo "análogo".

Como já vimos no terceiro capítulo, Ferenczi, com um objetivo sempre mais terapêutico do que científico, atendeu uma diferente gama de pacientes. Diferente justamente porque na relação clínica se apresentavam de maneira distinta dos pacientes freudianos. Foi nesse sentido que o húngaro acabou por descrever outras formas de subjetividades. A partir de uma postura sensível pôde perceber que a técnica clássica, baseada sobretudo nos princípios da associação livre enquanto regra fundamental e da interpretação como principal forma de intervenção, em certos casos se mostrava insuficiente, exigindo do analista uma 
abordagem de maior experimentação. A partir do enfrentamento dos impasses clínicos Ferenczi descreveu novas possibilidades, o que fez dele um autor divisor de águas na história da psicanálise.

Nesse seu comportamento explorador identificamos a abertura para uma psicanálise que, se distanciando de uma lógica que prioriza a interioridade e o domínio da mesma, extrapola aquilo que há de mais importante e que pode manter esta prática atual: a clínica. A psicanálise deixa de ser o campo de saber da neurose para se perpetuar enquanto prática que acompanha os "campos de força que afetam" (Borges, 2019) o sujeito, e nesse sentido escapa do lugar de antiguidade. Assim, é com esse espírito que buscamos neste último capítulo esboçar aspectos que nos parecem chave para se pensar a clínica e o sujeito contemporâneo. O faremos a partir dos conceitos que foram até aqui exaltados atentando-nos sobretudo à relação transferencial e contra-transferencial e aos fenômenos regressivos. O que ficará evidente é que estes aspectos foram destacados justamente por convocarem discussões pertinentes para se pensar a clínica hoje e a clínica enquanto saber dinâmico e inconstante. Com a intenção de dar vida ao trabalho contaremos com a ilustração de situações clínicas, tanto nossas quanto de autores selecionados.

\section{1 \\ O lugar do analista, do paciente e da psicanálise}

Encontramos uma única forma de pensar a psicanálise na atualidade e numa constante atualidade: em seu devir, isto é, a clínica. Esta, por sua vez, pode ser definida pelo encontro entre dois sujeitos, dos quais um ocupa a função de analisando e o outro de analista. O enquadre - seja no consultório, em uma plataforma online, uma instituição ou na rua - é constituído por essa relação. Esta relação não é, entretanto, estática, mas é alterada segundo as possibilidades determinadas pelo metódo psicanalítico. De alguma forma podemos dizer que caímos, à maneira de Winnicott, em um paradoxo. A psicanálise define o encontro analítico mas é o encontro que ativamente constrói uma psicanálise. A partir desse paradoxo, portanto, se cria. Criam-se sujeitos e se cria uma prática intersubjetiva. 
Tal qual a psicanálise, também o sujeito só existe em seu devir. O inconsciente trabalha de forma atemporal e dinâmica (Freud, 1915c/2010), e na medida em que se vê em constante fronteira entre psique e soma, dentro e fora, se atualiza incessantemente de forma a nunca ser apreendido. Dessa compreensão surge uma psicanálise que pode existir em qualquer tempo porque pode e precisa acompanhar o sujeito, e não um suposto saber pré-estabelecido e inerte. Borges (2019) nos fala sobre essa comparação entre uma psicanálise que produz verdades e outra que se mantém em desdobramento: "Tomada como bandeira de ordem, faz proliferar as práticas fascistas e, tornando-se um psicanalismo - como mais um dos exercícios de poder e verdade das sociedades capitalísticas -, faz com que nos afastemos do campo sempre inaugural da teoria, que é a clínica.” (Borges, 2019, p.55).

Assim sendo, acreditamos que para pensar uma clínica contemporânea é preciso explorar os acontecimentos que permeiam a relação analítica, mas entendendo que qualquer definição que possa ser feita deve ser aceita como abertura e não como resolução de problema. É interessante pensar que mesmo o objetivo de falar em uma clínica contemporânea nos escapa. Durante a presente pesquisa fomos, enquanto humanidade, acometidos pela pandemia do vírus COVID-19, o que levou grande parte dos consultórios para um novo dispositivo. Nesse sentido, o que chamávamos de contemporâneo um ano atrás talvez já não caiba hoje. Interessante, porém, que este exemplo nos serve para ilustrar o que estamos aqui considerando um pilar da clínica hoje: a possibilidade da clínica de se adaptar quando apoiada na ideia de um manejo mais criativo - no sentido de criação - do que científico ${ }^{74}$.

Essa aparente digressão ganha corpo quando aplicamos esta compreensão do que seria o movimento psicanalítico à técnica em si. Como vimos, a partir do

\footnotetext{
${ }^{74}$ Aqui referimos a Birman (2014) quando usa primeiro Canghuilhem (1968) para afirmar que no discurso da ciência há sempre "um determinado objeto teórico (que) remete para um campo conceitual específico e determinado" (Birman, 2014, p.82), e depois a ideia de paradigma científico de Kuhn (1976), segundo a qual as revoluções científicas ocorrem em função de um processo de responder a perguntas específicas e depois refutá-las. Incluímos nessa lógica o discurso médico, que pretende dominar fenômenos, explicar e manipular sintomas. A psicanálise não opera segundo este discurso mas cria um discurso próprio. Segundo Birman (2014): "O discurso freudiano realizou esta crítica (ao discurso da medicina científica) desde o seu início no final do século XIX e a manteve posteriormente como tal, sem qualquer reformulação quanto a isso" (Birman, 2014, p.87).
} 
caminho aberto por Ferenczi passa a se pensar um analista que se define sobretudo pela sua possibilidade de sentir com, que está - apoiado sobre um conhecimento teórico e sobretudo por sua análise pessoal - presente e indo ao encontro do analisando sem um lugar pré-definido. As antigas referências que definiam a posição do analista deixam de ser suficientes e, por isso, ele precisa aprender a "percorrer o sensorial sem temê-lo, fazendo dele matéria-prima para modalidades subjetivas que vão, num movimento de apropriação do sentir, criando seus contornos próprios" (Gondar, 2019, p.9). O que Gondar nos diz ao abrir o livro "A clínica contemporânea e o abismo do sentido" (Borges, 2019) é que quando a fala deixa de ser instrumento suficiente para o trabalho psicanalítico o analista há de criar outras formas de intervenção. A associação livre e a atenção flutuante evidenciam sua insuficiência e exigem do analista uma postura outra. Seguimos na fala de Gondar:

Se determinamos o lugar desde o qual a experiência clínica se dá, acabamos nos afastando dela. Talvez sejamos mais fiéis à experiência analítica justamente quando abrimos mão de nossos referenciais teóricos e clínicos e nos desterritorializamos, colocando nossos conceitos em suspensão para encarar, sem tapete sob os pés, o caráter contigente e afetivo do encontro. (Gondar, 2019, p.11)

A questão para a qual devemos agora prosseguir é: o que da contemporaneidade convocou, ou melhor, evidenciou, esse aspecto afetivo da clínica?

Desde 1914 vemos em Freud uma especial preocupação com a instância egóica do funcionamento psíquico até então percebida de forma reduzida, associada sobretudo aos processos conscientes. Na medida em que começa a se pensar esse Eu não como estado vigil mas como algo a se alcançar, algo que precisa ser construído, torna-se necessário também endereçar os possíveis fracassos deste processo. Entretanto, Freud não se ocupa integralmente desta questão, privilegiando sempre o desenvolvimento sexual ao pensar os processos psíquicos. Os outros autores aqui trabalhados, entretanto, deram destaque ao narcisismo em sua obra, entendendo ser este um processo central para a compreensão do funcionamento psíquico, sobretudo o não neurótico. E aqui entra um ponto para nós medular. Além da questão da relação clínica já aludida, há também a percepção de que o sofrimento neurótico, marcado pelo conflito, não é 
o que mais marca o sujeito contemporâneo mas sim um sofrimento referido ao fora, ou melhor, que se dá na relação do dentro com o fora, na apresentação de si para o mundo, na continuidade do ser que vai de encontro ao outro, na fronteira. Percebemos, portanto, que o sofrimento tipicamente contemporâneo fala da relação do Eu com os objetos do mundo e, nesse sentido, a relação paciente analista torna-se campo de pesquisa privilegiado. Herzog e Pacheco (2014) falam sobre isso recorrendo a Birman75 (2014):

Segundo o autor, o sofrimento na contemporaneidade não se apresenta com as mesmas características e signos apresentadas nos tempos iniciais da psicanálise, pois a conflituidade psíquica não se sustenta de forma interiorizada, mas de forma exteriorizada. Este processo revelou que a figura do infantil não é mais de 'sua majestade o bebê', pois a contemporaneidade teria produzido uma perda do investimento narcísico fundamental. (Herzog; Pacheco, 2014, p.15)

Uma das ideias trazidas por estes autores é de que, diante este tipo de sofrimento marcado por uma carência da função de amarração de narcisismo, uma insuficiente integração egóica, uma relação conturbada entre o reconhecimento de si e o fora, a primeira função do analista seria mais de síntese do que de análise. Remetendo ao texto de Freud (1937b) "Construções na análise", Herzog e Pacheco (2014) defendem que muitas vezes o trabalho será menos o de desconstrução - como seria no caso de um atendimento neurótico, cujas ideias são fixas e enrijecidas - mas de construção. Segundo as autoras haveria, antes de tudo, a necessidade de organizar os fragmentos. Para isso seria uma postura mais adequada do analista a de afirmar do que perguntar. Importa testemunhar a existência do paciente de forma contínua, o ajudando a construir uma história pessoal, um Eu com mais pontos de referência.

Ideia semelhante é apresentada por Birman (2014) quando, ao abordar em seu artigo a questão do lugar do analista na atualidade, diz que a nítida transformação ocorrida na clínica se comparada aos anos 80 se torna evidente pelo surgimento de novas modalidades de sofrimento, sofrimentos estes que colocam o registro do olhar ao lado do registro da escuta no campo psicanalítico. A hipótese vai no sentido de afirmar que essa necessidade do olhar do analista se dá em 
função de um narcisismo marcado negativamente, ou seja, mais por sua ausência do que sua presença. Ele diz: "Portanto, o mal-estar na atualidade se enuncia nos registros do corpo, da ação e da intensidade, com pequena índice de interiorização, evidenciando ainda, em contrapartida, nesta exteriorização do conflito, o desinvestimento correlato que ocorreu nos registros do pensamento e da linguagem" (Birman, 2014, p.91). E continua afirmando que neste contexto a posição do analista pode ser associada a uma "restauração narcísica do sujeito" (Birman, 2014, p.91).

$\mathrm{Na}$ medida em que seguimos veremos que esta posição que passa a ser incorporada ao repertório técnico do psicanalista se assemelha, em muitos aspectos, ao que se entende como sendo a função subjetiva da mãe em relação ao seu bebê no início da vida. É nesse sentido que vemos nos teóricos afins desta ideia uma teoria que, enquanto muito clínica, em seu aspecto mais descritivo está sempre abordando os primórdios da vida e os primeiros encontros com o meio. Entretanto, devemos afirmar que não entendemos que a relação paciente analista deva reproduzir ou atualizar ou substituir aquela vivida pelo indivíduo com sua mãe. Mas nos aproximamos do autor americano Thomas Ogden quando ele fala da relação clínica em termos de um "momento presente do passado" (Ogden, 1994/2018, p.61). Parece mais interessante pensar a clínica atual enquanto espaço que potencializa a vivência de experiências primitivas do corpo e que, se o analista vai ao encontro do paciente, despido de qualquer pretensão diagnóstica ou identitária, emerge então um nível de relação que permite um campo de produção de vida (Borges, 2019).

A psicanálise de 1900, que nasce voltada para o passado, nos parece hoje ser levada para um lugar de pensar o constante presente na clínica. Se tomamos a noção de saúde em Winnicott, à qual podemos associar as ideias de uma continuidade do ser e de um sentimento de se viver à própria maneira, sobressai a importância do sujeito poder surfar no devir da vida e numa vida que se reconhece enquanto própria. $\mathrm{O}$ recordar, o preenchimento das lacunas mnêmicas, primeiro objetivo da terapia psicanalítica, perde seu lugar e, com o entendimento de novos objetivos, surgem novos pilares técnicos. Diante deste cenário pensamos que o 
objetivo de uma suposta clínica contemporânea seria o de criar um ambiente onde seja possível ir ao encontro do paciente e, a partir não só do que se verbaliza, mas do que se pode compreender pela atmosfera desse estado compartilhado, criar contornos para o sofrimento apresentado sem, entretanto, sair da fronteira. Segundo Gondar (2019) o trabalho a ser priorizado pelo analista é de encontrar o paciente e ser por ele afetado e, pro paciente, o que se pode obter da clínica é uma “apropriação do corpo, do sentir, da realidade do mundo e de suas limitações" (Gondar, 2019, p.11).

Em uma tentativa de ilustrar clinicamente o que estamos descrevendo apresento um breve relato sobre um atendimento infantil. Após já algum tempo de atendimento, a paciente de 4 anos que era por mim atendida em uma instituição passa a se recusar a ir para a sessão. Durante meses fui ao seu encontro no mesmo dia e horário sem conseguir levá-la para a sala de atendimento uma só vez. Vezes ela chorava ao me ver, vezes se escondia e se quer podia me olhar, vezes apenas me dizia, "hoje não quero". Eu respeitava esse limite e, com muitas inseguranças, seguia retornando no horário combinado. Um dia, sem mais explicações, ela veio para a sessão e nunca mais se recusou.

É claro que muitos outros elementos seriam importantes para um maior desenvolvimento do caso mas trago essa vinheta com o intuito de apreciar a qualidade particular do encontro analítico. Há algo que se passa, e que não pode ser desconsiderado, que não se dá pela fala e nem mesmo por qualquer outra forma de comunicação na sessão, mas que atravessa marginalmente a relação. Trata-se de uma linguagem mais discreta, menor, que na clínica contemporânea ganha notoriedade na medida em que os sofrimentos, associados às vivências narcísicas, falam do $\mathrm{Eu}$, da imagem, do corpo e menos dos conflitos em torno do desejo - como se vê no discurso neurótico. Borges (2019), ao pensar o conceito de falso self, nos presenteia com a seguinte imagem: "Entre a casca e o cerne, a ancoragem se daria na casca, espaço desencarnado" (Borges, 2019, p.27). Nesse sentido, caberia à experiência analítica prover um suporte para preencher esse corpo que se constituiu voltado apenas para fora, a partir do que o outro vê mais do que a partir do que se experiencia sensorialmente. Aqui sou remetida a um 
paciente que, ao ser perguntado sobre a própria percepção de uma situação, diz que acreditar nisto seria da ordem da metafísica, da religião.

Nota-se que nessa tentativa de apresentação do que compreendemos como sendo a clínica contemporânea alguns aspectos sobressaem. Estamos a todo tempo falando do campo transferencial que inclui o analista e este se observando enquanto participante daquele processo, o que nos levará a explorar a questão da contratransferência. Quando exaltamos esse fator o fazemos por acreditar que tem algo que se dá na atmosfera e não só na fala e, nesse sentido, estamos falando de uma qualidade de experiência primitiva - como vimos em Balint ao falar da "falha básica". Adentrando este campo somos levados a pensar o corpo e o manejo como balizadores do trabalho e os estados regressivos como acontecimentos que se dão ao longo do processo e que, se percebidos e adentrados pelo analista, permitem acesso a, segundo Bollas (1987), uma faceta poética e sensorial da experiência que seria importante para a compreensão da subjetividade do paciente que vai além da palavra.

\section{2 \\ A contratransferência como eixo técnico}

Ao falarmos da questão da contratransferência inevitavelmente endereçamos concepções contraditórias no movimento psicanalítico. Talvez seja possível dizer que, ao longo do primeiro século da psicanálise, as questões acerca deste tema tenham sido as mais frequentes causas de desavenças teóricas. Isto porque este conceito, se meramente aceito como pertinente e como algo a ser incluído no estudo psicanalítico, já alude a uma percepção da clínica que leva em consideração os afetos experienciados também pelo analista, ou seja, o afasta da antiga posição de neutralidade. Enquanto para alguns teóricos isso foi tomado como inaceitável, entendendo que qualquer sinal de afeto contratransferencial deveria ser trabalhado e evitado o quanto antes, para outros foi isso que permitiu a inclusão na clínica psicanalítica de uma nova gama de pacientes. Neste trabalho, como já deve ter ficado claro a essa altura, estaremos afinados com este segundo 
grupo e tentaremos agora ilustrar como esse aspecto da clínica é chave na contemporaneidade.

Talvez faça sentido começar apresentando algumas definiçõoes do que estaremos chamando de contratransferência. Paula Heimann, psicanalista alemã e referência no assunto, diz o seguinte sobre o conceito em seu texto "On countertransference" (1950 [1949]/2005): "Pelo propósito deste trabalho, estarei usando o termo 'contratransferência' para incluir todos os sentimentos experienciamos pelo analista em relação ao seu paciente" (Heimann, 1950 [1949]/2005, p.55). E, ainda: "Minha tese é que a resposta emocional do analista em relação ao seu paciente em situação analítica representa uma das mais importantes ferramentas para o trabalho. A contratransferência do analista é um instrumento de pesquisa sobre o inconsciente do paciente" (Heimann, 1950 [1949]/2005, p.56)

Já Bollas (1987) diz: “Uma posição constratransferencial é uma condição psicanalítica determinada pela nossa experiência enquanto objeto de uso do paciente dentro do campo transferencial" (Bollas, 1987, p.248), ou seja, uma posição adotada pelo analista que permite ao paciente usá-lo enquanto objeto de tal maneira que o analista é incluído em seu mundo subjetivo, tendo então acesso especial a ele. Em sua concepção Bollas prioriza a ideia de que o analista, se entregue ao processo analítico livre de suas próprias amarras identitárias, estaria sendo levado para o "idioma" ${ }^{76 "}$ do paciente e poderia, a partir desse estado, acessar sensações que não podem aparecer na associação livre. Extraímos de seu texto "Expressive Uses of the Countertransference: Notes to the Patient from Oneself" (Bollas, 1987) duas citações que nos parecem esclarecedoras: "É característico do nosso entendimento atual a respeito da transferência que uma outra fonte de acesso à associação livre do paciente é a contratransferência do analista, de tal forma que na busca pelo paciente devemos buscá-lo em nós mesmos" (Bollas, 1987, p.202); e "O estado contratransferencial mais comum é o de um não-saber-mas-experienciando. Eu sei que estou em um processo de

\footnotetext{
76 Vale destacar que "idioma" difere de "língua" na medida em que fala de uma linguagem desenvolvida de maneira natural e não enquadrada em um sistema. Acreditamos que ao usar essa palavra Bollas (1987) tentou enfatizar o aspecto singular e espontâneo do mundo interno de cada paciente. Não se trata de um sistema a ser compreendido mas de um funcionamento particular e não premeditado.
} 
experienciar algo, mas ainda não sei ao certo o que é esse algo, e possivelmente terei que sustentar esse não-saber por algum tempo" (Bollas, 1987, p.203).

No desenvolver de sua obra Bollas (1987) explicita que isso que se torna disponível através da contratransferência é o material infantil do sujeito. Trata-se da mesma forma de comunicação que um bebê tem com sua mãe e que na experiência analítica devemos lembrar que esta não é perdida mas perde lugar para a, como Ferenczi e Balint já teriam dito, linguagem adulta. Assim, através do uso do analista enquanto objeto, o paciente estaria expressando conteúdos de suas experiências primitivas que não puderam ser verbalizados na expectativa de que o analista, à maneira da mãe, possa transformá-los e então, de maneira cuidadosa, devolvê-los ao paciente que poderia então integrá-los. Segue uma passagem ilustrativa do caso que o autor chamou de Harold:

A partir da minha contratransferência eu 'sabia' quando ele estava em tal estado $^{77}$, e minha intenção enquanto escutava o conteúdo de sua narrativa era desnecessária, então eu me deixava apenas relaxar e, em tais momentos, eu apenas o contemplava. Eu não sei de que outra maneira descrever essa experiência se não dizendo que eu apenas pensava sobre toda sua vida, seu corpo e como ele aparentava. Eu apreciava esses momentos" (Bollas, 1987, p. 267).

A partir de situações como esta ele faz uma importante consideração sobre a técnica. $\mathrm{O}$ trabalho analítico não termina na experiência da contratransferência, resta saber ainda se, como e quando comunicá-la de volta ao paciente. Pensando nisso Bollas (1987) faz uma distinção entre um uso direto e um uso indireto da contratransferência. O primeiro tipo seria uma comunicação de seu estado enquanto objeto do paciente, já o segundo seria mais a exposição do material subjetivo de sua experiência. De todo modo o autor não deixa de enfatizar que não se deve fazer um uso indiscriminado de nenhum dos tipos. A conduta segue sendo aquela comum à técnica psicanalítica em todas suas facetas e fases: só se deve usar aquilo que for percebido como adequado às necessidades e possibilidades do paciente. A novidade talvez esteja mais no fato de que também este julgamento levaria em consideração a experiência subjetiva e sensorial do analista e não só seu saber ou sua escuta flutuante.

\footnotetext{
77 Aqui ele se referia a um estado que abordaremos mais tarde no capítulo que ele considerava uma
} "regressão ordinária". 
Em outro autor americano contemporâneo, Thomas Ogden, somos introduzidos, ao pensar a transferência e a contratransferência, a um novo conceito, este é, o "terceiro analítico". No primeiro capítulo de seu livro "Subjects in Analysis" (1994/2018), o autor nos explica o conceito traçando um paralelo entre a relação paciente-analista e autor-leitor. Ele diz:

Você, o leitor, deve permitir que eu te ocupe, ocupe seus pensamentos, sua mente, já que não tenho outra voz com a qual falar se não a sua. Se você está em vias de ler esse livro, você deve se permitir pensar meus pensamentos enquanto eu devo me permitir tornar-me seus pensamentos e, neste momento, nenhum de nós será capaz de tomar o pensamento como sua criação exclusiva (Ogden, 1994/2018, p.1).

A ideia é que em ambas as relações algo se cria a partir do encontro e que não pode ser reduzido a nenhuma das partes. Surge este terceiro que é diferente da transferência e da contratransferência na medida em que é algo que surge na interseção dos dois - "Em outras palavras, a transferência e a contratransferência refletem uma a outra mas não são imagens espelhadas" (Ogden, 1994/2018, p.5).

Não iremos aprofundar-nos neste conceito mas vale reter a noção, também presente em Bollas, de que há um trabalho do analista que envolve a possibilidade de "perder-se no outro". Na medida em que os pacientes contemporâneos muitas vezes não associam livremente o material para trabalho aparecerá sobretudo no uso que o paciente faz do analista e, para que isso não se perca, o analista deve estar entregue a uma escuta sensível que vai além da fala, deve escutar com o corpo, despido de seus contornos para ir ao encontro do paciente em um lugar "entre". Entendemos que este "entre" é o "terceiro" que Ogden coloca como resultante de uma dialética entre o par analítico, e o que Winnicott chamou de espaço potencial, melhor expresso pela ideia de paradoxo do que dialética. De todo modo, falamos de algo que se cria a partir do par mas não é nem um nem o outro e é percebido por ambos de maneiras distintas (Ogden, 1994/2018).

Ainda no mesmo livro, mas já em outro capítulo, Ogden afirma que não concebe a possibilidade de haver, no contexto analítico, um analisando dissociável de seu analista. Ao fazer tal afirmativa nos remete a Winnicott, que anos antes teria dito o mesmo sobre o bebê e sua mãe. E também a Heimann (1950 [1949]/ 2005), que nos lembra que ao falarmos do par paciente-analista estamos falando 
de uma relação, e uma relação exige necessariamente mais de um. Ou seja, devemos contemplar essa dupla sob dois aspectos: envolvem duas pessoas mas existe algo único que surge desse encontro específico. Compreendendo o poder da afirmativa do autor americano recorreremos a um de seus próprios casos clínicos como exemplo. Quem sabe a partir de um exemplo concreto a potência deste campo transferencial que surge na análise se torne mais palpável.

A paciente chamada de Ms. L78. inicia uma análise com Ogden em função de um quadro paralisante de ansiedade e depressão. Em um primeiro momento, chama a atenção do analista o fato de que, embora bem sucedida em seu trabalho como professora universitária, ela não parece obter nenhum prazer de tal ocupação nem de nenhuma outra função exercida em sua vida se não as atividades de pintar e ouvir música. Ao longo dos primeiros anos de tratamento o que o autor descreve são sessões de falas ininterruptas e repetitivas, deixando pouco espaço para o analista intervir. Este, por sua vez, se via perseguido pela ideia de um possível sadismo seu por não participar do atendimento, deixando a paciente falar de maneira solitária. Em dado momento, Ogden percebe que o conteúdo das histórias contadas pouco importam, trata-se mais de uma questão rítmica, como histórias que crianças pedem para dormir, do que uma narrativa a ser compreendida e penetrada. $\mathrm{O}$ falar na presença de alguém que apenas a escutava funcionava como atividade apaziguadora, bem como o pintar e ouvir música.

Selecionamos este exemplo por acreditar que nele fica evidente a possibilidade de um trabalho analítico pouco incluir o conteúdo verbalizado. $\mathrm{Na}$ escrita do caso nos deparamos com poucas passagens sobre o que a paciente dizia, o destaque é dado à forma como ela dizia e às sensações e aos pensamentos do analista ao escutá-la. O "terceiro" aparece na medida em que não se trata nem de um processo intrapsíquico da paciente, de um conteúdo que em sua repetição é marcado por uma resistência, nem de uma transferência e contratransferência separáveis - já que a compreensão de Ogden não vai por exemplo no sentido de afirmar um isolamento vivido pela paciente que o faz experienciar essa sensação na medida em que não o envolve em sua fala contínua e massante. $\mathrm{O}$ que se

78 Caso apresentado no capítulo "The analytic third: working with intersubjective clinical facts" do livro "Subjects of analysis" (Ogden, 1994/2018) 
apresenta é um funcionamento que envolve e depende dos dois mas que não pertence à experiência subjetiva de nenhum dos dois enquanto sujeitos distintos. Nas palavras do autor:

O analisando não simplesmente fala com o analista (ou com si mesmo) sobre as formas pelas quais ele cria suas experiências; ao invés disso, ele contribui para uma construção intersubjetiva dentro do setting analítico que dá corpo à forma e ao modelo da natureza do campo psíquico no qual o paciente vive (ou fracassa em fazer viver). Invariavelmente, o analista inconscientemente participa na criação dessa construção intersubjetiva que se dá no setting analítico. É em parte através dessa avenida (isto é, pela análise da contratransferência) que o analista ganha acesso à natureza dos estados de existência que compõem a matriz do mundo interno do paciente. (Ogden, 1994/2018, p.164) ${ }^{79}$

Segundo Minerbo (2020) temos na teoria de Ogden uma importante referência a Bion na medida em que concebe o campo transferencialcontratransferencial como "unidade indissolúvel formada pelo psiquismo do paciente e do analista" (Minerbo, 2012/2020, p.154). Fica evidente nos autores selecionados uma noção básica de que incluindo a contratransferência como eixo técnico topamos sempre com formas primitivas de expressão. Quando nos vemos retornando a Bion e Winnicott percebemos que o que está em jogo é sempre uma função materna do analista que, permitindo a criação de uma atmosfera na qual pode se perder com o par, facilita a construção de um campo de criação. Heimann (1950 [1949]/2005) defende não ser suficiente considerar a contratransferência como parcela da relação analítica, é preciso percebê-la em seu potencial criativo, como uma criação do próprio paciente.

Ainda no ínicio do capítulo usamos Birman (2014) para afirmar que o malestar na atualidade se materializa nos registros do corpo, da ação e da intensidade. Ora, estes não são capturados pela dinâmica de fala e escuta mas se manifestam em um outro formato de linguagem que é apreendido na análise da contratransferência - considerando a experiência sensorial do analista - e não na escuta flutuante enquanto instrumento isolado. Borges (2019) descreve tal fenômeno da seguinte maneira:

${ }^{79}$ Grifo do original 
Assim, a ideia seria orientar o processo transferencial (e contratransferencial) para um lugar atravessado pelas pequenas percepções, pelas percepções dos micromovimentos que se dão no interior de um corpo e que se expressam nesses atos performáticos do bebê. Um espaço entre, uma percepção que se dá no estado de presença ${ }^{80}$ (Borges, 2019, p.186).

A exemplo trazemos mais uma passagem de uma vivência clínica pessoal que se deu recentemente. Importante dizer que trata-se de um paciente que comecei a atender após ajudá-lo em uma situação na rua. A relação transferencial é aberta por uma situação na qual "o salvo" de algo após perceber em seu corpo um pedido de ajuda. Os atendimentos começam de forma intensa, sou constantemente buscada fora das sessões e o vínculo se estabelece muito rapidamente. Contratransferencialmente me sinto constantemente irritada com as demandas excessivas e o sofrimento que me parece exagerado. Me pego constantemente me perguntando se o paciente é um adolescente mimado ou um bebê desamparado, fico presa a esta questão. Acabo fazendo uma aposta na hipótese do bebê e, na medida em que desapego do conteúdo de suas queixas e me entrego a um cuidado mais atento e ritmado, ele chega um dia para a sessão e diz que lembrou de algo que o ajuda a controlar seus ataques de ansiedade: chupar pirulito. A partir deste dia, abre-se um novo caminho. Passo a ir ao encontro deste bebê que muito chora, não deixa a mãe dormir, precisa de chupeta e continuidade no cuidado e assim o tratamento tem uma grande virada.

Acreditamos que este relato pode ajudar a ilustrar como na clínica atual a participação do analista muitas vezes não será convocada à fala do paciente mas à forma pela qual se dá aquela relação. O que pôde aparecer no caso narrado foi que o conteúdo das queixas e dos pedidos de ajuda não eram tão relevantes mas sim sua constância e seu apaziguamento via corpo, via olhar. Minha irritação por não extrair nada daquele discurso monótono acabava repetindo os cuidados pouco atentos que marcavam a infância e juventude daquele homem, coisa que só vim a saber mais sobre após a experiência narrada. Não era sobre eu escutá-lo chorando ou sobre o por que chorava mas sobre a sutileza da percepção de que não era choro de birra mas de desamparo.

\footnotetext{
${ }^{80}$ Grifo do orignal
} 
Na medida em que passamos a explorar essa linguagem menor que se dá na relação paciente-analista e que postulamos haver nos sofrimentos contemporâneos uma precariedade narcísica, nos vemos ser constantemente referidos à questão do corpo. Como já vimos sobretudo na teoria winnicottiana, o processo de tornar-se corpo, de integrar-se enquanto sujeito encarnado, é um que pode fracassar em diferentes níveis. Na clínica contemporânea isso se torna evidente. Através do campo transferencial-contratransferencial essas sutilezas ganham possibilidade de expressão e seguiremos explorando como, através do manejo, elas podem ser ampliadas. Mas primeiro nos parece importante darmos atenção especial a isto que estamos chamando de corpo na psicanálise atual.

\section{3}

\section{O que sabe um corpo?}

Partiremos da ideia que de alguma forma se apresenta em Freud mas é mais desenvolvida em Ferenczi de que há coisas que o corpo sabe que o psiquismo desconhece. Ou melhor, há um psiquismo que se manifesta no corpo e apenas ali; não apenas por ser inconsciente mas por não ser sequer representação psíquica. Parece empiricamente inegável o fato de que, enquanto indivíduos dotados de um corpo, carregamos marcas e memórias que não passam pela esfera da representação. Como Borges (2019) chama há um "saber-do-corpo" que é frequentemente negado em prol de uma concepção que prioriza o cognitivo, a memória e o conhecimento via percepção.

Se levamos em conta a psicanálise clássica cabe dizer que, embora ela tenha olhado para o corpo, ao considerar o sintoma histérico a resultante de uma operação entre representações pode ser enquadrada neste grupo que negligencia o lugar do corpo como órgão de conhecimento. Ao corpo fica reservada a ideia de área de superfície ou destino mas raramente é percebido como campo de 
acontecimentos $^{81}$. A partir de uma pesquisa realizada pelo grupo NEPECC/UFRJ ${ }^{82}$ acerca do "sentimento da vergonha de si", apresentada no livro que leva o nome de "De Édipo a Narciso: a clínica e seus dispositivos" (2014), Sales e Herzog (2014) nos dizem: "Nesses atendimentos, diferentemente da descrição freudiana no âmbito da histeria, observamos que o corpo não comparece em sua dimensão erógena, mas sim envolto por questões que perpassam a sua unificação, apropriação e imagem" (Sales; Herzog, 2014, p.179).

Uma paciente com um histórico de internações por conta de uso de drogas me conta: "Lembrei-me da última vez que me vi no espelho, fazem 15 anos". Quando pergunto o que viu ela diz que não lembra. A sensação que tenho ao atendê-la é que o corpo existe apenas no prazer das drogas mas sem contorno bem delimitado, sem possibilidade de projeção no futuro. O prazer momentâneo é o que a encarna.

Retornamos agora ao contato de Ferenczi com os neuróticos de guerra, os portadores de tiques e mesmo algumas histerias. Dessa vivência passa a ser incluída na psicanálise um olhar que toma o corpo como pensante e afetado desde o princípio da vida, considerando até mesmo a experiência intrauterina. Essa concepção faz Borges (2019) falar em um "corpo-mente-psiquismo" que ela define como uma "força que, no encontro, por meio do ambiente, com os acontecimentos que se desenvolvem na experiência da vida, impulsiona em direção à construção de singularidade" (Borges, 2019, p.22). Ou seja, o que o teórico húngaro inaugura é que na constituição subjetiva também o corpo deve ter lugar de destaque uma vez que este nunca deixou de estar em contato com outros corpos, com o ambiente que constitui o sujeito. Ao estudar o trauma e as neuroses de caráter fica evidente que a tentativa de compreender o funcionamento psíquico do indivíduo referindo-o sobretudo à vivência edípica e tomando o corpo apenas em seu aspecto pulsional é limitada. Há de se atentar também ao sensível e

\footnotetext{
${ }^{81}$ Não podemos deixar de fora porém as contribuições freudianas de 1914, no texto sobre o narcisismo, e de 1920, em "Além do princípio do prazer". Ambas as obras são exemplos de momentos de sua teoria nos quais aparece um corpo que é contemplado para além de seu lugar erógeno. No primeiro caso se considera o processo de unificação corporal e no segundo, ao postular a ideia de pulsão de morte, aparece um corpo irrepresentável. Ainda assim, acreditamos que mesmo nessas obras o corpo aparece sempre referido ao pulsional, deixando de articular uma interação concreta entre o subjetivo e a matéria.

82 Núcleo de Estudos em Psicanálise e Clínica da Contemporaneidade
} 
concreto deste corpo e não só sua existência metafórica. Em comparação ao psíquico o corpo se apresenta como uma outra camada da subjetividade: "Colocam-se assim dois modos de subjetivar-se: na imaginação, o mundo das representações, as marcas do mundo exterior; e no sensível, o mundo da experiência, da matéria, do encontro dos corpos" (Borges, 2019, p.22).

A importância deste segundo modo ganha espaço na medida em que, na clínica contemporânea, aparecem sujeitos cujo sofrimento só pode ganhar expressão através desta forma de comunicação. Aquilo que na neurose aparecia na clínica através de representações - ainda que deslocadas, condensadas, omitidas, inventadas - nos sofrimentos não neuróticos se materializa de outra forma. Como vimos, é na contratransferência, a partir de um analista atento às pequenas percepções e que olha para si ao buscar o paciente, que sensações não representadas podem então o ser via o próprio analista. Nesta clínica o corpo ganha destaque como campo fértil de trabalho já que a denúncia é de sua fragilidade, sua descontinuidade, como Gondar (2014) coloca, sua existência paradoxal, já que apresenta uma tendência que vai no sentido da unificação e outra no sentido da fragmentação. Ao usarmos as noções de unificação/ fragmentação devemos entender que falamos de, remetendo novamente a Borges (2014), um “corpo-mente-psiquismo" - esta é a unidade em questão.

Agora que enfim falamos dos sofrimentos contemporâneos, pode ficar claro o porque do percurso pela teoria do trauma em Ferenczi. $\mathrm{O}$ recalque, “operador psíquico fundamental” (Gondar, 2014) da neurose, não é o que marca a clínica na atualidade. O lidar com o paciente não aponta para um conflito da ordem do desejo mas para uma questão de ritmo, tato e presença. Nesse sentido o que se apresenta enquanto mecanismo em destaque é a clivagem. "Ora, a clivagem não incide sobre representações inconciliáveis com o eu, como o recalque; ela age no plano do eu, conduzindo a sua fragmentação e até mesmo à pulverização do eu" (Gondar, 2014, p.120) - e este eu inclui o corpo.

Assim, na medida em que o que está em questão são pacientes cujos sofrimentos aparecem por meios que escapam a representação, o antigo modelo da interpretação deixa de ser prioridade e o papel do analista implicará, sobretudo, 
um manejo. Este manejo se aproxima do que descrevemos mais detalhadamente no capítulo que inclui o autor Winnicott, retomaremos esta questão em seguida. Mas no que diz respeito o corpo cabe fazer ainda uma diferenciação entre uma linguagem corporal e aquilo que estamos falando. Quando falamos de uma atenção do analista que vai para além da escuta e inclui o registro do olhar não queremos dizer que o trabalho passa a ser o de uma atenção minuciosa voltada para o corpo, os gestos e os movimentos do analisando. $\mathrm{O}$ corpo que está em questão é um corpo imanente, que se produz no encontro com o analista através da experiência sensorial. É, na verdade, aquela relação intersubjetiva, e que não é apenas anímica mas também corpórea. A própria distinção cartesiana entre psique e soma deixa de caber, como nos lembra Rozenthal (2014): "É preciso fazer a ressalva de que, considerando-se a alternativa da imanência, a própria linguagem nos obriga à imprecisão, posto que neste caso não haveria duas entidades - corpo e subjetividade -, mas somente o processo imanente de subjetivação" (Rozenthal, 2014, p.38).

A complexidade do corpo na clínica, esta clínica que se atualiza incessantemente, e que é também a vida, parece ser a de que o sujeito deve, ao mesmo tempo, seguir em devir e se identificar enquanto unidade constante. A proposta dos autores que viemos abordando indica que, assim como o bebê, o paciente pode, a partir da relação, integrar suas experiências de forma que constituem um eu que sustenta sua existência mesmo na intensa transmutação da vida.

Retomando o que vimos a respeito da contratransferência, falamos deste corpo que se produz na relação entre paciente e analista, à maneira do ocorrido entre mãe e bebê. É inclusive em função deste paralelismo que, ao falarmos dos sofrimentos contemporâneos e ao julgá-los narcísicos, somos compelidos a pensar o corpo e o manejo maternal do analista. A partir da clínica, dos movimentos paradoxais, da falta de coesão subjetiva dos pacientes, se questiona a qualidade da vivência narcísica. Este eu que se coloca em questão nos obriga a voltar nossa atenção para o ambiente, para o corpo, para o manejo. 


\section{4 \\ Busca por contorno através do manejo}

São várias as opções de nomenclatura para casos da contemporaneidade narcísicas, limítrofes, borderline - e, embora não sejam nem em peso nem em essência a mesma coisa, se encontram em uma ideia: todas aludem diretamente à questão do limite. O corpo do qual viemos falando como noção independente do eu e independente do outro, se apresenta como problema central da atualidade. Fala-se em forma mais do que em conteúdo. Em espaço preenchido, em movimento e não direção, em intensidade. Se a neurose era a doença da representação, da cena que paralisa o corpo, das cadeias de ideias que imobilizam o obsessivo, a não-neurose de hoje fala de um corpo que se cria pra fora, que carece de amarras de seu conteúdo e por isso não pode existir enquanto unidade contínua e com história. Do julgamento externo, se adaptando ao ambiente, se constrói um eu, mas este eu é esvaziado de sentido próprio, de espontaneidade e de referências sensoriais singulares.

Essa descrição parece exagerada já que, sendo algo frequente nos consultórios, trata-se muitas vezes de condições absolutamente funcionais, entretanto, são vidas pouco identificadas, como vimos ao falar do falso self em Winnicott. Reina, mesmo quando não verbalizada, uma sensação de não se viver à própria maneira já que a montagem se deu para o fora.

O que nos parece mais interessante de se explorar porém, é a ideia de que a "solução", o objetivo da psicanálise, não seria o de se voltar para uma interioridade, resgatar o funcionamento neurótico do recalque que opera de forma intrapsíquica, mas o de criar a partir do cruzamento de limites. A proposta é extrapolar a interseção que se dá no encontro entre dois corpos e criar subjetividade a partir dessa zona transicional, sustentar o não-lugar de forma compartilhada até que seja possível existir e continuar existindo mesmo nele.

Talvez a clínica seja sempre uma interrogação sobre o lugar do analista e sobre os lugares em geral, interrogações provenientes de nossa sensação de estarmos sempre fora de lugar - e, nesse sentido, podemos aprender muito com os pacientes narcísicos. Tratando-se de clínica contemporânea, esse é o sentimento mais comum que ambos, paciente e analista, experimentam. Os 
sujeitos contemporâneos não possuem referências indentificatórias capazes de lhe proporcionar um lugar. Nós tampouco. Quanto mais determinamos o lugar a partir do qual a experiência clínica pode se dar mais vamos nos afastar dela, ao menos com esses sujeitos. Talvez sejamos mais fiéis à experiência analítica justamente quando abrimos mão de nosso referenciais teóricos e clínicos e nos deslocalizamos $^{83}$.(Gondar, 2014, p.132)

Parece interessante pensar que a própria condição do sofrimento contemporâneo, que denuncia as exigências do capitalismo, a falta de espaço para espontaneidade, cobra exatamente isso do analista. A antiga postura da escuta flutuante deixa de funcionar diante angústias não representadas e o que resta de terapêutico é mais a presença do que saber do analista. Em uma sociedade de pouca presença contínua, de pouca possibilidade para permanência em um nãolugar, é justamente isso que o setting pode oferecer. $\mathrm{O}$ enquadre psicanalítico perde notoriedade mas ganha força na medida em que pode prover aquilo que deixa de ser priorizado: o corpo, o subjetivo, a atenção aos gestos mínimos. Esta breve digressão pretende apenas aludir à atmosfera na qual vivemos para caracterizar a importância de uma experiência de manejo.

Já vimos neste trabalho do que falamos quando usamos o termo manejo. Com Winnicott nos aproximamos das noções de holding e handling, com Ferenczi exploramos o "sentir com" e com Balint abordamos o nível da falha básica. De uma ou outra maneira falamos sempre de uma postura do analista que se afina com uma frequência que vai além do que é dito e trabalha nas bordas. Embora a fala e a escuta ainda sejam as ações principais da cena analítica, em termos do que constitui uma sessão, o que se dá em termos de experiência para o par ali presente é inteiramente outra coisa. Na medida em que acrescentamos o corpo e expandimos o campo da transferência somamos a esta dinâmica formas de interação que não podem ser vistas nem verbalizadas.

O manejo interage diretamente com o ser pouco delimitado do paciente limítrofe da mesma maneira que o faz em relação ao bebê. O lactante, no seu explorar do mundo ao qual recém-chegou, precisa de uma mãe que se mantém alíienquanto suporte sem entretanto invadí-lo. É preciso, ao mesmo tempo, espaço e presença - condições que irão se alternar e mesmo coexistir de forma gradativa

83 Termo atribuído a Ana Accioly (2010) 
e delicada. Borges (2014) diz sobre o trabalho de manejo na clínica: "Este descontínuo-contínuo nos remete à questão do paradoxo que foi desenvolvido em muitas de suas (Winnicott) temáticas, resultando na ideia de que um processo de análise não é algo que caminha para uma cura, mas para a produção de possibilidades em sustentar a vida na sua complexidade paradoxal” (Borges, 2019, p.15). ${ }^{84}$

Repetidamente falamos portanto de uma condição específica do analista que é a de ir ao encontro do analisando, partilhar um estado. O analista deve sustentar um ambiente seguro enquanto se perde e se mistura no par analítico. Pensando a teoria winnicottiana, é a disponibilidade da mãe no início da vida do bebê que permite a ele uma inserção na temporalidade e a possibilidade de pensar como criação. O paciente que estamos tentando descrever como representante da clínica contemporânea carece desta experiência primitiva que lhe concedeu ferramentas subjetivas para criar e brincar na vida e, assim, espera desenvolver tal capacidade a partir do to trabalho analítico.

Se adentramos o perigoso campo de nomear sintomas contemporâneos encontramos sobretudo afetações em relação ao corpo, à imagem e ao tempo. O paciente anoréxico, os reféns do mundo fitness, os consumistas, os workaholics... Isso apenas para citar estereótipos mas sabendo que a experiência da qual falamos é algo de ordem mais sutil e de forma alguma devemos levar tais exemplos como diagnósticos. Trata-se, entretanto, de condições que extrapolam a fragilidade do eu e perdem a capacidade neurótica de se iludir com fantasias irreais. O quadro melancólico, por exemplo, é descrito por Pinheiro (1995a) como um marcado pela impossibilidade do sujeito de se projetar no futuro a partir de ideais bem como de se voltar ao passado e contar a história de um eu. História esta que o neurótico constrói de bom grado, a alterando à sua maneira ao longo do tempo, mergulhando em suas contradições como obra do recalque. Mas o sujeito da falha narcísica é um paralisado no tempo pois não pôde constituir-se enquanto ser que existe no gerúndio. Seguindo com Pinheiro (1995a) ela diz que "construímos o

${ }^{84}$ Grifo do original 
edifício narcísico para podermos um dia aceitar a castração" (Pinheiro, 1995a, p. 4), e continua:

A inserção no tempo , a dimensão de passado presente e futuro que nos dá a noção de vida como espaço de tempo que compreende do dia do nascimento até a data previamente ignorada da morte, essa temporalidade que traz embutida a finitude,a impotência, vem no duro pacote da castração, mas é aceita sob a condição de que o passado seja de plenitudes e no futuro haja a segurança da "felicidade". (Pinheiro, 1995a, p.4)

Essa passagem nos serve para pensar que o sujeito que não construiu o “edifício narcísico" de forma suficiente não pode acreditar nas ilusões acordadas dentre os neuróticos - que é claro, produzem sintomas - de que a vida é segura e infinita. A vida se dá em um presente constante mas que não é, entretanto, atribuído a uma vida na imanência, na espontaneidade, e sim paralisada. Retornando à ideia de manejo, entende-se que o trabalho é, portanto, o de construir história e construir corpo. Ora, parecem ser estas as ferramentas necessárias para se construir o edifício narcísico.

Levando em consideração esta tarefa analítica volta como essencial a postura descrita por Ferenczi, Balint e Winnicott na qual analista se disponibiliza enquanto ambiente confiável. Apenas assim, com um ambiente atento ao ritmo do sujeito, é possível facilitar um processo de produção de subjetividade. Através do olhar do analista o paciente aprende a enxergar com seus olhos, e pode deixar de se ver apenas enquanto reflexo.

A apresentação do mundo através da maternagem tem como condição de possibilidade uma gestualidade sensível, que se repete nos cuidados rotineiros, produzindo a experiência da continuidade e ao mesmo tempo introduzindo novos elementos. Esta apresentação do mundo que a mãe realiza cria ao mesmo tempo a estabilidade necessária para o contato com o diverso, e favorece a construção de dois tempos - o tempo da duração do mesmo e o tempo da diferença, da descontinuidade. (Borges, 2019, p.26)

\section{5}

\section{Estados regredidos: uma experiência sensorial}

Já introduzimos ao longo deste trabalho algumas definições para a ideia de regressão. Começamos vendo como Freud entendia o processo como um que ocorre internamente no aparelho psíquico e que, enquanto fenômeno clínico 
deveria ser evitado. A regressão estava associada à formação do sintoma e a técnica psicanalítica se voltava para a ideia de cura. A partir das inaugurações de Ferenczi apresentamos uma outra concepção na qual, a partir de um destaque dado ao ambiente e aos processos internos do analista, passa a se incluir a regressão como um processo intersubjetivo que possibilita avanços terapêuticos para um tipo de paciente cujos sintomas surgem do mecanismo da clivagem e não do recalque. Balint, bebendo dessa fonte, produz uma obra que se volta inteiramente para a relação entre paciente e analista e, a partir de tal enfoque, destingue a regressão em maligna e benigna. Ambas, entretanto, falam de um processo que trata de um estado compartilhado pelo par. A benigna idealmente propiciaria um novo começo, sendo considerada, portanto, terapêutica. Para ele esses momentos regressivos poderiam aparecer em qualquer tipo de paciente e mais de uma vez em uma análise. Por fim, vimos em Winnicott a ideia de regressão à dependência, que evidencia o paralelo entre a função do analista e a função materna. $\mathrm{O}$ setting, como o ambiente primitivo, tem o potencial de facilitar os processos de desenvolvimento e amadurecimento que permitem o sujeito ir ao encontro do mundo à própria maneira.

Após este breve resumo seguiremos na tentativa de explicitar o que estamos agora considerando um estado regressivo. Fizemos neste capítulo uma tentativa de delimitar pontos balizadores do que estamos chamando de clínica contemporânea para esclarecer a pertinência de se pensar a regressão. Falamos de contratransferência, corpo e manejo entendendo que estes são as pontas que somadas enlaçam a clínica de pacientes regredidos.

Como ficou claro desde o início a palavra regressão alude para uma ideia de retorno. Seja como for, isso é uma constante em todas as teorias aqui abordadas. Muda, entretanto, ao que, como e por que se retorna. Evitando mais digressões, endereçaremos essas questões sob o olhar da atualidade. Birman (2014) considerou que a conflituidade psíquica se dá hoje "num confronto direto face a face do sujeito com o outro, que se manifesta ainda numa relação de corpo a corpo do sujeito com o outro" (Birman, 2014, p.91). O que entendemos disso é que a antiga questão neurótica, do confronto entre censura e desejo, se viu 
deslocada para o corpo, para o eu enquanto possibilidade de existência e continuidade quando defrontado com o mundo. É evidente que a sociedade capitalista, do consumo, das redes sociais, traz o foco de luz para a identidade. Nessas condições, nos deparamos com sua fragilidade.

Mas mais do que isso, tentamos enfatizar como esse apontamento não pretende limitar a clínica contemporânea à ideia de patologias narcísicas. Sim, estamos inevitavelmente falando de sofrimentos da ordem do narcisismo na medida em que tratamos a questão identitária, constituinte, como medular, mas optamos por destacar como esse encontro do sujeito com o outro nos convida a pensar as fronteiras. É esse aspecto que tentamos aprofundar, a potência do entre no encontro analista-analisando. A questão que parece estar em jogo é a importância tanto clínica quanto política da clínica contemporânea não se definir enquanto lugar estático. Aqui focaremos porém em seu aspecto clínico, técnico.

Quando descrevemos ao longo do trabalho - através das abordagens de Ferenczi, Balint e Winnicott - o período primitivo da constituição subjetiva enquanto um que exige uma atmosfera específica de mistura entre bebê e mãe, ser e ambiente, já falamos desse estado primeiro que é o de um não-lugar. Tratamos dessa relação como uma que se define justamente pelo encontro não delimitado para que, dessa condição primeira, possa então surgir o sujeito integrado e desejante - nunca enquanto processo concluído mas em sua continuidade. $\mathrm{O}$ primeiro desejo é o de não-desejar, a onipotência segundo Ferenczi (1913a/2011), a dependência absoluta segundo Winnicott (1958/1996), a atmosfera harmoniosa do amor primário segundo Balint (1937/2015). Com suas diferenças, compartilham da percepção de que a primeira experiência de existência aponta para essa mistura na qual não se percebe o outro enquanto tal mas enquanto continuação de um si que também ainda inexiste. Eu e outro são ainda sensações não contornadas.

Nesse sentido, ao deslocarmos a vivência mãe-bebê para a clínica, percebemos como certas experiências subjetivas não podem ser acessadas senão pela via sensorial, ou seja, anterior ao verbal. Essas experiências não são representadas e, portanto, são trabalhadas através da relação e do manejo da 
mesma. Nesse estado de potência mas também de vulnerabilidade entendemos que o as construções se dão não por palavras e narrativas mas por contorno. E, para criar contorno, precisamos primeiro não tê-lo. A regressão enquanto fenômeno clínico seria a possibilidade de experienciar o que Borges (2019) chamou de abismo. Essa possibilidade não é proposta, não é buscada, mas sim percebida na relação analítica.

Nos apoiamos agora em Bollas (1987) quando fala em "regressões ordinárias". Ele nos apresenta momentos de silêncio, de transformação na tensão corporal durante a análise, que representam esses mergulhos na experiência sensorial da existência. Segundo ele ocorre de o setting analítico conter aspectos que convidam o analisando para este tipo de vivência e, como vimos em Balint e Winnicott, se há no sujeito essa busca esperançosa por um encontro reparador, por um ambiente suficientemente bom, a tendência é de que se possa percorrer este tipo de estado além da palavra enquanto vivência terapêutica. Dentre estes aspectos facilitadores Bollas destaca o sofá que envolve, a presença e a proximidade do analista, os 50 minutos de segurança e disponibilidade não partilhada do analista.

Todos esses fatores parecem apontar para condições espaço-temporais, para a possibilidade de afrouxamento, de desligamento das representações que nos rodeiam a todo momento. O silêncio é então destacado como consequência desse estar com o outro em segurança para perder-se em si. É claro que ainda pensamos no silêncio como resistência, diz Bollas (1987), "Mas o tipo de silêncio que é condição necessária para a regressão à dependência é de uma qualidade diferente. O silêncio se torna meio pelo qual se pode experienciar o ambiente de holding ${ }^{85}$ analítico". (Bollas, 1987, p.263)

Remeto agora a um exemplo pessoal recente. Em um atendimento online com uma menina de 11 anos ela, que costuma falar em um fluxo contínuo sem dificuldades, silencia. Percebendo a atipicidade daquele movimento, acompanho. Ficamos alguns minutos em silêncio até que ela interrompe dizendo que começou um diário e pergunta se pode me mandar fotos dele. Acredito ser possível associar

${ }^{85}$ Grifo do original 
essa passagem ao que Bollas definiu como um silêncio característico da regressão à dependência. No meu entendimento a partir do experienciar apenas estar comigo, mesmo que virtualmente, ela pôde fazer um mergulho e voltar, me ofertando ainda, a partir de um lugar de confiança, as palavras que não pôde dizer mas escreveu.

Quando falamos do silêncio parece que na verdade enfatizamos a não intrusão. O manejo desses estados regressivos é marcado sobretudo por uma entrega do analista. A atenção flutuante dá lugar a um estado ampliado, que pretende se deixar ir de encontro corpo a corpo, suspendendo as fronteiras subjetivas. Recorremos novamente a Borges (2019):

Assim, só uma empatia comparável da mãe na relação com seu bebê permite uma comunicação mais discreta, como são os sinais emitidos por um lactante. Dentro desta perspectiva um ato analítico passa a requerer, além de sua experiência, sua qualidade humana, sua arte, e um movimento em direção ao outro no reconhecimento de sua diferença, na medida em que solicita, entre outras coisas, uma abertura em direção ao outro, um encontro psicótico possível - conforme apontado por Ferenczi como condição de receptividade necessária aos processos primários do desenvolvimento. (Borges, 2019, p.16)

Esse encontro especial, característico das vivências regressivas, dariam chão para o sujeito desenvolver-se no encontro com o outro. Se Birman (2014) falou desse conflito da atualidade do encontro face a face, podemos considerar que o fenômeno das regressões em análise trariam a possibilidade de experienciar o desenvolvimento dessa capacidade a partir do manejo sensível do analista.

Ao tratarmos da necessidade desse encontro pensamos em certos aspectos específicos desse tipo de pacientes. Não queremos pensar em termos nosográficos e nem excessivamente assertivos mas sim em qualidades, em sensações. Nos aproximamos do que Winnicott (1960/2018) descreveu como falso self quando trazemos à tona aspectos como a rigidez, a falta de apropriação corporal e limitada capacidade de criar, brincar. E também do que Pinheiro (2014) descreve como sintoma melancólico, a dificuldade de se inserir no tempo, de se projetar enquanto ser que continua existindo. Fala-se em uma frágil certeza de si que podemos remeter à noção de clivagem, do traumático em Ferenczi. Independente de uma definição precisa de qual processo está em jogo, do que é esse paciente, nossa intenção é a de apresentar a regressão como estados vividos em análise que, se 
percebidos enquanto potência, podem ser benéfico para o tratamento. Não entendemos que a regressão define apenas um tipo de paciente mas é uma vivência comum a todos em maior ou menor intensidade, de uma ou outra maneira, e que explicita e colore o esboço do que é a clínica contemporânea.

Acreditamos que o conceito em si é tema controverso na psicanálise justamente por apontar dois aspectos que são para nós caros: 1- a relação intersubjetiva que vem como mais importante que os processos intrapsíquicos e; 2- a ênfase na experimentação enquanto valor clínico. A regressão enquanto fenômeno só pode acontecer se consideramos a contratransferência. Se pensamos o paciente enquanto sujeito independente, a regressão de fato volta para sua compreensão freudiana de processo intrapsíquico que responde a uma fixação. Mas preferimos trazer à tona a potência de se permitir um estado de não integração em conjunto. O par analista-analisando é o que faz uma análise, é o que cria campo para produção de subjetividade, é o que dá lugar para o que escapa. Citamos agora o artigo escrito por Peixoto Junior a partir de sua fala no encontro do Rio de Janeiro do Grupo Brasileiro de Pesquisas Sándor Ferenczi, ocorrido em novembro de 2019:

Partindo da reação contratransferencial, a análise da contratransferência proposta por Ferenczi não apenas reconhece a reação emocional do analista como elemento constitutivo do setting analítico, mas o encoraja a explorá-la como parte de sua contribuição ao processo terapêutico. No lugar do analista, que antes de tudo interpreta o mundo interno do paciente, destaca-se agora aquele que trabalha em conjunto com ele. (Peixoto Junior, 2020, p.91)

A experimentação nos remete novamente a Ferenczi, o enfant terrible que, como vimos, foi ao encontro de seus analisandos disposto a escutar suas demandas e não o contrário. Com essa inversão nasce uma perspectiva clínica que se baseia sobretudo na noção de que o papel do analista seria o de se permitir não ter papel fixo. A maior potência da clínica na contemporaneidade passa a ser a possibilidade de viver o afrouxamento para criar, para deixar nascer um gesto espontâneo em uma sociedade marcada pela rigidez, pela objetividade. Nesse sentido, os estados regressivos representam esse afrouxamento e a experimentação - associada à prudência, como nos lembra com precisão Peixoto Junior (2020) - é o que permite o analista emprestar seu corpo a esta vivência. Afinal, sem a entrega 
do analista, como vimos, nada acontece, a análise segue sendo a cura pela palavra como no início do século XX. Ainda com Peixoto Junior, exploramos a noção de experimentação proposta por Deleuze e Guattari em Mil Platôs (1980) como contraponto à clínica da “interpretação do fantasma”. Ele diz:

Eis então o que é necessário fazer, dizem os autores: instalar-se sobre um estrato, experimentar as oportunidades que ele nos oferece, buscar aí um lugar favorável, eventuais movimentos de desterritorialização, linhas de fuga possíveis, vivencio-las, assegurar aqui e ali conjunções de fluxos, experimentar segmento por segmento dos conjuntos de intensidades, ter sempre um pequeno pedaço de uma nova terra. É seguindo uma relação meticulosa com os estratos que se consegue liberar linhas de fuga, fazer passar e fugir os fluxos conjugados, desprender intensidades contínuas. (Peixoto Junior, 2020, p.88)

Ora, o que estamos propondo é que a clínica da regressão é uma clínica do sensível, da experimentação com prudência e do encontro. E, na medida em que falamos de uma clínica da contemporaneidade como uma que evidencia a necessidade do sujeito deste tipo de experiência, parece fazer sentido explorar o conceito de regressão aqui exaustivamente abordado. Queremos deixar claro, entretanto, que o trabalho de enquadrar o estado regressivo em um quadro ou vivência fixa trairia o que estamos tentando apresentar desse fenômeno. A intenção sempre foi a de pensar como o reconhecimento deste tipo de vivência serviria para ampliar a clínica e nunca limitá-la. A regressão como meio para novos começos.

Por fim, ainda uma última vinheta clínica de um paciente com o qual encontro foi motor para essa pesquisa. Falamos de uma criança de apenas 3 anos cujo tratamento foi marcado por uma profunda regressão à dependência. Com ressentimento de não poder narrar o caso em sua totalidade, seleciono um pequeno fragmento. A criança e eu subíamos uma escada até a sala de atendimento e, durante meses, a escada se tornara tarefa difícil e que às vezes chegava a tomar metade do tempo da sessão. A dificuldade se dava pelo fato de que o paciente se jogava e paralisava. Apesar de saber andar perfeitamente no enquadre da sessão essa habilidade de repente dissolvia e ele precisava de auxílio para sustentar o próprio corpo. A cabeça ficava mole, todos os membros pareciam existir independentemente, as ligas não mostravam estrutura. Cabia a mim unir os pedaços. 
Segurava seus fragmentos um por vez, narrando o que eu percebia e perguntando o que sentia. Aos poucos ele aprendia a engatinhar. Eu então ia ao chão com ele e juntos desbravávamos cada degrau. Apenas com algum tempo de muitas tentativas é que se tornava possível ficar de pé e andar. Esse processo se dava toda sessão por muitos meses até que um dia parou de acontecer. Ele já podia andar sozinho.

Esse atendimento foi atravessado por um profundo sentimento contratransferencial, não à toa o trago aqui agora. No chão com a criança eu tampouco sabia andar, precisava reaprender junto com ele. Perceber no meu corpo como se levanta uma perna, o quanto de força é necessário para sustentar um corpo. Para sustentar dois corpos. Como se sustenta um sofrimento de forma intersubjetiva? $\mathrm{O}$ trabalho analítico hoje parece se repousar sobre esse tipo de questão e é nesse sentido que percebemos nas vivências regressivas, que convocam o manejo - a maternagem - campos de criação do novo, criação de um si que pode continuar se criando. 


\section{6 \\ Considerações finais}

Após um longo percurso de investigação da teoria e técnica psicanalítica, iniciado nos primórdios da teoria freudiana para alcançar a clínica contemporânea, fomos confrontados com diferentes compreensões acerca do conceito de regressão - ponto do qual partimos. Falamos inicialmente das divergências explanadas por essa noção e acreditamos que, comparando o trabalho dos autores Freud, Ferenczi, Winnicott e Balint, estas se tornaram palpáveis.

Quanto mais exploramos o conceito, mais nos tornamos familiarizados com os aspectos por ele implicados. Ao abordá-lo em sua esfera relacional, tornou-se necessário pesquisar também o campo transferencial desbravando ainda outro conceito polêmico, o de contratransferência. O que o estudo da teoria ferencziana logo nos mostrou é que, na medida em que se toma a regressão como movimento direcionado ao momento primitivo da vida, no qual sujeito e ambiente se misturam de forma - como Balint diria - harmoniosa, o conceito exige um estudo da constituição subjetiva e da importância do ambiente na mesma. Assim, a aproximação da ideia de regressão acaba por trazer como consequência uma exploração dos primórdios da vida psíquica em uma esfera mais teórica, e do manejo do analista em uma esfera mais clínica. Entretanto, uma conclusão importante, é de que ambas são indissociáveis.

No primeiro capítulo do presente trabalho abordamos a teoria freudiana em seus diferentes momentos. Vimos como, em uma tentativa de decifrar e dissolver o sintoma neurótico, primeiro objetivo da clínica psicanalítica, o que sobressaiu foi um funcionamento econômico do aparelho psíquico, que precisou ser organizado segundo tópicas e dinâmicas referidas sempre ao pulsional enquanto energia vital. Essa ideia não é rejeitada ao longo do trabalho mas é ampliada na medida em que incorporamos a esse método terapêutico uma nova gama de pacientes. É através dos escritos de Ferenczi que vemos ser acrescida à leitura pulsional um aspecto ambiental. Somos obrigados a sair do lugar estabilizado de um analista que observa e interpreta os movimentos intrapsíquicos para acessar uma função necessariamente mais implicada. 
Uma relação que merece ser destacada é aquela desenhada entre os pacientes difíceis de Ferenczi e o surgimento de uma clínica que tem o manejo de estados regressivos como pilar. Ao acolher sintomas distintos dos neuróticos, o psicanalista húngaro percebe a necessidade de priorizar uma postura analítica que se apoia, sobretudo, na noção de tato. A fala e o material recalcado, antes matéria primordial do trabalho, na medida em que não são caraterísticos desse tipo de paciente dão lugar a vivências que se manifestam diretamente na relação com o analista. A demanda do paciente deixa de ser da ordem do conflito interno e passa a ser direcionada para o fora, para o ambiente que, no caso da clínica, se personifica no analista.

Lidando com pacientes cujos sofrimentos se manifestavam principalmente na esfera do ego, no que diz respeito a continuidade do eu e a confiança na própria existência, o papel da clínica passa a ser o de acolher a criança presente em todo adulto. Se deparando com um mecanismo de defesa distinto do recalque, a clivagem, que ao invés de censurar a própria experiência, a segrega, o húngaro passa a entender como terapêutica a provisão de um espaço confiável para a criação do próprio eu. A permissão para a regressão aos primórdios na segurança de um analista capaz de sentir com, nasce como ferramenta indispensável para essa nova classe de clientes da psicanálise.

Na medida em que seguimos com os autores Balint e Winnicott, torna-se evidente a influência do caminho aberto por Ferenczi na obra de ambos. Se a Ferenczi devemos pela experimentação que permitiu à técnica uma elasticidade, incluindo sofrimentos não neuróticos no campo da psicanálise, a Balint devemos pela minuciosa construção e descrição dessa clínica. Pesquisador cuidadoso, vimos em sua obra pontos essenciais para a compreensão de outras manifestações subjetivas. Acreditamos que sua coragem de seguir na esteira de Ferenczi e observar tão atentamente a influência das ações do analista sobre o paciente é essencial para compreender as relações contemporâneas nas quais o analista é extremamente convocado pelo analisando. Sua descrição das regressões malignas e benignas, na medida em que abordam de maneira honesta os perigos e 
potenciais dos fenômenos regressivos, abrem precedente para pensar a fundo o manejo de sofrimentos narcísicos.

Em Winnicott, há de ser destacada a inclusão do corpo e das sensações no material clínico. Nos parece que muito do que se pode pensar na clínica contemporânea sobre o ritmo e as pequenas percepções tiveram sua gênese no trabalho do autor britânico. A regressão em análise atinge aqui talvez sua descrição mais palpável. Somos levados a compreender que a experiência infantil segue marcada no corpo - no eu, no eu corpóreo - independente de qualquer compreensão no que diz respeito o pulsional e as representações. Muitas vezes na clínica estaremos lidando com uma esfera da experiência completamente além da palavra, ainda que esta esteja presente.

Essa breve digressão pelos autores percorridos culmina no que foi construído no último capítulo e que merece ser aqui integrado enquanto conclusão deste trabalho. A postura curiosa e acolhedora, presente em todos os autores apresentados, é o que faz da psicanálise uma clínica atemporal. Embora sua origem se atrele ao sintoma histérico, na clínica contemporânea já nos vemos muito distantes dos mesmos, e a integração à clínica, de outros tipos de sofrimento, demanda novas ferramentas técnicas, e é isso que a mantém viva. Nesse sentido, percebendo na atualidade sofrimentos que se voltam diretamente para o corpo, para o eu e para a relação com os objetos, somos obrigados a deixar de pano de fundo o estudo sobre o conflito neurótico para aproximarmo-nos dos estudos abertos por Ferenczi acerca do sofrimento narcísico.

É a partir da demanda dos pacientes atuais, que exigem um manejo mais fino, que nos vemos retomando as experiências regressivas como meios de acesso ao primitivo, campo carregado de marcas. A regressão, enquanto vivência que engloba os aspectos do sofrimento narcísico, se torna não só retorno, não só uma exploração clínica, mas um campo de permissão para uma experiência além da palavra. A regressão enquanto fenômeno é incluída na clínica contemporânea por ser aquilo que obrigatoriamente lança analista e analisando em um encontro de potência de vida. Na origem da psicanálise, buscava-se viver em ressonância com o próprio desejo. $\mathrm{Na}$ atualidade, parece carecer a possibilidade de viver em 
continuidade com o próprio ser, que antecede mesmo a esfera desejante. É, portanto, no âmbito primitivo do encontro que se torna possível construir sentido. Não pela palavra, mas pelo corpo, pela sensação, pela arte de viver enquanto eu sujeito de um mundo.

Partindo de um estudo mais teórico acerca do conceito, fomos convocados a mergulhar no contexto clínico. Essa trajetória nos evidenciou um aspecto da psicanálise que, embora tenha sido contemplado, incita para novas explorações. O fenômeno da regressão, na medida em que convoca o analista a criar uma nova postura, aponta para o caráter mutável da psicanálise, e esse nos interessa em especial.

Pensando uma clínica contemporânea, marcada pela inclusão do manejo como pilar, somos expostos a um aspecto da terapia psicanalítica que na verdade sempre esteve presente. Quando Ferenczi e os autores que seguem sua trajetória se dispõem a atender uma nova gama de pacientes e orientar uma técnica segundo os acontecimento daquela relação, eles na verdade repetem a postura freudiana característica do nascimento da psicanálise. Postura esta que marca uma busca por conhecimento através da relação, de forma que, ainda que se pretenda dominar os fenômenos, se aproximando de uma noção científica, tal objetivo é limitado pela impossibilidade de se isolar dois sujeitos em devir.

O fenômeno da regressão é um que coloca em evidência esse caráter instável da psicanálise. Essa pesquisa deixa a conclusão de que os movimentos subjetivos só podem ser percebidos em sua presença e sua atualidade. Uma tentativa de dominá-los e organizá-los enquanto uma cadeia de representações parece deixar de contemplar a esfera da subjetividade que é mais presente, mais viva. Aquilo que se apresenta no menor, na vivência que não pode ser narrada, parece ser a força de uma psicanálise que pode se manter atual.

Dessa conclusão aflora o desejo de seguir explorando justamente esse aspecto do campo psicanalítico, o de pensar a clínica atual justamente pelo o que, no encontro paciente-analista, se apresenta enquanto manifestação presente, afirmativa, corpórea e sensorial. A aposta vai no sentido de afirmar que a psicanálise se sustenta enquanto saber e método terapêutico por ir ao encontro do 
sujeito. Em uma sociedade tecnológica, positivista e cartesiana, o não-saber do analista, que trabalho sempre no campo da surpresa, do acontecimento, é resistência.

Assim, entendemos que a pesquisa acerca da noção de regressão ganha importância na medida em que joga luz sobre a potência do saber psicanalítico de constantemente se atualizar. Partindo da teoria para a clínica, para por fim entender que ambas não podem ser separadas, deparamo-nos com forças únicas da psicanálise. O manejo da regressão, a compreensão de uma linguagem que não a vigente (verbal), explana o a transgressão de uma psicanálise que pouco se define porque, como arte, surge na criação. 


\section{Referência bibliográficas}

Avello, J. (1998). Para leer a Ferenczi. Editorial Biblioteca Nueva.

Balint, M. (1992). The Basic Fault: therapeutic aspects of regression. Evanston: Northwestern University Press. (Original publicado em 1968)

Balint, M. (2015). The final goal of psychoanalytic treatment. In Primary love and psycho-analytic technique. Tavistock Press. (Original publicado em 1935)

Balint, M. (2015). Early developmental states of the ego In Primary love and psycho-analytic technique. Tavistock Press. (Original publicado em 1937)

Balint, M. (2015). Primary love and psycho-analytic technique. Tavistock Press. (Original publicado em 1952)

Birman, J. (2014). Um outro lugar para o analista. In Herzog, R; Pacheco-Ferreira, F. (Org.), De Édipo a Narciso: A clínica e seus dispositivos. Cia de Freud.

Bollas, C. (1987). The shadow of the object. New York Columbia University Press.

Bonaminio, V. (2011). Nas margens de mundos infinitos. Imago.

Borges, H. (2019). A clínica contemporânea e o abismo do sentido. 7 letras.

Borgogno, F. (2004). Uma contribuição de Ferenczi à psicanálise infantil: a pensabilidade do trauma e do traumático. In Psicanálise como percurso. Imago. (Original publicado em 1997)

Borgogno, F. (2004). A elasticidade da técnica como projeto e percurso psicanalítico de Sándor Ferenczi. In Psicanálise como percurso. Imago. (Original publicado em 1998)

Costa, J. F. (1995). Uma fonte de água pura. In Pinheiro, T. Ferenczi: Do grito à palavra. Casa do psicólogo. 
Ferenczi, S. (2011). Do alcance da ejaculação precoce. In Obras completas, Vol. I. Martins Fontes. (Original publicado em 1908)

Ferenczi, S. (2011). Transferência e introjeção. In Obras completas, Vol. I.

Martins Fontes. (Original publicado em 1909)

Ferenczi, S. (2011). O conceito de introjeção. In Obras completas Vol. 1. Martins Fontes. (Original publicado em 1912a)

Ferenczi, S. (2011). Sintomas transitórios no decorrer de uma psicanálise. In Obras completas Vol. 1. Martins Fontes. (Original publicado em 1912b)

Ferenczi, S. (2011). O desenvolvimento do sentido de realidade e seus estágios. In Obras completas Vol. II. Martins Fontes. (Original publicado em 1913a)

Ferenczi, S. (2011). Fé, incredulidade e convicção sob o ângulo da psicologia médica. In Obras completas Vol. II . Martins Fontes. (Original publicado em 1913b)

Ferenczi, S. (2011). Dois tipos de neurose de guerra (histeria). In Obras completas Vol. II. Martins Fontes. (Original publicado em 1916)

Ferenczi, S. (2011). As patoneuroses. In Obras completas Vol. II. Martins Fontes. (Original publicado em 1917)

Ferenczi, S. (2011). Psicanálise das neuroses de guerra. In Obras completas Vol. III. Martins Fontes. (Original publicado em 1918a)

Ferenczi, S. (2011). A técnica psicanalítica. In Obras completas Vol. II. Martins Fontes. (Original publicado em 1918b)

Ferenczi, S. (2011). Dificuldades técnicas de uma análise de histeria. In Obras completas Vol. III. Martins Fontes. (Original publicado em 1919)

Ferenczi, S. (2011). Prolongamentos da "técnica ativa" em psicanálise. In Obras completas Vol. III. Martins Fontes. (Original publicado em 1920) 
Ferenczi, S. (2011). Reflexões psicanalíticas sobre os tiques. In Obras completas Vol.III Martins Fontes. (Original publicado em 1921)

Ferenczi, S. (2011). As fantasias provocadas. In Obras completas Vol. III. Martins Fontes. (Original publicado em 1924a)

Ferenczi, S. (2011). Perspectivas da Psicanálise. In Obras completas Vol. III. Martins Fontes. (Original publicado em 1924b)

Ferenczi, S. (2011). Thalassa. In Obras completas Vol. III. Martins Fontes. (Original publicado em 1924c)

Ferenczi, S. (2011). Contraindicações da técnica ativa. In Obras completas Vol. III. Martins Fontes. (Original publicado em 1926)

Ferenczi, S. (2011). A elasticidade da técnica psicanalítica. In Obras completas Vol. IV. Martins Fontes. (Original publicado em 1927)

Ferenczi, S. (2011). A criança mal acolhida e sua pulsão de morte. In Obras completas Vol. IV. Martins Fontes. (Original publicado em 1929)

Ferenczi, S. (2011). Princípio de relaxamento e neocatarse. In Obras completas Vol. IV. Martins Fontes. (Original publicado em 1930)

Ferenczi, S. (2011). Análise de crianças com adultos. In Obras completas Vol. IV. Martins Fontes. (Original publicado em 1931)

Ferenczi, S. (2011). Confusão de línguas entre os adultos e a criança. In Obras completas Vol. IV. Martins Fontes. (Original publicado em 1933)

Freud, S. (1994). As neuropsicoses de defesa. In: Obras Psicológicas Completas de Sigmund Freud: edição standard brasileira. Vol. III. Imago. (Original publicado em 1894)

Freud, S; Breuer, J. (2010). Estudos sobre a histeria. Obras completas volume 2. Companhia das Letras. (Original publicado em 1895) 
Freud, S. (2017). A Intepretação dos sonhos. Obras completas volume 4. Companhia das Letras. (Original publicado em 1900)

Freud, S. (2016). Análise fragmentada de um caso de histeria (Caso Dora). In Obras completas volume 6. Companhia das Letras. (Original publicado em 1905a)

Freud, S. (2016). Três ensaios sobre a teoria da sexualidade. In Obras completas volume 6. Companhia das Letras. (Original publicado em 1905b)

Freud, S. (2010). “O Caso Schreber”. In Obras completas volume 10. Companhia das Letras (Original publicado em 1911a)

Freud, S. (2010). Formulações sobre os dois princípios do funcionamento psíquico. In Obras completas volume 10. Companhia das Letras (Original publicado em 1911b)

Freud, S. (2010). O uso da interpretação dos sonhos na psicanálise. In Obras completas volume 10. Companhia das Letras (Original publicado em 1911c)

Freud, S. (2010). A dinâmica da transferência. In Obras completas volume 10. Companhia das Letras (Original publicado em 1912a)

Freud, S. (2010). Recomendações ao médico que pratica psicanálise. In Obras completas volume 10. Companhia das Letras (Original publicado em 1912b)

Freud, S. (2010). O início do tratamento. In Obras completas volume 10. Companhia das Letras (Original publicado em 1913)

Freud, S. (2010). Introdução ao narcisismo. In Obras completas volume 12. Companhia das Letras (Original publicado em 1914a)

Freud, S. (2010). Recordar, Repetir e Elaborar. Obras completas volume 10. Companhia das Letras. (Original publicado em 1914b)

Freud, S. (2010). A pulsão e seus destinos. Obras completas volume 12. Companhia das Letras. (Original publicado em 1915a) 
Freud, S. (2010). Considerações atuais sobre a guerra e a morte. Obras completas volume 12. Companhia das Letras. (Original publicado em 1915b)

Freud, S. (2010). O inconsciente. Obras completas volume 12. Companhia das Letras. (Original publicado em 1915c)

Freud, S. (2016). Conferência XXII. Obras completas volume 13. Companhia das Letras. (Original publicado em 1916)

Freud, S. (2010). História de uma neurose infantil ("O Homem dos Lobos”) In Obras completas volume 14. Companhia das Letras. (Original publicado em 1918)

Freud, S. (2010). Caminhos da terapia psicanalítica. In Obras completas volume 14. Companhia das Letras. (Original publicado em 1919)

Freud, S. (2010). Além do princípio do prazer. In Obras completas volume 14.

Companhia das Letras. (Original publicado em 1920)

Freud, S. (2011). O Eu e o Id. In Obras completas volume 16. Companhia das Letras. (Original publicado em 1923)

Freud, S. (2014). Inibição, sintoma e angústia. In Obras completas volume 17. Companhia das Letras. (Original publicado em 1926).

Freud, S. (2018). Análise termináveis e interminável. In Obras completas volume 19. Companhia das Letras. (Original publicado em 1937a).

Freud, S. (2018). Construções na análise. In Obras completas volume 19. Companhia das Letras. (Original publicado em 1937b).

Gondar, J. (2019). Apresentação In Borges, H. A clínica contemporânea e o abismo do sentido. 7 letras.

Gondar, J. (2014). Um paradoxo nos sofrimentos narcísicos. In Herzog, R; Pacheco-Ferreira, F. (Org.), De Édipo a Narciso: A clínica e seus dispositivos. Cia de Freud.

Gurfinkel, D. (2017). Relações de objeto. Blucher. 
Heimann, P. (2005). On counter-transference. In About children and children nolonger. New Library of Psychoanalysis. (Original publicado em 1950[1949])

Herzog, R; Pacheco-Ferreira, F. (2014). Para introduzir o Narcisismo... cem anos depois. In Herzog, R; Pacheco-Ferreira, F. (Org.), De Édipo a Narciso: A clínica e seus dispositivos. Cia de Freud.

Minerbo, M. (2020). Transferência e contratransferência. Blucher. (Original publicado em 2012)

Medeiros, E. (2020). A problemática do trauma: aspectos teóricos e clínicos (Tese de doutorado). Pontifícia Universidade Católica do Rio de Janeiro (PUC-Rio).

Ogden, T. (2018). Subjects of analysis. Routledge (Original publicado em 1994)

Peixoto Junior, C. A. (2013). Michael Balint: a originalidade de uma trajetória psicanalítica. Revinter.

Peixoto Junior, C. A. (2020). Experimentação e prudência na clínica de Sándor Ferenczi. In Kuperman, D; Gondar, J; Canesin Dal Molin, E. (Org.), Ferenczi: Inquietações clínico-políticas. Zagodoni Editora.

Pinheiro, T. (1995a). Algumas considerações sobre o narcisismo, as instâncias ideais e a melancolia. Cadernos de Psicanálise, SPCRJ, v. 12, n. 15, p. 20-8, nov/ 1995.

Pinheiro, T. (1995b). Ferenczi: Do grito à palavra. Jorge Zahar Ed./Ed UFRJ.

Pinheiro, T. (2003). A escravidão do olhar. In Arán, M. (Org.), Soberanias Coleção Espaço Brasileiro de Estudos Psicanalíticos. Contra capa livraria.

Pinheiro, T. (2014). Histeria e falso self aproximações e diferenças. In Herzog, R; Pacheco-Ferreira, F. (Org.), De Édipo a Narciso: A clínica e seus dispositivos. Cia de Freud.

Pinheiro, T. (2016). Ferenczi. Casa do Psicólogo.

Pontalis, J-B. (1991). A força de atração. Jorge Zahar. 
Rozenthal, E. (2014). O ser no gerúndio: Corpo e sensibilidade na psicanálise. Cia de Freud.

Sales, J.L.; Herzog, R. (2014). O corpo em psicanálise: entre a fragmentação e a ilusórios unificação. In Herzog, R; Pacheco-Ferreira, F. (Org.), De Édipo a Narciso: A clínica e seus dispositivos. Cia de Freud.

Winnicott, D. (2018). Primitive emotional development. In Through paediatrics to psychoanalysis: Collected papers. Routledge (Original publicado em 1945)

Winnicott, D. (2018). Transitional objects and transacional phenomena In Through paediatrics to psychoanalysis: Collected papers. Routledge (Original publicado em 1951)

Winnicott, D. (2018). Metapsychological and clinical aspects of regression within the psychoanalytical set-up In Through paediatrics to psychoanalysis: Collected papers. Routledge (Original publicado em 1954a)

Winnicott, D. (2018). Withdrawal and regression In Through paediatrics to psychoanalysis: Collected papers. Routledge (Original publicado em 1954b)

Winnicott, D. (2018). Primary maternal preoccupation. In Through paediatrics to psychoanalysis: Collected papers.. Artmed (Original publicado em 1956)

Winnicott, D. (1996). A integração do ego no desenvolvimento da criança. In $O$ Ambiente e os processos de maturação: estudos sobre a teoria do desenvolvimento emocional. Artmed (Original publicado em 1962)

Winnicott, D. (1996). Comunicação e falta de comunicação levando ao estudo de certos opostos. In $O$ Ambiente e os processos de maturação: estudos sobre a teoria do desenvolvimento emocional. Artmed (Original publicado em 1963a)

Winnicott, D. (1996). Da dependência à independência no desenvolvimento do indivíduo. In O Ambiente e os processos de maturação: estudos sobre a teoria do desenvolvimento emocional. Artmed (Original publicado em 1963b) 
Winnicott, D. (1999). A comunicação entre o bebê e a mãe e entre a mãe e o bebê: convergências e divergências. In Os bebês e suas mães. Martins Fontes. (Original publicado em 1968) 